\title{
Nutrient Concentrations in Upper and Lower Echo, Fallen Leaf, Spooner, and Marlette Lakes and Associated Outlet Streams, California and Nevada, 2002-03
}

Open-File Report 2004-1333

Prepared in cooperation with

TAHOE REGIONAL PLANNING AGENCY

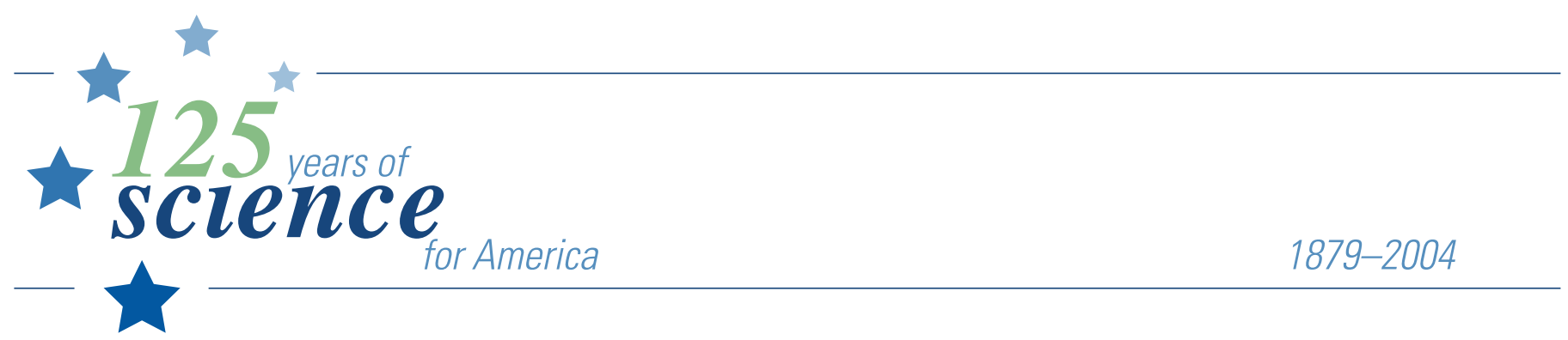

U.S. Department of the Interior U.S. Geological Survey 
(Back of Cover) 


\section{Nutrient Concentrations in Upper and Lower Echo, Fallen Leaf, Spooner, and Marlette Lakes and Associated Outlet Streams, California and Nevada, 2002-03}

by Michael S. Lico

U.S. GEOLOGICAL SURVEY

Open-File Report 2004-1333

Prepared in cooperation with the

TAHOE REGIONAL PLANNING AGENCY 


\title{
U.S. DEPARTMENT OF THE INTERIOR GALE A. NORTON, Secretary
}

\author{
U.S. GEOLOGICAL SURVEY \\ CHARLES G. GROAT, Director
}

Any use of trade, product, or firm names in this publication is for descriptive purposes only and does not imply endorsement by the U.S. Government

For additional information contact:

District Chief

U.S. Geological Survey

333 West Nye Lane, Room 203

Carson City, NV 89706-0866

Email: GS-W-NVpublic-info @ usgs.gov

World Wide Web: http://nevada.usgs.gov
For more information about the U.S. Geological Survey and its products:

Telephone: 1-888-ASK-USGS

World Wide Web: http://www.usgs.gov 


\section{CONTENTS}

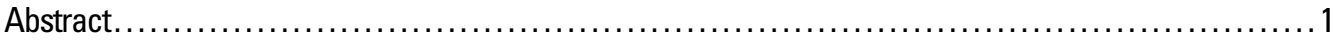

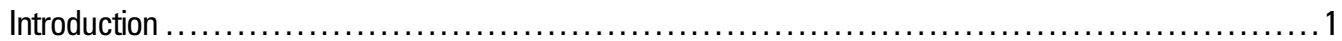

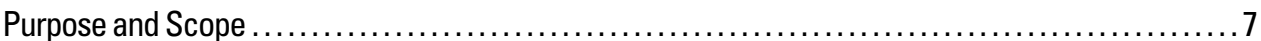

Previous Studies of Nutrient Concentrations in Lake Tahoe Basin Lakes ......................... 7

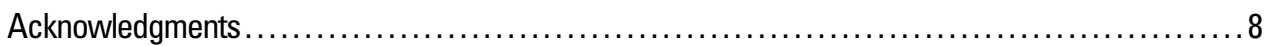

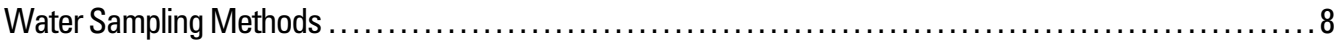

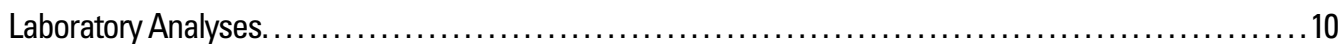

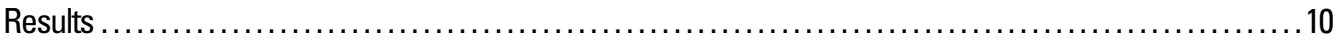

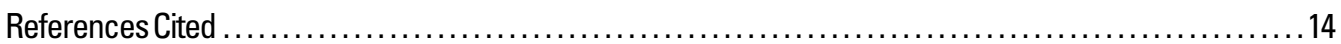

Appendixes:

A. Physical and chemical profile data collected from study area lakes, $2002-03 \ldots \ldots \ldots \ldots \ldots \ldots 31$

B. Nutrient concentrations in water samples and field data collected at study area

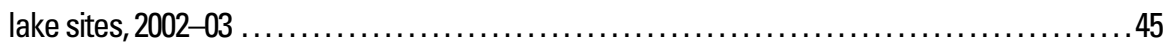

C. Nutrient concentrations in water samples and field data collected at study area

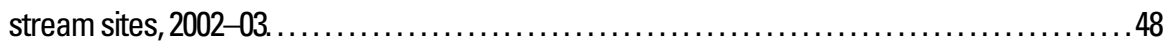

D. Nitrate concentrations determined using the Hydrazine method with pyrophosphate for samples collected from study area lake and stream sites after May 2003.

\section{Figures}

1. Map showing location of study area 2

2. Maps showing location of sampling sites in: $(A)$ Upper and Lower Echo Lakes,

(B) Fallen Leaf Lake, (C) Spooner Lake, and (D) Marlette Lake............................ 3

3. Photograph of summer homes along shore of Lower Echo Lake............................ 7

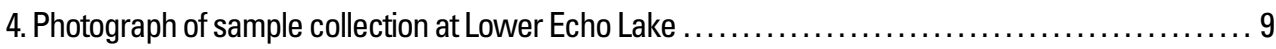

5. Graphs showing profiles of field measurements taken in (A) Upper Echo Lake near center (site 5), (B) Lower Echo Lake near center (site 2), (C) Fallen Leaf Lake near center (site 10), (D) Spooner Lake near center (site 14), and (E) Marlette Lake

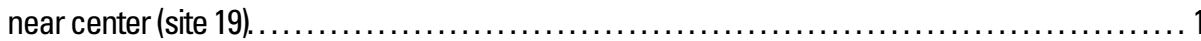

6. Boxplots showing the distribution of nutrient data from Upper and Lower Echo,

Fallen Leaf, Spooner, and Marlette Lakes: $(A)$ dissolved nitrate (sum of nitrate plus nitrite), $(B)$ dissolved ammonia, $(C)$ total Kjeldahl nitrogen (ammonia plus organic nitrogen), (D) dissolved orthophosphorus (soluble reactive phosphorus), $(E)$ total phosphorus, and $(A$ total bioreactive iron

7. Plots showing concentrations of nutrients in samples from Echo, Taylor, and Marlette Creeks: $(A)$ dissolved nitrate (sum of nitrate plus nitrite), $(B)$ dissolved ammonia, ( $C$ ) total Kjeldahl nitrogen (ammonia plus organic nitrogen), (D) dissolved orthophosphorus (soluble reactive phosphorus), (E) total phosphorus, and $(A)$ total bioreactive iron 


\section{Tables}

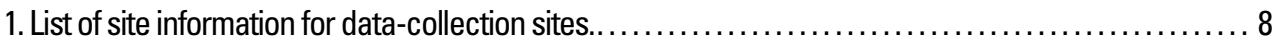

2. Method detection limits for analytes listed in this report ............................... 10

3. Number of samples and median and range of concentrations of nutrient species in Lower and Upper Echo, Fallen Leaf, Spooner, and Marlette Lakes and Echo,

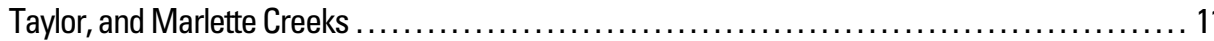

4. Median nutrient concentrations for samples collected from Lower and Upper Echo,

Fallen Leaf, Spooner, and Marlette Lakes from previous studies and this study....

\section{Conversion Factors, Datum, Water-Quality Units, and Acronyms}

\begin{tabular}{lcl}
\hline Multiply & By & To obtain \\
\hline & Length & \\
\hline meter (m) & 1.094 & yard (yd) \\
& Area & \\
\hline & & \\
\hline hectare (ha) & 0.003861 & square mile (mi²) \\
& & \\
\hline & Volume & \\
& & \\
liter (L) & 33.82 & ounce, fluid (fl. oz) \\
liter (L) & 2.113 & quart (qt) \\
liter (L) & 1.057 & gallon (gal) \\
liter (L) & 0.2642 & \\
& &
\end{tabular}

Temperature: Degrees Celsius $\left({ }^{\circ} \mathrm{C}\right)$ can be converted to degrees Fahrenheit $\left({ }^{\circ} \mathrm{F}\right)$ by using the formula ${ }^{\circ} \mathrm{F}=\left[1.8\left({ }^{\circ} \mathrm{C}\right)\right]+32$. Degrees Fahrenheit can be converted to degrees Celsius by using the formula ${ }^{\circ} \mathrm{C}=0.556\left({ }^{\circ} \mathrm{F}-32\right)$.

Sea level: In this report, "sea level" refers to the National Geodetic Vertical Datum of 1929 (NGVD of 1929, formerly called "Sea-Level Datum of 1929"), which is derived from a general adjustment of the first-order leveling networks of the United States and Canada.

Horizontal coordinate information is referenced to the North American Datum of 1983 (NAD 83).

Altitude, as used in this report, refers to distance above the vertical datum.

Specific conductance is given in microsiemens per centimeter at 25 degrees Celsius $\left(\mu \mathrm{S} / \mathrm{cm}\right.$ at $\left.25^{\circ} \mathrm{C}\right)$. 
Water-quality units and related units used in this report:

$\begin{array}{ll}\mathrm{mg} / \mathrm{L} & \text { milligram per liter } \\ \mu \mathrm{g} / \mathrm{L} & \text { microgram per liter } \\ \mu \mathrm{m} & \text { micrometer } \\ \mu \mathrm{S} / \mathrm{cm} & \text { microsiemens per centimeter }\end{array}$

\section{Abbreviations and acronyms:}

$\begin{array}{ll}\text { DOP or SRP } & \text { Dissolved orthophosphorus } \\ \text { EWI } & \text { Equal-width increment } \\ \text { MDLs } & \text { Method detection limits } \\ \mathrm{NH}_{4} & \text { Dissolved ammonia } \\ \mathrm{NO}_{3} & \text { Dissolved nitrate (dissolved nitrate plus nitrite) } \\ \mathrm{NWIS} & \text { National Water Information System } \\ \text { TFe or BaFe } & \text { Total bioreactive iron } \\ \text { TKN } & \text { Total ammonia plus organic nitrogen } \\ \text { TP } & \text { Total phosphorus } \\ \text { TRPA } & \text { Tahoe Regional Planning Agency } \\ \text { USGS } & \text { U.S. Geological Survey }\end{array}$




\title{
Nutrient Concentrations in Upper and Lower Echo, Fallen Leaf, Spooner, and Marlette Lakes and Associated Outlet Streams, California and Nevada, 2002-03
}

\author{
by Michael S. Lico
}

\section{ABSTRACT}

Five lakes and their outlet streams in the Lake Tahoe Basin were sampled for nutrients during 2002-03. The lakes and streams sampled included Upper Echo, Lower Echo, Fallen Leaf, Spooner, and Marlette Lakes and Echo, Taylor, and Marlette Creeks. Water samples were collected to determine seasonal and spatial concentrations of dissolved nitrite plus nitrate, dissolved ammonia, total Kjeldahl nitrogen, dissolved orthophosphate, total phosphorus, and total bioreactive iron. These data will be used by Tahoe Regional Planning Agency in revising threshold values for waters within the Lake Tahoe Basin. Standard U.S. Geological Survey methods of sample collection and analysis were used and are detailed herein. Data collected during this study and summary statistics are presented in graphical and tabular form.

\section{INTRODUCTION}

Nutrients have been identified as a key factor in the decline in clarity of Lake Tahoe within the past few decades (Goldman and others, 1998). The control of nutrient input into Lake Tahoe is one of the major issues being addressed by many agencies in the Lake Tahoe Basin. Millions of dollars are being spent on reducing sediment and nutrient input into Lake Tahoe as a result of a Presidential initiative in 1998. In addition to Lake Tahoe, the Lake Tahoe Basin contains more than 170 other lakes and ponds that may suffer the same problems as Lake Tahoe if nutrient input is not kept in check. The total surface area of the other lakes comprises about 3 percent of Lake Tahoe's area (fig. 1; Hill, 1996).

The Tahoe Regional Planning Agency (TRPA) is tasked with the preservation, restoration, and enhancement of the unique environment of the Lake Tahoe region. Among the several areas that receive attention from TRPA is the quality of surface water in the Lake Tahoe Basin. TRPA is responsible for setting threshold values, or water-quality standards, for waters within the Lake Tahoe Basin. Threshold values for several nutrient species are currently set, but TRPA tentatively will update these values during 2005. Many of the other lakes within the Lake Tahoe Basin have very limited information regarding their water quality, including nutrient concentrations. Most of the water from these lakes eventually is discharged into Lake Tahoe via tributary streams. Many of the tributary streams have a large amount of nutrient and sediment data that have been collected during the past few decades (Rowe and others, 2002).

These lakes within the Lake Tahoe Basin have a wide variety of characteristics. They vary greatly in size, the largest being Fallen Leaf Lake (567 ha). Many of the lakes are small, shallow alpine lakes west of Lake Tahoe. Some of the lakes have enhanced storage that is used as drinking and irrigation sources, such as Lower Echo and Marlette Lakes (figs. $2 A$ and $D$, respectively). The drainage basins or areas for the lakes have differing physiographic, climatic, and geologic characteristics (Smith and others, 1999). Some of the lakes, such as Upper and Lower Echo Lakes (figs. $2 A$ and 3 ) and Fallen Leaf (fig. $2 B$ ), have numerous summer homes near their shores that could input nutrients to the lakes. Spooner (fig. 2C) and Marlette (fig. 2D) Lakes have no developed areas in their drainage basins. Septic systems were replaced at Fallen Leaf Lake in the 1970's with a sewer system that collects septage and exports it out of the Lake Tahoe Basin. At Upper and Lower Echo Lakes, residents are required to dispose of human waste at a central-collection facility near the dam at Lower Echo Lake. Upper and Lower Echo and Fallen Leaf Lakes have motorized-watercraft activity during the summer months, whereas Spooner and Marlette Lakes have none.

The trophic status of the five study area lakes has been described by previous investigators. Upper Echo Lake is oligomesotrophic (Reuter and others, 1996) and has a dominance of blue-green algae and a lack of diatoms. Lower Echo Lake is classified as oligotrophic and has minimal amounts of diatoms and much less contribution by blue-green algae (Reuter and others, 1996). Fallen Leaf Lake is described as near ultraoligotrophic by Reuter and others (1996) and has a dominance of diatoms and no blue-green algae. Spooner Lake is classified as meso-oligotrophic by Sater (1994), but she indicates that the lake could be mesoeutrophic at times, especially if the attached macrophyte community is considered. Green algae dominate the phytoplankton community in Spooner Lake with blue-green algae and diatoms present in varying numbers. The trophic level of Marlette Lake is classified as mesotrophic according to Sater (1994). The phytoplankton community is dominated by bluegreen algae and diatoms. 


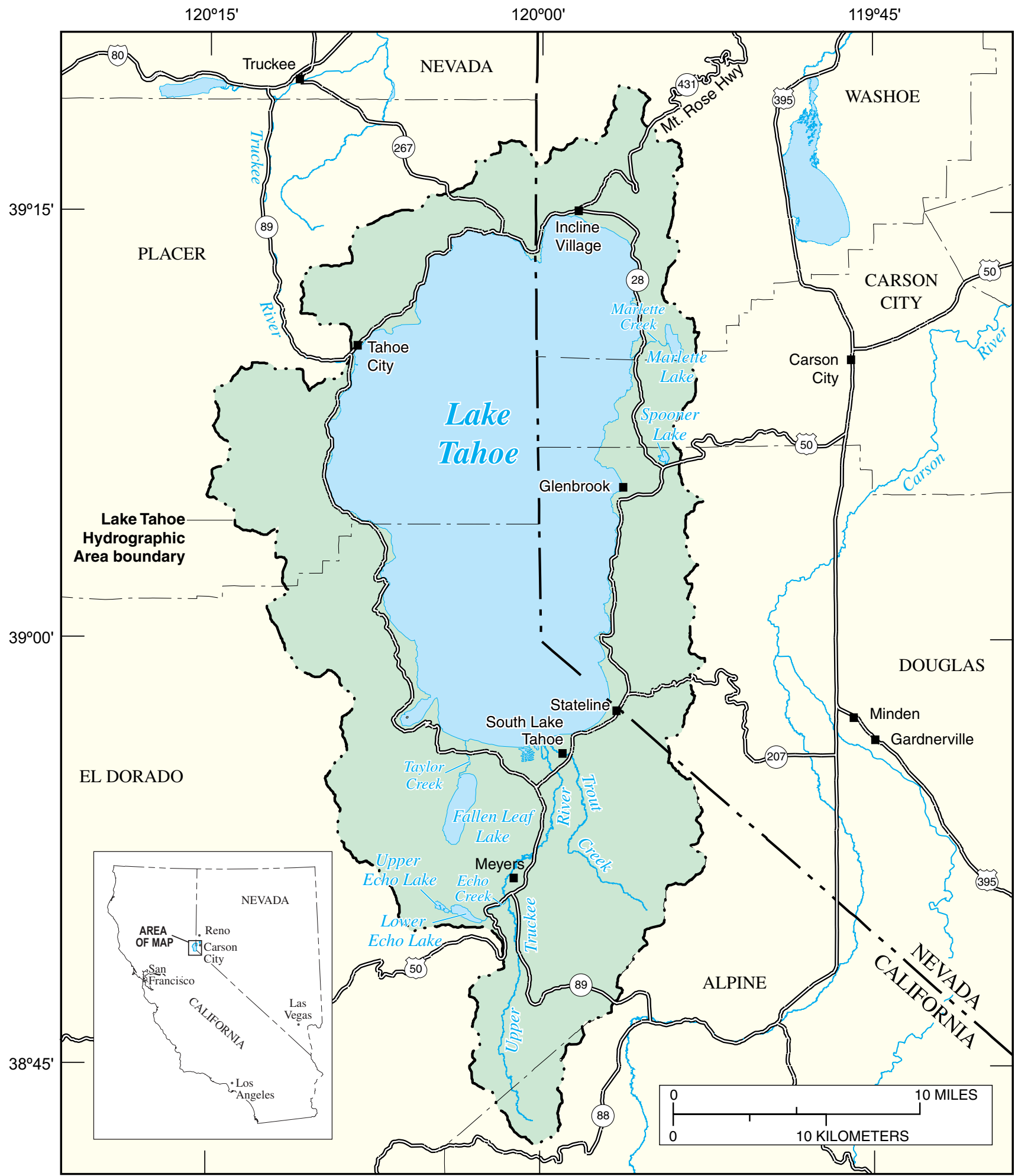

Base from U.S. Geological Survey digital data, 1:24,000 and 1:100,000, 1969-85. Universal Transverse Mercator projection, Zone 11

Figure 1. Location of study area, Nevada and California. 
$A$

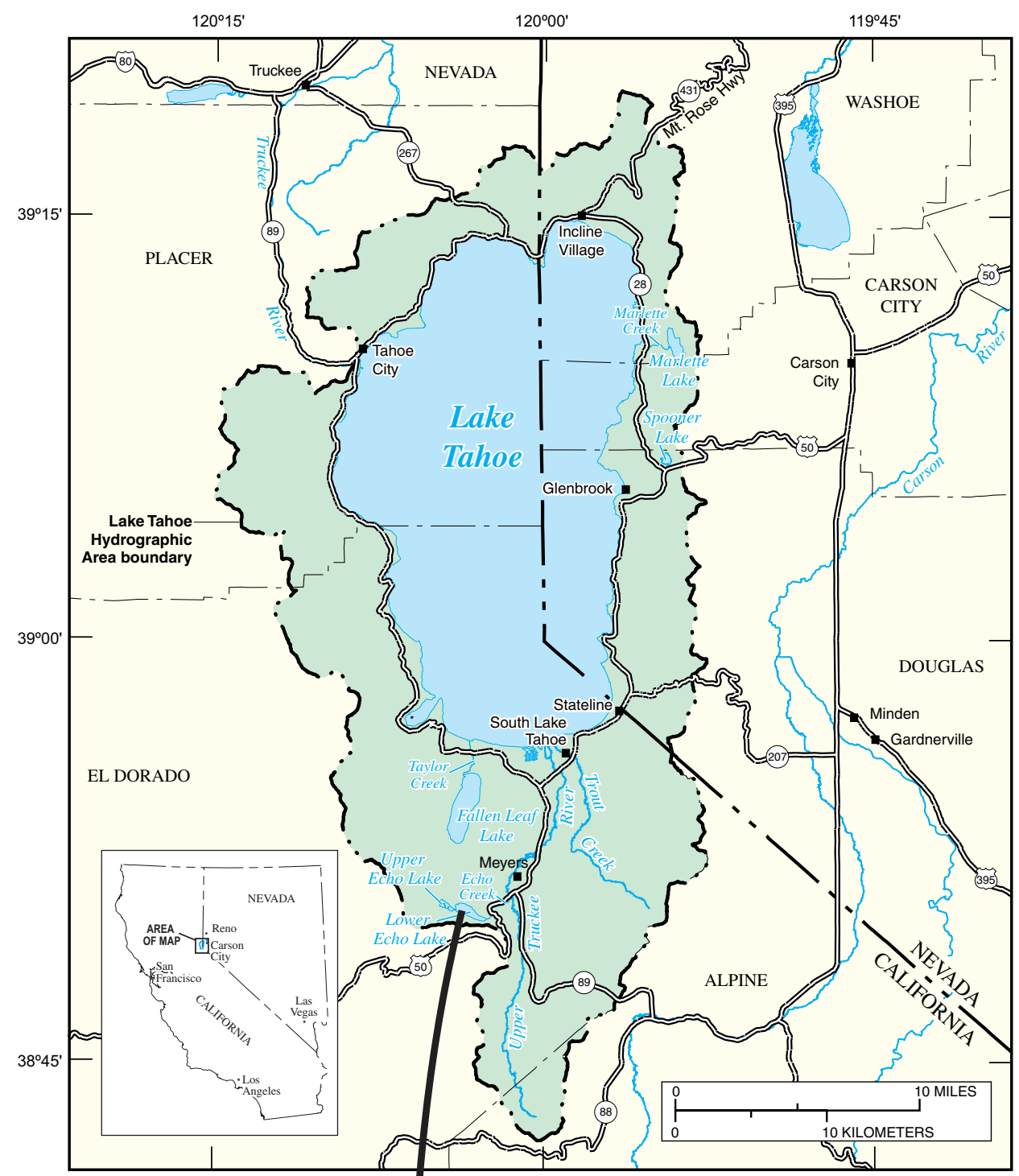

Base from U.S. Geological Survey digital data, 1:24,000 and 1:100,000, 1969-85.

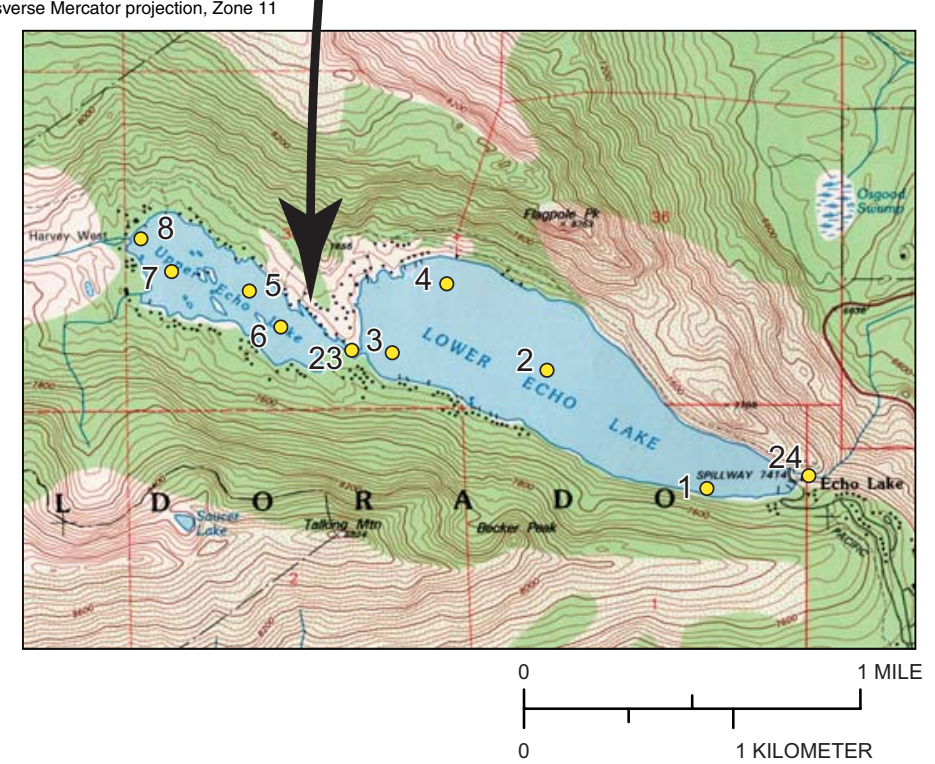

Figure 2. Location of sampling sites in: $(A)$ Upper and Lower Echo Lakes, $(B)$ Fallen Leaf Lake, $(C)$ Spooner Lake, and $(D)$ Marlette Lake. 
$B$

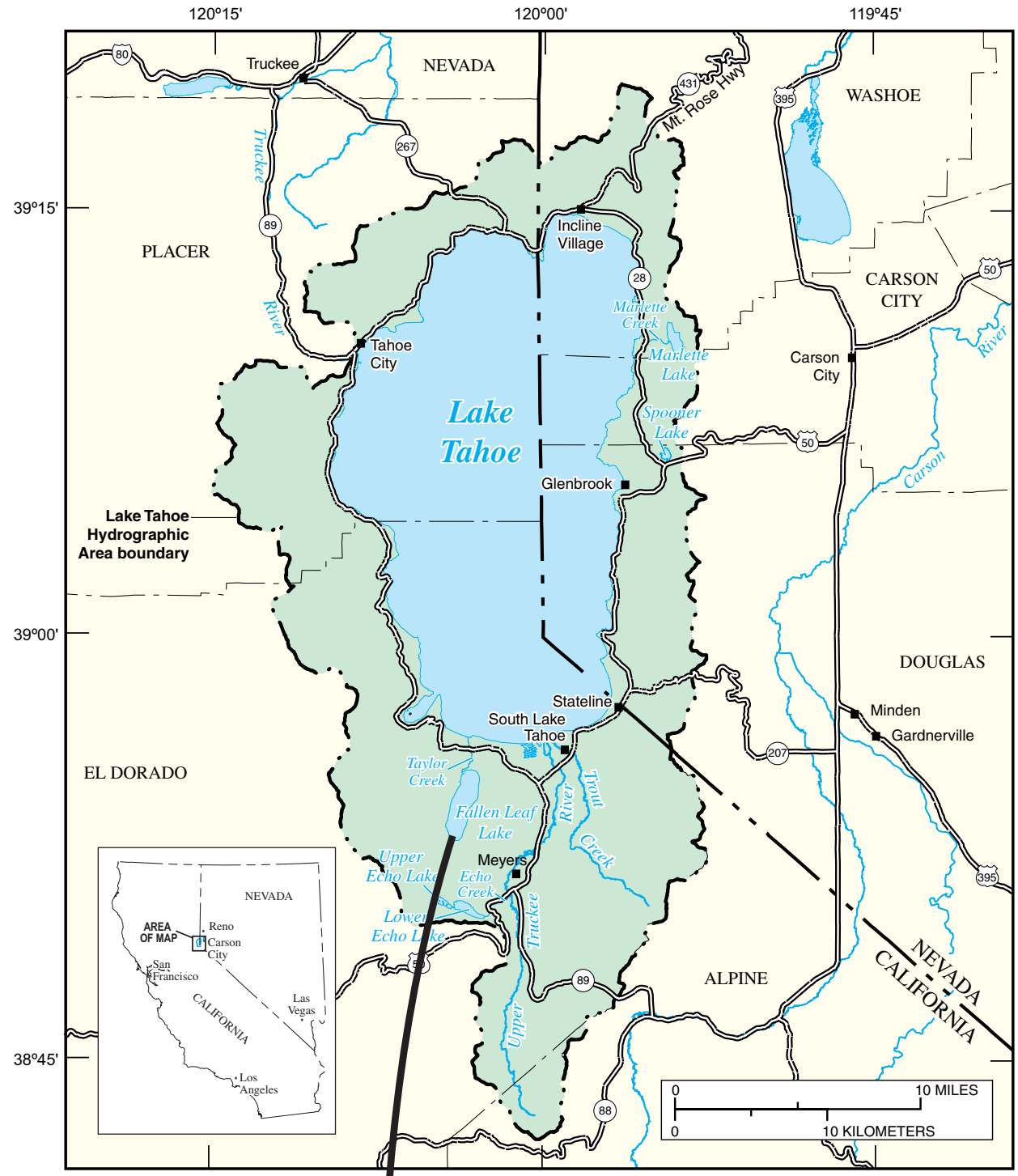

Base from U.S. Geological Survey digital data, 1:24 000 and 1:100,000, 1969-85. Universal Transverse Mercator projection, Zone 11

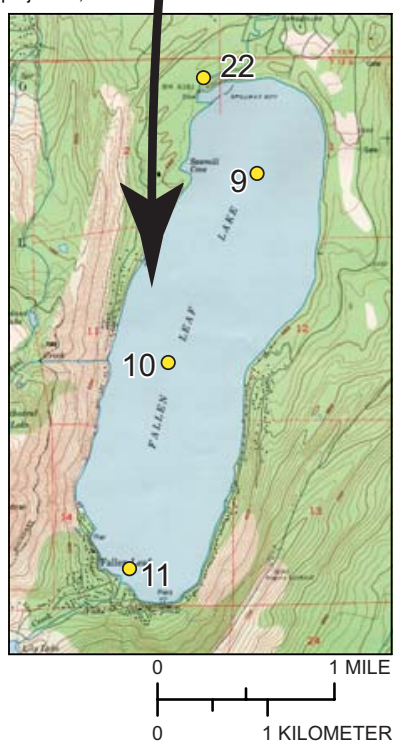

Figure 2. Location of sampling sites in: $(A)$ Upper and Lower Echo Lakes, $(B)$ Fallen Leaf Lake, (C) Spooner Lake, and (D) Marlette Lake-Continued. 


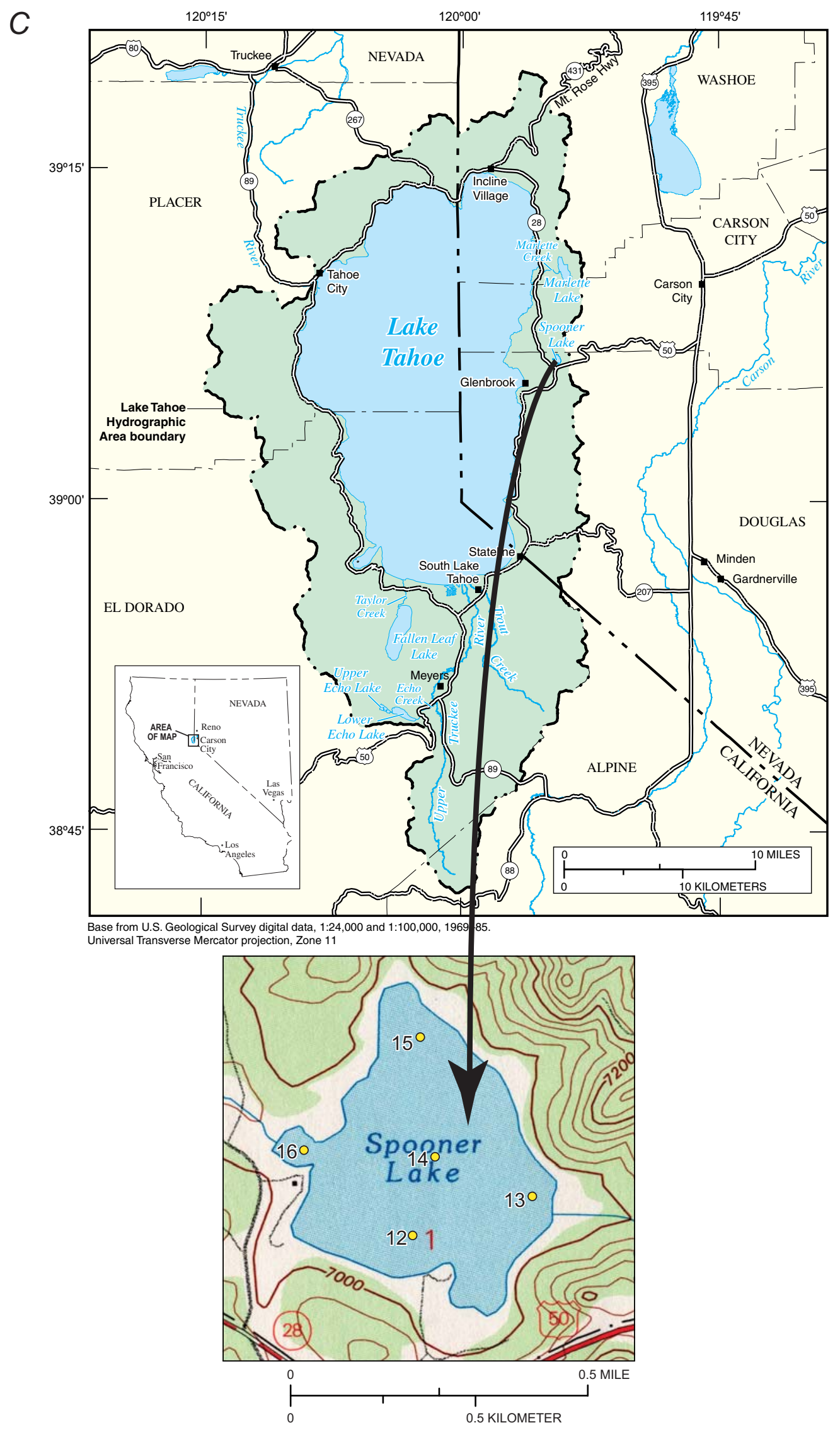

Figure 2. Location of sampling sites in: $(A)$ Upper and Lower Echo Lakes, $(B)$ Fallen Leaf Lake, (C) Spooner Lake, and (D) Marlette Lake-Continued. 
D

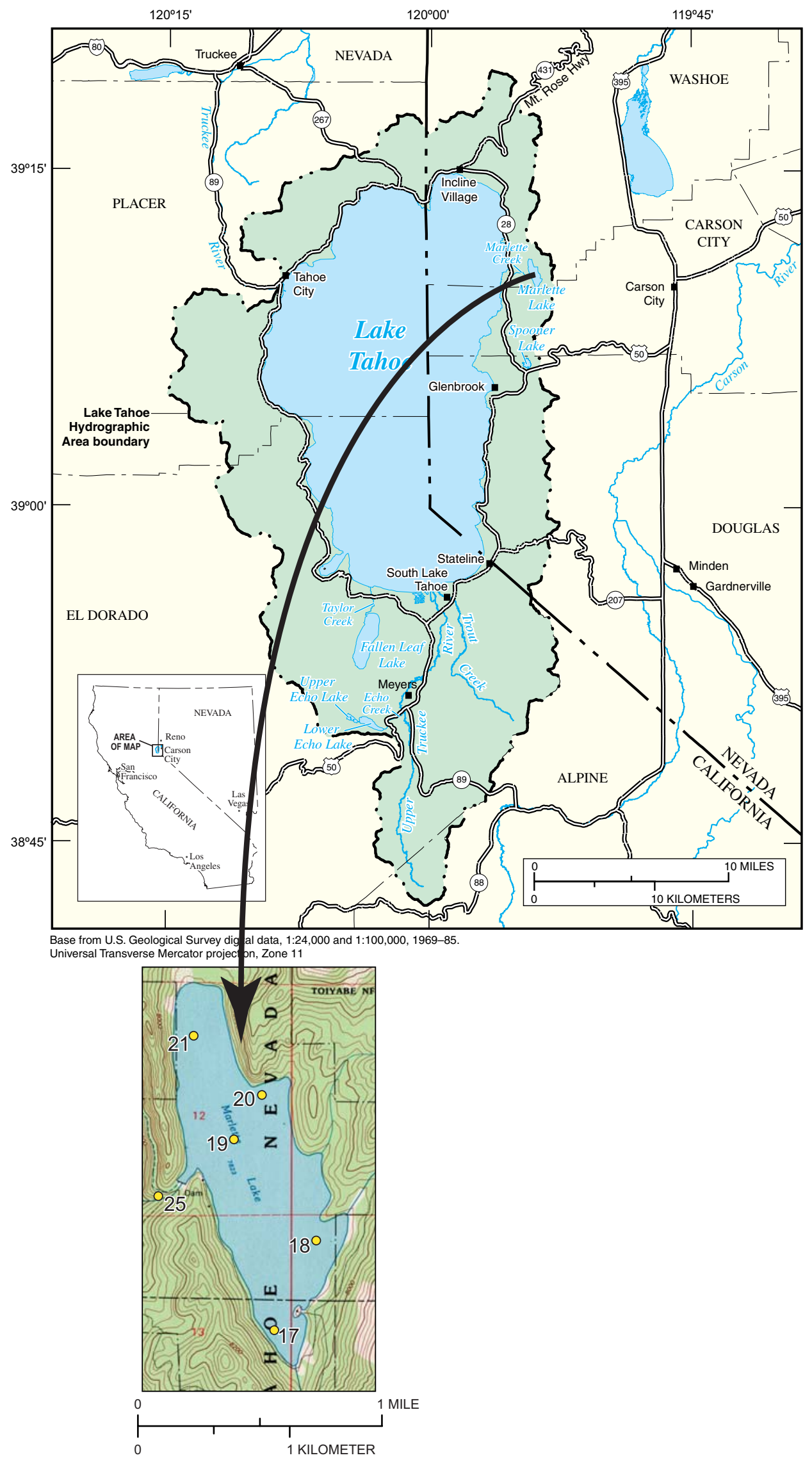

Figure 2. Location of sampling sites in: $(A)$ Upper and Lower Echo Lakes, $(B)$ Fallen Leaf Lake, $(C)$ Spooner Lake, and (D) Marlette Lake-Continued. 


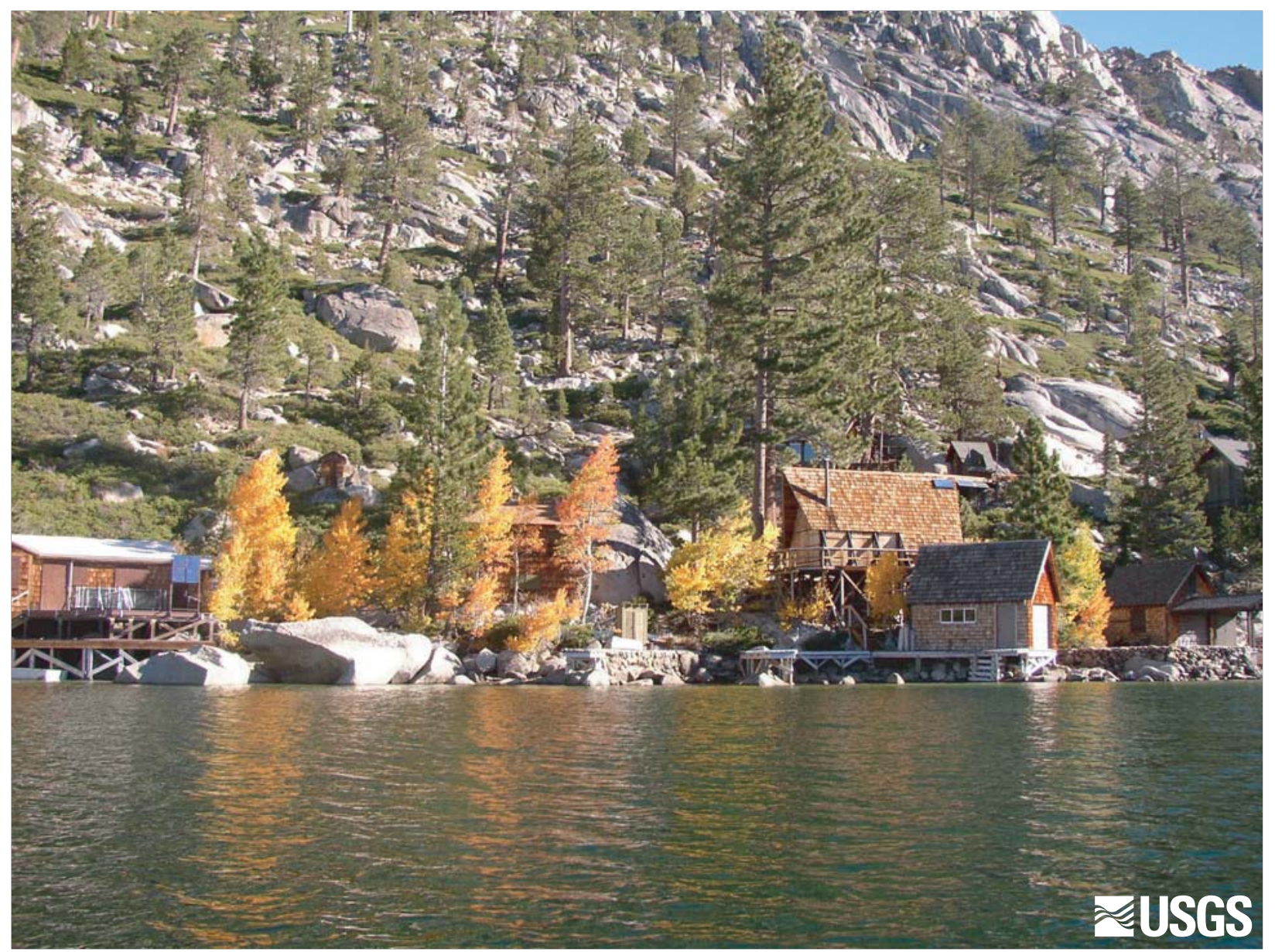

Figure 3. Summer homes along shore of Lower Echo Lake.

\section{Purpose and Scope}

The purpose of this report is to describe water-quality and field data collected during this study. This report includes nutrient concentrations and field data collected during 2002-03 from Upper and Lower Echo, Fallen Leaf, Spooner, and Marlette Lakes within the Lake Tahoe Basin and Echo, Taylor, and Marlette Creeks (fig. 1; table 1) that drain three of these lakes. The following nutrient data were collected: dissolved nitrate plus nitrite $\left(\mathrm{NO}_{3}\right)$, dissolved ammonia $\left(\mathrm{NH}_{4}\right)$, total ammonia plus organic nitrogen (TKN), dissolved orthophosphorus (DOP or $\mathrm{SRP}$ ), total phosphorus (TP), and total bioreactive iron (TFe or $\mathrm{BaFe})$. The following field parameters were measured in depth profiles for the lakes and at the centroid of flow in the streams: water temperature, specific conductance, dissolved oxygen, $\mathrm{pH}$, and turbidity. In the lakes, water transparency was measured with a Secchi disc.

\section{Previous Studies of Nutrient Concentrations in Lake Tahoe Basin Lakes}

Few sources of nutrient data exist for the waters of Upper and Lower Echo, Fallen Leaf, Spooner, and Marlette Lakes. Available sources include a study on Lake Tahoe Basin water quality by the State of California (1962), a study of Fallen Leaf Lake by the U.S. Geological Survey (USGS; Fuller, 1975), a nationwide study by the U.S. Environmental Protection Agency (Landers and others, 1987) that reported data for many wilderness lakes in California, a report published by University of California, Davis (UCD), one on nutrients in Spooner and Marlette Lakes (Sater, 1994) and the other on water chemistry of Upper and Lower Echo and Fallen Leaf Lakes (Reuter and others, 1996), and data collected by the USGS and published in TRPA annual water-quality reports (Hill, 1992, 1996) and a USGS Annual Data Report (Preissler and others, 1999). 
8 Nutrients in Upper and Lower Echo, Fallen Leaf, Spooner, and Marlette Lakes and Associated Streams, CA and NV, 2002-03

Table 1. Site information for data-collection sites

[Horizontal coordinate information is referenced to the North American Datum of 1983 (NAD83)]

\begin{tabular}{|c|c|c|c|c|}
\hline \multirow{2}{*}{$\begin{array}{c}\text { Site no. } \\
\text { (see } \\
\text { fig. 2) }\end{array}$} & \multirow{2}{*}{ Site name } & \multirow{2}{*}{ Site identification no. } & Latitude & Longitude \\
\hline & & & \multicolumn{2}{|c|}{ in degrees, minutes, and seconds } \\
\hline \multicolumn{5}{|c|}{ Lake sites } \\
\hline 1 & Lower Echo Lake, east & 385005120025801 & $38^{\circ} 50^{\prime} 05^{\prime \prime}$ & $120^{\circ} 02^{\prime} 58^{\prime \prime}$ \\
\hline 2 & Lower Echo Lake near center & 385023120032501 & $38^{\circ} 50^{\prime} 23^{\prime \prime}$ & $120^{\circ} 03^{\prime} 25^{\prime \prime}$ \\
\hline 3 & Lower Echo Lake, southwest & 385025120035901 & $38^{\circ} 50^{\prime} 25^{\prime \prime}$ & $120^{\circ} 03^{\prime} 59^{\prime \prime}$ \\
\hline 4 & Lower Echo Lake, northwest & 385036120034801 & $38^{\circ} 50^{\prime} 36^{\prime \prime}$ & $120^{\circ} 03^{\prime} 48^{\prime \prime}$ \\
\hline 5 & Upper Echo Lake near center & 385035120042301 & $38^{\circ} 50^{\prime} 35^{\prime \prime}$ & $120^{\circ} 04^{\prime} 23^{\prime \prime}$ \\
\hline 6 & Upper Echo Lake, east & 385029120042001 & $38^{\circ} 50^{\prime} 29^{\prime \prime}$ & $120^{\circ} 04^{\prime} 20^{\prime \prime}$ \\
\hline 7 & Upper Echo Lake, southwest & 385038120044201 & $38^{\circ} 50^{\prime} 38^{\prime \prime}$ & $120^{\circ} 04^{\prime} 42^{\prime \prime}$ \\
\hline 8 & Upper Echo Lake near inlet & 385043120044801 & $38^{\circ} 50^{\prime} 43^{\prime \prime}$ & $120^{\circ} 04^{\prime} 48^{\prime \prime}$ \\
\hline 9 & Fallen Leaf Lake, north & 385256120040501 & $38^{\circ} 52^{\prime} 56^{\prime \prime}$ & $120^{\circ} 04^{\prime} 05^{\prime \prime}$ \\
\hline 10 & Fallen Leaf Lake near center & 385356120035001 & $38^{\circ} 53^{\prime} 56^{\prime \prime}$ & $120^{\circ} 03^{\prime} 50^{\prime \prime}$ \\
\hline 11 & Fallen Leaf Lake, south & 385450120032101 & $38^{\circ} 54^{\prime} 50^{\prime \prime}$ & $120^{\circ} 03^{\prime} 21^{\prime \prime}$ \\
\hline 12 & Spooner Lake, south & 390621119543201 & $39^{\circ} 06^{\prime} 21^{\prime \prime}$ & $119^{\circ} 54^{\prime} 32^{\prime \prime}$ \\
\hline 13 & Spooner Lake, east & 390622119542601 & $39^{\circ} 06^{\prime} 22^{\prime \prime}$ & $119^{\circ} 54^{\prime} 26^{\prime \prime}$ \\
\hline 14 & Spooner Lake near center & 390625119542801 & $39^{\circ} 06^{\prime} 25^{\prime \prime}$ & $119^{\circ} 54^{\prime} 28^{\prime \prime}$ \\
\hline 15 & Spooner Lake, north & 390628119542501 & $39^{\circ} 06^{\prime} 28^{\prime \prime}$ & $119^{\circ} 54^{\prime} 25^{\prime \prime}$ \\
\hline 16 & Spooner Lake, west & 390628119544301 & $39^{\circ} 06^{\prime} 28^{\prime \prime}$ & $119^{\circ} 54^{\prime} 43^{\prime \prime}$ \\
\hline 17 & Marlette Lake, south & 390949119535501 & $39^{\circ} 09^{\prime} 49^{\prime \prime}$ & $119^{\circ} 53^{\prime} 55^{\prime \prime}$ \\
\hline 18 & Marlette Lake, southeast & 391010119534301 & $39^{\circ} 10^{\prime} 10^{\prime \prime}$ & $119^{\circ} 53^{\prime} 43^{\prime \prime}$ \\
\hline 19 & Marlette Lake near center & 391033119540301 & $39^{\circ} 10^{\prime} 33^{\prime \prime}$ & $119^{\circ} 54^{\prime} 03^{\prime \prime}$ \\
\hline 20 & Marlette Lake, east & 391043119535501 & $39^{\circ} 10^{\prime} 43^{\prime \prime}$ & $119^{\circ} 53^{\prime} 55^{\prime \prime}$ \\
\hline 21 & Marlette Lake, north & 391056119541801 & $39^{\circ} 10^{\prime} 56^{\prime \prime}$ & $119^{\circ} 54^{\prime} 18^{\prime \prime}$ \\
\hline \multicolumn{5}{|c|}{ Stream sites } \\
\hline 22 & Taylor Creek near Camp Richardson, CA & 10336626 & $38^{\circ} 55^{\prime} 18^{\prime \prime}$ & $120^{\circ} 03^{\prime} 37^{\prime \prime}$ \\
\hline 23 & Echo Lakes Channel & 385026120040301 & $38^{\circ} 50^{\prime} 38^{\prime \prime}$ & $120^{\circ} 04^{\prime} 10^{\prime \prime}$ \\
\hline 24 & Echo Creek at outlet near Phillips, CA & 103366082 & $38^{\circ} 50^{\prime} 07^{\prime \prime}$ & $120^{\circ} 02^{\prime} 34^{\prime \prime}$ \\
\hline 25 & Marlette Creek near Carson City, NV & 10336715 & $39^{\circ} 10^{\prime} 20^{\prime \prime}$ & $119^{\circ} 54^{\prime} 25^{\prime \prime}$ \\
\hline
\end{tabular}

\section{Acknowledgments}

The author thanks the Tahoe Regional Planning Agency for providing funding for this study. Field personnel who assisted in this project were: Rita Whitney (TRPA) and Jim Wood, Carl Thodal, Sienna Sager-Smith, and Dave Berger (USGS).

\section{WATER SAMPLING METHODS}

Water samples were collected during three time periods for two consecutive years near the center of each lake (fig. 2). Specifically, water samples were obtained just after ice-out in May or June (Fallen Leaf Lake does not freeze over), during mid-summer when lakes were stratified, and during the fall when the lakes had turned over. Normally, an intermediate layer of maximum temperature gradient, called the thermocline, forms between an upper layer and a lower layer called the epilimnion and hypolimnion, respectively. Samples were obtained from the epilimnion at a depth of 1 or $2 \mathrm{~m}$, and when the lakes were stratified an additional sample was taken from the hypolimnion, which varied at each lake and with the season. During the summer of 2002, several sites in each lake were sampled to determine the spatial variability within the lakes.

At each lake site, field values in a vertical profile of water temperature, specific conductance, dissolved oxygen, and $\mathrm{pH}$ were measured with a calibrated Hydrolab multiparameter sonde. Standard USGS protocols (U.S. Geological Survey, 1997) were used in the calibration and measurements of field values in the lake profiles. Water transparency was measured in the lakes with a Secchi disc. Water samples were collected from the lakes using a 1-L all Teflon Kemmerer sampler suspended from a nylon line that was lowered from a boat. The water samples were brought on-board and composited into an $8-\mathrm{L}$ churn splitter (fig. 4). Subsamples were taken from the churn for the determination of turbidity and for the whole-water analyses of nutrients (TKN, TP, and TFe). A subsample from the churn was then filtered through a $0.45-\mu \mathrm{m}$ mixed cellulose ester membrane for the determination of filtered nutrients $\left(\mathrm{NH}_{4}\right.$, $\mathrm{NO}_{3}$, and DOP). 


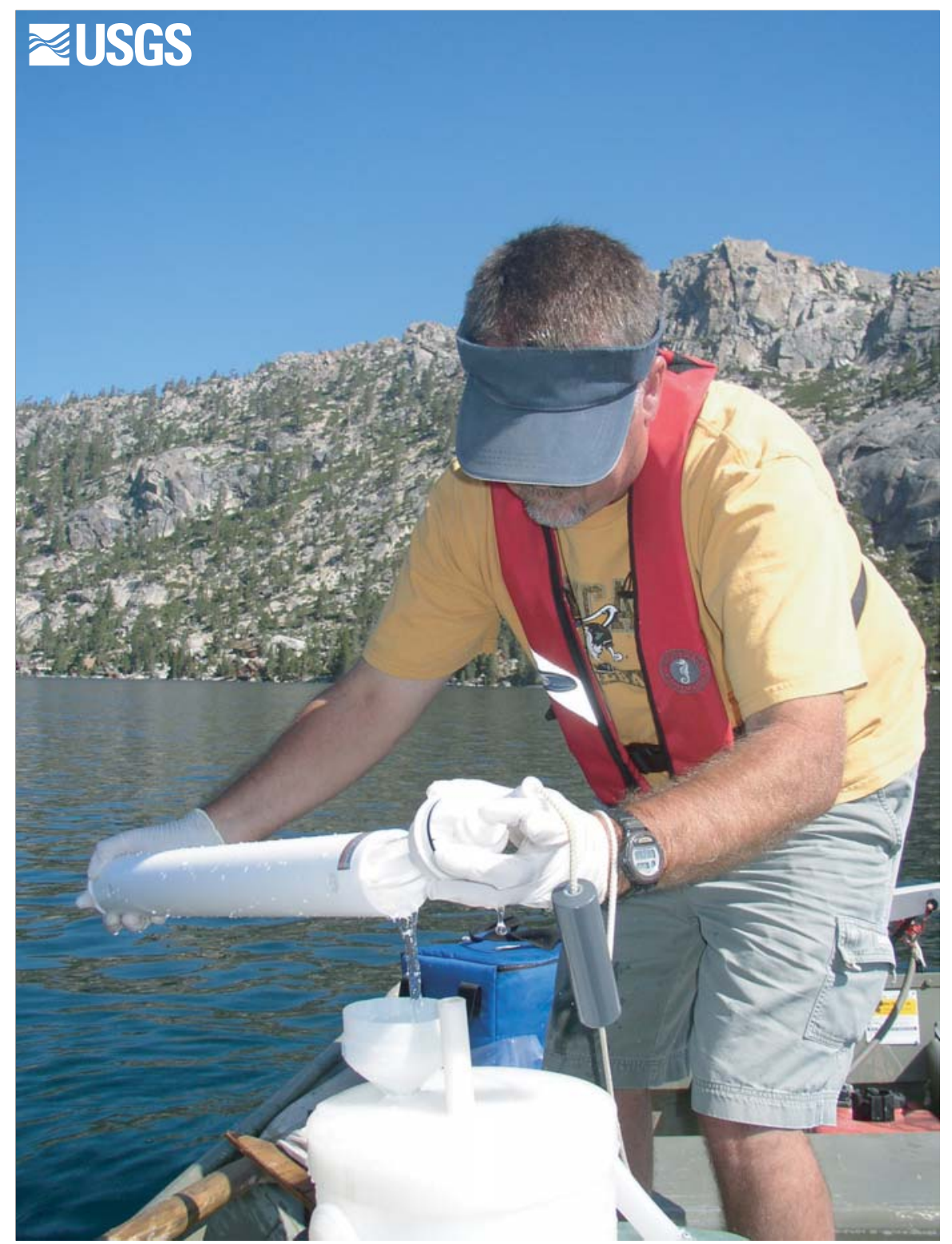

Figure 4. Sample collection at Lower Echo Lake. An all-Teflon sampler was used to obtain samples from various depths in the lakes.

At each stream site, field values of water temperature, specific conductance, dissolved oxygen, and $\mathrm{pH}$ were measured with a calibrated Hydrolab multiparameter sonde. Standard USGS protocols (U.S. Geological Survey, 1997) were used in the calibration and measurements of field values in the streams. Stream-water samples were collected using the equal-width increment (EWI) depth-integrated method described by U.S. Geological Survey (1997) where sample points were determined by dividing the stream into equal segments across the channel. Depth-integrated samples were then taken at the center of these segments with a hand sampler fitted with a Teflon nozzle and bottle and composited into an 8-L polyethylene churn splitter. When streamflow was inadequate to use the EWI method, samples were obtained at the centroid of flow by dipping a 1-L wide-mouthed Teflon bottle into the stream. Subsamples were drawn from the churn splitter in the same manner as those for the lake samples. Turbidity was measured on a subsample drawn from the churn splitter. Field methods for the collection of water samples closely followed those outlined by the USGS (1997). 


\section{LABORATORY ANALYSES}

Water samples were analyzed at the University of California at Davis, Tahoe Research Group Limnology Laboratory in Davis, California. $\mathrm{NH}_{4}$ was determined by the indenophenol colorimetric method described by Brzezinski (1987). $\mathrm{NO}_{3}$ was determined by the Hydrazine method reported by Kempers and Luft (1988) where $\mathrm{NO}_{3}$ is reduced to nitrite by a hydrazinecopper solution and the subsequent color measured by a spectrophotometer. However, the analysis of $\mathrm{NO}_{3}$ was changed to a new method in May 2003. The new method consists of a colorimetric determination of $\mathrm{NO}_{3}$ concentrations by the Hydrazine method with the addition of sodium pyrophosphate to reduce interferences by calcium and magnesium (Kamphake and others, 1967; Strickland and Parsons, 1972). Both analytical methods for $\mathrm{NO}_{3}$ were used after May 2003, but only the results of the older method are used in the statistical summaries reported in this document. TKN was quantified using a method described by Fishman and Friedman (1985). The colorimetric phosphomolybdate method of Murphy and Riley (1962) and Eaton and others (1995) was used to determine DOP by complexation with an antimony-molybdenum solution. TP was determined by the same method as DOP with the addition of a digestion of the sample with persulfate prior to complexation (Fishman and Friedman, 1985). TFe was determined using a method described by Stookey (1970), which employs the use of colored complex that is measured by a spectrophotometer. Method detection limits (MDLs) for the above described methods are listed in table 2 .

Table 2. Method detection limits for analytes listed in this report

[Analyses were performed at the University of California, Davis Limnology Laboratory in Davis, CA. Abbreviation: MDL, method detection limit]

\begin{tabular}{ll}
\hline \multicolumn{1}{c}{ Analyte } & $\begin{array}{l}\mathrm{MDL}^{\mathrm{a}} \\
(\mu \mathrm{g} / \mathrm{L})\end{array}$ \\
\hline Ammonia nitrogen & $3.0 \mathrm{as} \mathrm{N}$ \\
Nitrate plus nitrite nitrogen & $2.0 \mathrm{as} \mathrm{N}$ \\
Organic plus ammonia nitrogen (Kjeldahl nitrogen) & 35 as N \\
Orthophosphate (soluble reactive phosphorus) & 1.0 as P \\
Total phosphorus & 2.0 as P \\
Bioreactive iron & 3.0 as Fe \\
\hline
\end{tabular}

${ }^{\mathrm{a}}$ Method detection limit: Minimum concentration of a substance that can be measured and reported with 99-percent confidence that the analyte concentration is greater than zero (Childress and others, 1999).

\section{RESULTS}

Data collected during this study represent those conditions that existed at the time of sample collection and do not necessarily represent conditions at other times. Profile data collected at each lake site during sample collection are shown at back of report in figure 5 and listed in appendix A. Field data (transparency, turbidity, barometric pressure, and air temperature) are included in appendix B along with the analytical results for nutrients. Appendix $\mathrm{C}$ lists all data collected in the field and the nutrient concentrations for samples from the streams. Appendix D reports values for $\mathrm{NO}_{3}$ determined on samples collected after May 2003 using the newly adopted Hydrazine method with sodium pyrophosphate addition (see Laboratory Analyses section).

Listed in table 3 are the median concentration values for all nutrient analytes, the number of samples, the range of concentrations, and the median values and ranges of concentrations for the epilimnion and hypolimnion of each lake. Also listed in table 3 are median values, number of samples, and ranges for nutrient concentrations in water samples collected from the streams. For comparative purposes, a summary of available data from previous investigations at these lakes is listed in table 4.

Boxplots are a useful way of showing the basic distribution characteristics of data. They display percentiles (typically the $10^{\text {th }}, 25^{\text {th }}, 50^{\text {th }}$ (median), $75^{\text {th }}$, and $90^{\text {th }}$ ) and allow a graphical method to easily compare two or more sets of data. Boxplots for nutrient concentration data collected during this study are shown in figure 6, at back of report, for lake samples. Samples collected from the streams were not of sufficient numbers to show the basic distribution characteristics of data; thus, the plots for stream nutrient data show the actual values for the three streams (fig. 7 at back of report).

$\mathrm{NO}_{3}$ concentrations generally were low in lake samples and median values were less than $6 \mu \mathrm{g} / \mathrm{L}$ as $\mathrm{N}$ in all lakes. Upper Echo Lake had the highest median $\mathrm{NO}_{3}$ concentration of all five lakes, but Fallen Leaf Lake had the highest concentration $(47.4 \mu \mathrm{g} / \mathrm{L}$ as N) observed during this study (table 3$)$. Concentrations of $\mathrm{NO}_{3}$ generally were slightly lower in the epilimnion than the hypolimnion, except in Lower Echo Lake. The streams generally had higher concentrations of $\mathrm{NO}_{3}$ than did the lakes (figs. $6 A$ and $7 A$ ) with median concentrations ranging from 8.9 to $37.7 \mu \mathrm{g} / \mathrm{L}$ as $\mathrm{N}$. The maximum $\mathrm{NO}_{3}$ concentration was found in a sample from Marlette Creek $(71.8 \mu \mathrm{g} / \mathrm{L}$ as $\mathrm{N})$.

Median dissolved $\mathrm{NH}_{4}$ concentrations in lake samples range from 5.6 to $8.1 \mu \mathrm{g} / \mathrm{L}$ as $\mathrm{N}$ (table 3). Marlette Lake had the highest median $\mathrm{NH}_{4}$ concentration $(8.1 \mu \mathrm{g} / \mathrm{L}$ as $\mathrm{N})$ and the highest single observed concentration $(28.8 \mu \mathrm{g} / \mathrm{L}$ as $\mathrm{N})$. The epilimnion of Upper and Lower Echo Lakes had a higher median $\mathrm{NH}_{4}$ concentration than their respective concentrations in the hypolimnion (table 3). Fallen Leaf, Spooner, and Marlette Lakes had higher median $\mathrm{NH}_{4}$ concentrations in samples from the hypolimnion than those from the epilimnion. Median $\mathrm{NH}_{4}$ concentrations in streams ranged from 5.2 to $7.8 \mu \mathrm{g} / \mathrm{L}$ as N. 
Table 3. Number of samples and median and range of concentrations of nutrient species in Lower and Upper Echo, Fallen Leaf, Spooner, and Marlette Lakes and Echo, Taylor, and Marlette Creeks

[Symbol: <, less than. For each site and constituent, the top number is the median value and the bottom numbers are the ranges of concentrations at that site; concentrations are expressed as micrograms per liter as $\mathrm{N}$, P, or Fe]

\begin{tabular}{|c|c|c|c|c|c|c|c|c|}
\hline $\begin{array}{l}\text { Site name } \\
\text { (see fig. 2) }\end{array}$ & Data type & $\begin{array}{l}\text { Number of } \\
\text { samples }\end{array}$ & Dissolved nitrate $^{a}$ & $\begin{array}{l}\text { Dissolved } \\
\text { ammonia }\end{array}$ & $\begin{array}{l}\text { Total Kjeldahl } \\
\text { nitrogen }\end{array}$ & $\begin{array}{c}\text { Dissolved } \\
\text { orthophosphate }\end{array}$ & Total phosphorus & $\begin{array}{l}\text { Total bioreactive } \\
\text { iron }\end{array}$ \\
\hline \multirow{6}{*}{$\begin{array}{l}\text { Lower Echo Lake } \\
\text { (sites 1-4) }\end{array}$} & all data & 17 & 4.8 & 5.6 & 108 & $<1.0$ & 4.5 & 19.3 \\
\hline & & & $2.0-16.0$ & $<3.0-18.8$ & $75-202$ & $<1.0-2.6$ & $2.6-5.8$ & $13.4-38.8$ \\
\hline & epilimnion & 9 & 5.6 & 6.6 & 96 & $<1.0$ & 4.2 & 17.0 \\
\hline & & & $3.8-16.0$ & $<3.0-18.8$ & $75-144$ & $<1.0-2.6$ & $2.6-5.8$ & $13.4-33.7$ \\
\hline & hypolimnion & 8 & 4.1 & 3.3 & 122 & $<1.0$ & 4.5 & 29.5 \\
\hline & & & $2.0-10.4$ & $<3.0-8.9$ & 80-202 & $<1.0-2.1$ & $4.1-5.8$ & $18.7-38.8$ \\
\hline \multirow{6}{*}{$\begin{array}{l}\text { Upper Echo Lake } \\
\text { (sites 5-8) }\end{array}$} & all data & 15 & 5.6 & ${ }^{\mathrm{b}} 6.1$ & $\mathrm{~b}_{116}$ & $<1.0$ & 5.4 & 33.4 \\
\hline & & & $3.5-39.9$ & $<3.0-9.3$ & $56-359$ & $<1.0-1.7$ & $4.0-7.5$ & $20.5-200.7$ \\
\hline & epilimnion & 8 & 5.3 & 7.5 & 108 & $<1.0$ & 5.0 & 32.6 \\
\hline & & & $3.5-39.9$ & $<3.0-9.3$ & $56-165$ & $<1.0-1.5$ & $4.6-5.7$ & $20.5-63.2$ \\
\hline & hypolimnion & 7 & 6.0 & ${ }^{c} 5.2$ & ${ }^{c} 130$ & $<1.0$ & 6.0 & 42.2 \\
\hline & & & $3.5-34.5$ & $<3.0-9.3$ & $70-359$ & $<1.0-1.7$ & $4.0-7.5$ & 20.9-200.7 \\
\hline \multirow{6}{*}{$\begin{array}{l}\text { Fallen Leaf Lake } \\
\text { (sites 9-11) }\end{array}$} & all data & 16 & 4.0 & 6.2 & 73 & $<1.0$ & 3.8 & ${ }^{\mathrm{d}} 8.5$ \\
\hline & & & $3.1-47.4$ & $<3.0-13.7$ & $<35-254$ & $<1.0-1.4$ & $2.1-7.6$ & $6.1-34.7$ \\
\hline & epilimnion & 8 & 3.5 & 5.2 & 73 & $<1.0$ & 3.5 & 8.9 \\
\hline & & & $3.1-47.4$ & $<3.0-11.7$ & $38-254$ & $<1.0-1.2$ & $2.1-5.4$ & $6.1-31.6$ \\
\hline & hypolimnion & 8 & 4.4 & 6.2 & 70 & $<1.0$ & 4.0 & ${ }^{\mathrm{e}} 7.5$ \\
\hline & & & $3.6-7.7$ & $3.2-13.7$ & $<35-170$ & $<1.0-1.4$ & $2.8-7.6$ & $6.1-34.7$ \\
\hline \multirow{6}{*}{$\begin{array}{l}\text { Spooner Lake } \\
\text { (sites 12-16) }\end{array}$} & all data & 16 & 5.0 & 5.6 & $\mathrm{~b}_{548}$ & $<1.0$ & 18.5 & $\mathrm{~d}_{150}$ \\
\hline & & & $<2.0-24.1$ & $<3.0-14.7$ & $120-892$ & $<1.0-3.0$ & $13.6-60.4$ & $17.9-7,436$ \\
\hline & epilimnion & 11 & 4.2 & 5.2 & $\mathrm{f}_{465}$ & $<1.0$ & 18.1 & 150 \\
\hline & & & $<2.0-8.4$ & $<3.0-14.7$ & $120-816$ & $<1.0-3.0$ & $13.6-60.4$ & 17.9-995.2 \\
\hline & hypolimnion & 5 & 6.2 & 5.8 & 618 & $<1.0$ & 29.4 & $\mathrm{~g}_{873}$ \\
\hline & & & $<2.0-24.1$ & $<3.0-13.5$ & $452-892$ & $<1.0-1.2$ & $17.2-39.5$ & $48.2-7,436$ \\
\hline \multirow{5}{*}{$\begin{array}{l}\text { Marlette Lake } \\
\text { (sites 17-21) }\end{array}$} & all data & 17 & 5.0 & 8.1 & $\mathrm{~d}_{254}$ & $<1.0$ & 10.8 & 56.4 \\
\hline & & & $3.3-9.5$ & $<3.0-28.8$ & $87-376$ & $<1.0-1.2$ & $5.5-20.5$ & $42.5-366.6$ \\
\hline & epilimnion & 11 & 4.8 & 7.1 & $\mathrm{~h}_{200}$ & $<1.0$ & 6.4 & 49.3 \\
\hline & & & $3.3-7.3$ & $<3.0-16.9$ & $87-376$ & $<1.0-1.0$ & $5.5-14.3$ & $42.5-299.2$ \\
\hline & hypolimnion & 6 & 5.9 & 12.0 & $\mathrm{i}_{280}$ & $<1.0$ & 14.6 & 145 \\
\hline
\end{tabular}


Table 3. Number of samples and median and range of concentrations of nutrient species in Lower and Upper Echo, Fallen Leaf, Spooner, and Marlette Lakes and Echo, Taylor, and Marlette Creeks—Continued

[Symbol: <, less than. For each site and constituent, the top number is the median value and the bottom numbers are the ranges of concentrations at that site; concentrations are expressed as micrograms per liter as $\mathrm{N}, \mathrm{P}$, or $\mathrm{Fe}]$

\begin{tabular}{|c|c|c|c|c|c|c|c|c|}
\hline $\begin{array}{l}\text { Site name } \\
\text { (see fig. 2) }\end{array}$ & Data type & $\begin{array}{l}\text { Number of } \\
\text { samples }\end{array}$ & Dissolved nitrate $^{a}$ & $\begin{array}{l}\text { Dissolved } \\
\text { ammonia }\end{array}$ & $\begin{array}{l}\text { Total Kjeldahl } \\
\text { nitrogen }\end{array}$ & $\begin{array}{c}\text { Dissolved } \\
\text { orthophosphate }\end{array}$ & Total phosphorus & $\begin{array}{c}\text { Total bioreactive } \\
\text { iron }\end{array}$ \\
\hline & & & $4.0-9.5$ & $<3.0-28.8$ & $243-373$ & $<1.0-1.2$ & $10.8-20.5$ & $56.4-366.6$ \\
\hline \multirow[t]{2}{*}{ Echo Creek (site 23) } & & 8 & 8.9 & 5.2 & 116 & 1.0 & 6.9 & 42.7 \\
\hline & & & $2.3-13.7$ & $<3.0-16.1$ & 86-192 & $<1.0-2.0$ & $3.1-13.2$ & $17.0-96.4$ \\
\hline \multirow[t]{2}{*}{ Taylor Creek (site 22) } & & 7 & 9.7 & 7.8 & 80 & $<1.0$ & 6.0 & 27.4 \\
\hline & & & $2.4-29.7$ & $<3.0-98.7$ & $44-264$ & $<1.0-14.1$ & $3.7-29.5$ & $16.4-75.5$ \\
\hline \multirow[t]{2}{*}{ Marlette Creek (site 25) } & & 7 & 37.7 & 5.4 & 261 & 2.9 & 19.3 & 284.0 \\
\hline & & & $14.5-71.8$ & $<3.0-13.5$ & $117-1,580$ & $1.9-4.7$ & $8.2-77.8$ & $68.6-2,247$ \\
\hline \multirow[t]{2}{*}{ All lake samples } & & 81 & 4.8 & 6.1 & 120 & $<1.0$ & 5.5 & 33.7 \\
\hline & & & $<2.0-47.4$ & $<3.0-28.8$ & $<35-892$ & $<1.0-3.0$ & $2.1-60.4$ & $6.1-7,436$ \\
\hline \multirow[t]{2}{*}{ All stream samples } & & 22 & 11.0 & 5.4 & 120 & 1.9 & 8.6 & 72.4 \\
\hline & & & $2.3-71.8$ & $<3.0-98.7$ & $44-1,580$ & $<1.0-14.1$ & $3.1-77.8$ & $16.4-2,247$ \\
\hline
\end{tabular}

${ }^{\mathrm{a}}$ Nitrate results include all oxidized forms of nitrogen (nitrate plus nitrite) as determined by the hydrazine method.

${ }^{b}$ Median values are those of a reduced number of samples: 14 samples.

${ }^{\mathrm{c}}$ Median values are those of a reduced number of samples: 6 samples.

${ }^{\mathrm{d}}$ Median values are those of a reduced number of samples: 15 samples.

${ }^{\mathrm{e}}$ Median values are those of a reduced number of samples: 7 samples.

${ }^{f}$ Median values are those of a reduced number of samples: 9 samples.

${ }^{\mathrm{g}}$ Median values are those of a reduced number of samples: 4 samples.

${ }^{\mathrm{h}}$ Median values are those of a reduced number of samples: 10 samples.

${ }^{\mathrm{i}}$ Median values are those of a reduced number of samples: 5 samples. 
Table 4. Median nutrient concentrations for samples collected from Lower and Upper Echo, Fallen Leaf, Spooner, and Marlette Lakes from previous studies and this study

[Abbreviations: e, epilimnion; h, hypolimnion; TRPA, Tahoe Research Planning Agency; USGS, U.S. Geological Survey; --, placeholder; $<$, less than. Reported nitrate concentrations are the sum of nitrate and nitrite]

\begin{tabular}{|c|c|c|c|c|c|c|}
\hline Year(s) data collected: & $1974-75$ & 1991-92 & 1991-92 & 1994 & 1997-98 & 2002-03 \\
\hline Reference: & Fuller (1975) & Sater (1994) & USGS $^{a}$ & TRPA $^{\mathrm{b}}$ & USGS $^{c}$ & in this report \\
\hline \multicolumn{7}{|l|}{ Lower Echo Lake: } \\
\hline Nitrate $(\mu \mathrm{g} / \mathrm{L}$ as $\mathrm{N})$ & -- & -- & 3 & 1 & 2.9 & 4.8 \\
\hline Ammonia $(\mu \mathrm{g} / \mathrm{L}$ as $\mathrm{N})$ & -- & -- & 3.5 & 5.5 & 1.5 & 5.6 \\
\hline Total Kjeldahl nitrogen ( $\mu \mathrm{g} / \mathrm{L}$ as $\mathrm{N})$ & -- & -- & 118 & 122 & 74 & 108 \\
\hline Orthophosphate $(\mu \mathrm{g} / \mathrm{L}$ as $\mathrm{P})$ & -- & -- & 1 & 1 & -- & $<1$ \\
\hline Total phosphorus ( $\mu \mathrm{g} / \mathrm{L}$ as $\mathrm{P})$ & -- & -- & 6 & 6 & -- & 4.5 \\
\hline Bioreactive iron $(\mu \mathrm{g} / \mathrm{L}$ as $\mathrm{Fe})$ & -- & -- & 26 & -- & 21 & 19.3 \\
\hline
\end{tabular}

Upper Echo Lake:

\begin{tabular}{|c|c|c|c|c|c|c|}
\hline Nitrate $(\mu \mathrm{g} / \mathrm{L}$ as $\mathrm{N})$ & -- & -- & 3 & 1 & -- & 5.6 \\
\hline Ammonia $(\mu \mathrm{g} / \mathrm{L}$ as $\mathrm{N})$ & -- & -- & 6.5 & 5 & -- & 6.1 \\
\hline 1 nitrogen $(\mu \mathrm{g} / \mathrm{L}$ as $\mathrm{N})$ & -- & -- & 112 & 143 & -- & 116 \\
\hline phosphate ( $\mu \mathrm{g} / \mathrm{L}$ as $\mathrm{P})$ & -- & -- & 1.5 & 1 & -- & $<1$ \\
\hline hosphorus ( $\mu \mathrm{g} / \mathrm{L}$ as $\mathrm{P})$ & -- & -- & 6 & 9 & -- & 5.4 \\
\hline ctive iron ( $\mu \mathrm{g} / \mathrm{L}$ as $\mathrm{Fe})$ & -- & -- & 33 & -- & -- & 33.4 \\
\hline
\end{tabular}

Fallen Leaf Lake:

$$
\begin{array}{r}
\text { Nitrate }(\mu \mathrm{g} / \mathrm{L} \text { as } \mathrm{N}) \\
\text { Ammonia }(\mu \mathrm{g} / \mathrm{L} \text { as } \mathrm{N}) \\
\text { Total Kjeldahl nitrogen }(\mu \mathrm{g} / \mathrm{L} \text { as } \mathrm{N}) \\
\text { Orthophosphate }(\mu \mathrm{g} / \mathrm{L} \text { as } \mathrm{P}) \\
\text { Total phosphorus }(\mu \mathrm{g} / \mathrm{L} \text { as } \mathrm{P}) \\
\text { Bioreactive iron }(\mu \mathrm{g} / \mathrm{L} \text { as } \mathrm{Fe})
\end{array}
$$

1.5
5
$530(\mathrm{~h}), 90(\mathrm{e})$
$2(\mathrm{~h}), 3(\mathrm{e})$
$9(\mathrm{~h}), 9(\mathrm{e})$
${ }^{3} 20$

$\begin{array}{lr}-- & 2 \\ -- & 4 \\ -- & 76 \\ -- & 2 \\ -- & 8 \\ -- & 6\end{array}$

1
5
76
1
5
--

2.9

4

$3.2 \quad 6.2$

\begin{tabular}{|c|c|c|c|c|c|c|}
\hline Nitrate $(\mu \mathrm{g} / \mathrm{L}$ as $\mathrm{N})$ & -- & 3 & 3 & -- & -- & 5 \\
\hline Ammonia $(\mu \mathrm{g} / \mathrm{L}$ as $\mathrm{N})$ & -- & 6 & 11.5 & -- & -- & 5.6 \\
\hline Total Kjeldahl nitrogen $(\mu \mathrm{g} / \mathrm{L}$ as $\mathrm{N})$ & -- & 644 & 494 & -- & -- & 548 \\
\hline Orthophosphate $(\mu \mathrm{g} / \mathrm{L}$ as $\mathrm{P})$ & -- & 5 & 2.5 & -- & -- & $<1$ \\
\hline Total phosphorus ( $\mu \mathrm{g} / \mathrm{L}$ as $\mathrm{P})$ & -- & 21 & 17 & -- & -- & 18.5 \\
\hline Bioreactive iron $(\mu \mathrm{g} / \mathrm{L}$ as $\mathrm{Fe})$ & -- & 90 & 100 & -- & -- & 150 \\
\hline \multicolumn{7}{|l|}{ rlette Lake: } \\
\hline Nitrate $(\mu \mathrm{g} / \mathrm{L}$ as $\mathrm{N})$ & -- & 4 & 64 & -- & 3.8 & 5 \\
\hline Ammonia $(\mu \mathrm{g} / \mathrm{L}$ as $\mathrm{N})$ & -- & 16 & 52 & -- & 11 & 8.1 \\
\hline Total Kjeldahl nitrogen $(\mu \mathrm{g} / \mathrm{L}$ as $\mathrm{N})$ & -- & 420 & 344 & -- & 217 & 254 \\
\hline Orthophosphate $(\mu \mathrm{g} / \mathrm{L}$ as $\mathrm{P})$ & -- & 7 & 3.5 & -- & 11 & $<1$ \\
\hline Total phosphorus ( $\mu \mathrm{g} / \mathrm{L}$ as $\mathrm{P})$ & -- & 14 & 20 & -- & 27 & 10.8 \\
\hline Bioreactive iron $(\mu \mathrm{g} / \mathrm{L}$ as $\mathrm{Fe})$ & -- & 190 & 96 & -- & 155 & 56.4 \\
\hline
\end{tabular}

$190 \quad 73$

$--<1$

$\begin{array}{ll}-- & 3.8\end{array}$

$21 \quad 8.5$

\section{Spooner Lake:}

${ }^{\mathrm{a}}$ Hill (1992).

${ }^{\mathrm{b}}$ Reuter and others (1996).

${ }^{c}$ U.S. Geological Survey (2004). 
Taylor Creek had the highest median and the highest observed ammonia concentration $(98.7 \mu \mathrm{g} / \mathrm{L}$ as $\mathrm{N})$ found during this study. The high concentration of ammonia in the sample from Taylor Creek was taken during the annual die-off of kokanee salmon, which may have contributed to the high concentration.

TKN concentrations generally were low in Upper and Lower Echo and Fallen Leaf Lakes (median concentration ranges from 73 to $116 \mu \mathrm{g} / \mathrm{L}$ as N). Spooner and Marlette Lakes had higher median concentrations of 548 and $254 \mu \mathrm{g} / \mathrm{L}$ as N, respectively. The maximum measured TKN concentration was $892 \mu \mathrm{g} / \mathrm{L}$ as $\mathrm{N}$ in a sample from Spooner Lake. The median TKN concentration in the hypolimnion was higher than that in the epilimnion in all lakes except for Fallen Leaf Lake (table 3). Median concentrations of TKN in samples from the streams ranged from 80 to $261 \mu \mathrm{g} / \mathrm{L}$ as N, with Marlette Creek having the highest median.

DOP concentrations were low in all lake samples. Median concentration for all lakes was less than $1.0 \mu \mathrm{g} / \mathrm{L}$ as $\mathrm{P}$, with Spooner Lake having the highest measured concentration of 3.0 $\mu \mathrm{g} / \mathrm{L}$ as $\mathrm{P}$ (table 3 ). The median DOP concentrations in the hypolimnion and the epilimnion had no difference. Streams generally had DOP concentrations slightly greater than the lakes with medians ranging from less than 1.0 to $2.9 \mu \mathrm{g} / \mathrm{L}$ as $\mathrm{P}$. The highest measured DOP concentration was in a sample from Taylor Creek (14.1 $\mu \mathrm{g} / \mathrm{L}$ as P).

TP concentrations were less than $8 \mu \mathrm{g} / \mathrm{L}$ as $\mathrm{P}$ in all samples from Upper and Lower Echo and Fallen Leaf Lakes. Median concentrations at these three lakes were between 3.8 and $5.4 \mu \mathrm{g} /$ $\mathrm{L}$ as $\mathrm{P}$ (table 3 ). Much higher concentrations of TP were found in Spooner and Marlette Lakes, with median values of 18.5 and $10.8 \mu \mathrm{g} / \mathrm{L}$ as $\mathrm{P}$, respectively. Median TP concentrations were slightly higher in the hypolimnion than in the epilimnion for Upper and Lower Echo and Fallen Leaf Lakes. For Spooner and Marlette Lakes, the median concentration of TP in the hypolimnion was about twice that of the epilimnion (table 3). Median concentrations of TP in stream samples were slightly higher than those for the lakes and ranged from 6.0 to $19.3 \mu \mathrm{g} / \mathrm{L}$ as $\mathrm{P}$. Marlette Creek had the highest observed concentration of TP in a stream sample $(77.8 \mu \mathrm{g} / \mathrm{L}$ as $\mathrm{P})$.

TFe concentrations generally were low in Upper and Lower Echo and Fallen Leaf Lakes with median concentrations ranging from 8.5 to $33.4 \mu \mathrm{g} / \mathrm{L}$ (table 3 ; app. B). Spooner and Marlette Lakes had TFe concentrations that generally were higher than those at the other lakes. Median concentrations of $\mathrm{TFe}$ in Spooner and Marlette Lakes were 150 and $56.4 \mu \mathrm{g} / \mathrm{L}$, respectively. Some relatively high concentrations (995.2 and $7,436 \mu \mathrm{g} / \mathrm{L}$ ) were found in samples from Spooner Lake. Median concentrations of TFe in the hypolimnion of all lakes, except Fallen Leaf Lake, were greater than those from the epilimnion. TFe concentrations were low in the streams on the west side of Lake Tahoe (Echo and Taylor Creeks) with medians of 42.7 and $27.4 \mu \mathrm{g} / \mathrm{L}$, respectively. Marlette Creek had the highest median TFe concentration $(284 \mu \mathrm{g} / \mathrm{L})$ of any stream and had a maximum observed concentration of 2,247 $\mu \mathrm{g} / \mathrm{L}$ (table 3; app. C).

\section{REFERENCES CITED}

Brzezinski, M.A., 1987, Colorimetric determination of nanomolar concentrations of ammonium in seawater using solvent extraction: Marine Chemistry, v. 20, p. 277-288.

Childress, C.J.O., Foreman, W.T., Connor, B.F., and Maloney, T.J., 1999, New reporting procedures based on long-term method detection levels and some considerations for interpretations of water-quality data provided by the U.S. Geological Survey National Water Quality Laboratory: U.S. Geological Survey Open-File Report 99-193, 19 p.

Eaton, A.D., Clesceri, L.S., and Greenberg, A.E., eds., 1995, Standard methods for the examination of water and wastewater, 19th edition: American Public Health Association, Washington D.C., various pagination.

Fishman, M.J., and Friedman, L.C., eds., 1985, Methods for the determination of inorganic substances in water and fluvial sediments: U.S. Geological Survey Open-File Report 85-495, $709 \mathrm{p}$.

Fuller, R.H., 1975, Selected water-quality data from Fallen Leaf Lake, El Dorado County, California, June through October 1974: U.S. Geological Survey Open-File Report, 38 p.

Goldman, C.R., Reuter, J.E., Jassby, A.D., Kavvas, M.L., and Schladow, G., 1998, An integrated watershed approach to evaluate and model ecosystem effects of erosion and pollutant transport in urbanized subalpine landscapes: Annual Progress Report - 1998, Lake Clarity and Watershed Modeling Presidential Deliverable, Tahoe Research Group, University of California, Davis, CA, p. 1-4.

Hill, K.J., 1992, 1992 Annual water quality report: Zephyr Cove, NV, Tahoe Regional Planning Agency, 105 p.

Hill, K.J., 1996, Water quality report for the water year 1995: Zephyr Cove, NV, Tahoe Regional Planning Agency, 115 p.

Kamphake, L.J., Hannah, S.A., and Cohen, J.M., 1967, Automated analysis for nitrate by Hydrazine reduction method: Water Research, v. 1, issue 3, p. 205-216.

Kempers, A.J., and Luft, A.G., 1988, Re-examination of the determination of environmental nitrate as nitrite by reduction with hydrazine: The Analyst, v. 113(7), p. 1117-1120.

Landers, D.H., Eilers, J.M., Brakke, D.F., Overton, W.S., Kellar, P.E., Silverstein, M.E., Schonbrod, R.D., Crowe, R.E., Linthurst, R.A., Omernik, J.M., Teague, S.A., and Meier, E.P., 1987, Characteristics of lakes in the western United States. Volume 1, Population descriptions and physico-chemical relationships: Washington, D.C., U.S. Environmental Protection Agency, EPA-600/3-86/054a, 176 p.

Murphy, J., and Riley, J.P., 1962, A modified single solution method for the determination of phosphate in natural waters: Analytica Chimica Acta, v. 27, p. 31-36.

Preissler, A.M., Roach, G.A., Thomas, K.A., and Wilson, J.W., 1999, Water resources data, Nevada, water year 1998: U.S. Geological Survey Water-Data Report NV-98-1, 598 p. 
Reuter, J.E., Palmer, M.D., and Goldman, C.R., 1996, Limnology and trophic status of Lower Echo Lake, Upper Echo Lake, and Fallen Leaf Lake: University of California, Davis, Tahoe Research Group, 134 p.

Rowe, T.G., Saleh, D.K., Watkins, S.A., and Kratzer, C.R., 2002, Streamflow and water-quality data for selected watersheds in the Lake Tahoe Basin, California and Nevada, through September 1998: U.S. Geological Survey WaterResources Investigations Report 02-4030, 118 p.

Sater, E.M., 1994, Seasonal nutrient limitation at four high altitude, shallow reservoirs of the Tahoe Basin and northern Nevada: Thesis (M.S.) University of California, Davis, CA; Tahoe Research Group, Davis, CA, 258 p.

Smith, J.L., Stone, J.C., Rowe, T.G., and Gardner, J.V., 1999, Selected hydrologic features of Lake Tahoe Basin and surrounding area, California and Nevada, 1998: U.S. Geological Survey Open-File Report 98-649, 1 sheet.

State of California, 1962, Lake Tahoe Basin water quality survey, 1961: State of California, Department of Public
Health, Bureau of Sanitary Engineering, Sacramento, CA, 121 p. plus appendices.

Stookey, L.L., 1970, Ferrozine - A new spectrophotometric reagent for iron: Analytical Chemistry, v. 42, no. 7, p. 779781.

Strickland, J.D.H., and Parsons, T.R., 1972, A practical handbook of seawater analysis: Bulletin 167, Fisheries Research Board of Canada, Ottawa, Ontario, Canada, 310 p.

U.S. Geological Survey, 1997 to present, National field manual for the collection of water-quality data: U.S. Geological Survey Techniques of Water-Resources Investigations, book 9, chaps. A1-A9, 2 v., variously paged. Chapters originally were published from 1997-99; updates and revisions are ongoing and are summarized at URL < http://water.usgs.gov/ owq/FieldManual/ mastererrata.html $>$.

U.S. Geological Survey, 2004, NWISWeb data for the Nation: accessed in September 2004 at URL: <http:// nwis.waterdata.usgs.gov/nv/nwis/qwdata $>$. 
16 Nutrients in Upper and Lower Echo, Fallen Leaf, Spooner, and Marlette Lakes and Associated Streams, CA and NV, 2002-03 
Figures 5-7 
18 Nutrients in Upper and Lower Echo, Fallen Leaf, Spooner, and Marlette Lakes and Associated Streams, CA and NV, 2002-03

$A$
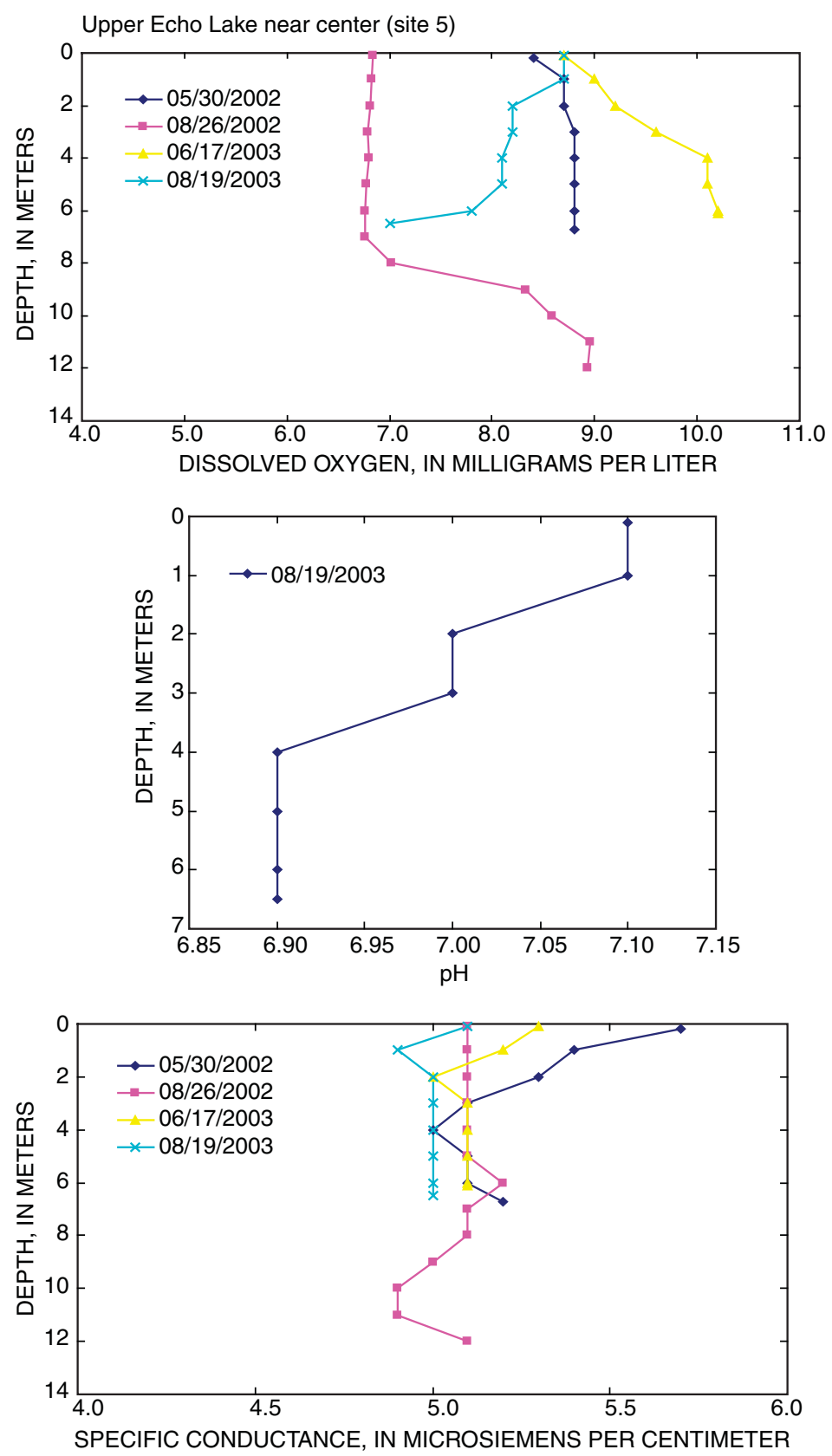

AT 25 DEGREES CELSIUS

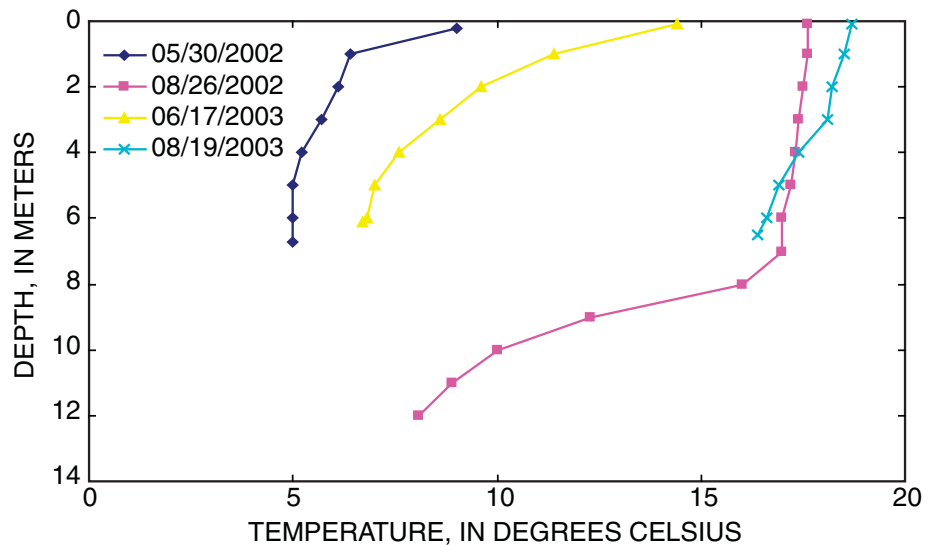

Figure 5. Profiles of field measurements taken in (A) Upper Echo Lake near center (site 5), (B) Lower Echo Lake near center (site 2), (C) Fallen Leaf Lake near center (site 10), (D) Spooner Lake near center (site 14), and (E) Marlette Lake near center (site 19). 
$B$
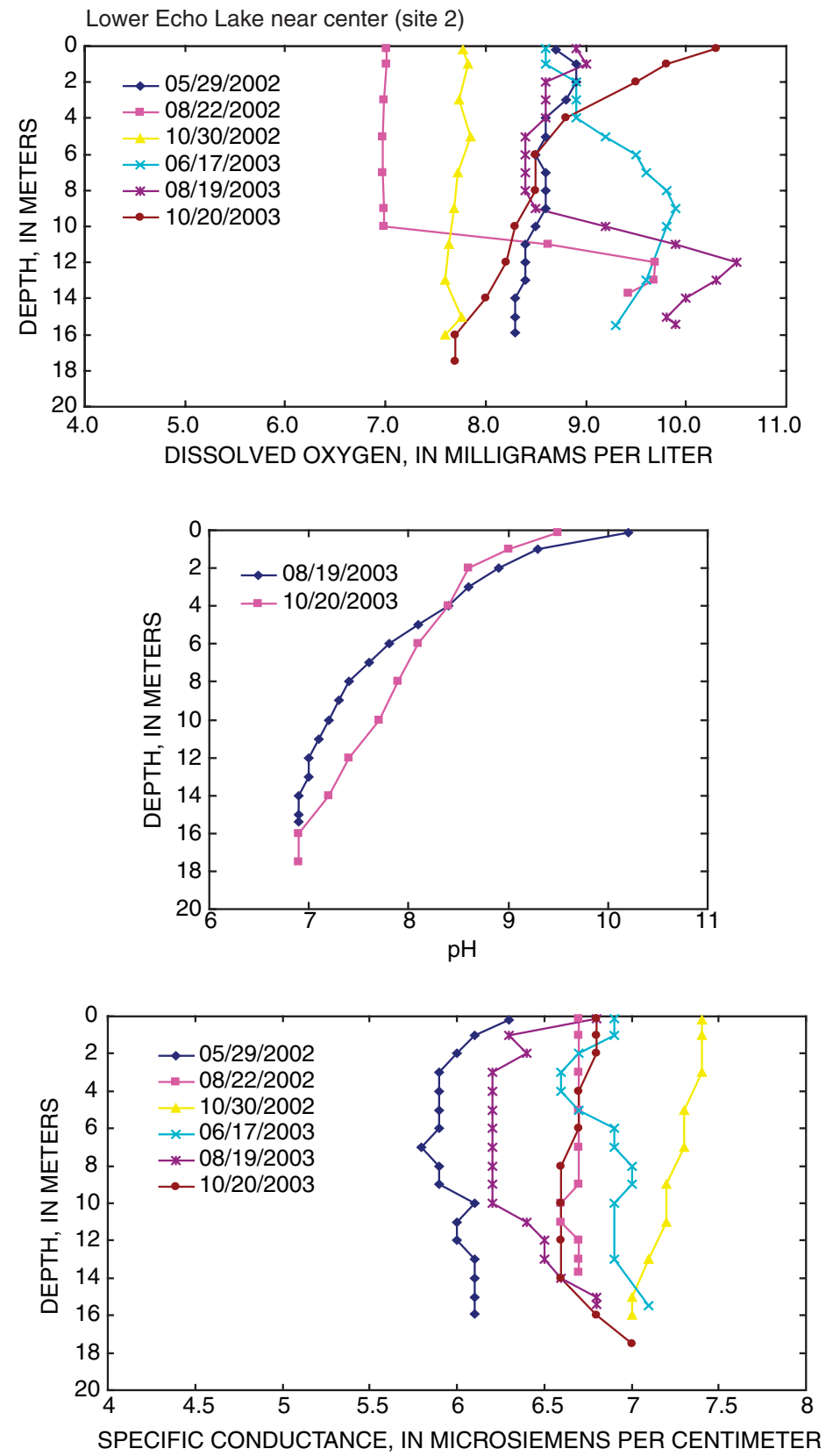
AT 25 DEGREES CELSIUS

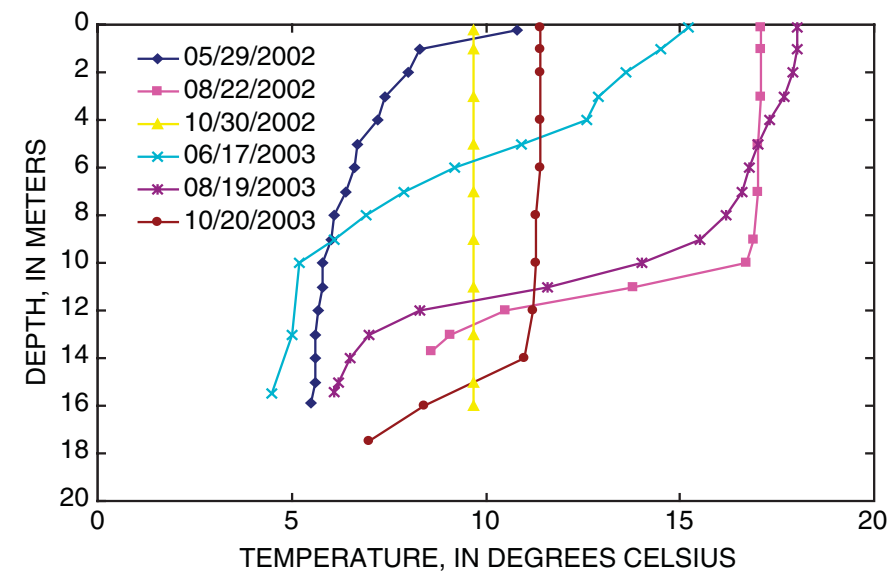

Figure 5. Profiles of field measurements taken in (A) Upper Echo Lake near center (site 5), (B) Lower Echo Lake near center (site 2), (C) Fallen Leaf Lake near center (site 10), (D) Spooner Lake near center (site 14), and (E) Marlette Lake near center (site 19)—Continued. 
20 Nutrients in Upper and Lower Echo, Fallen Leaf, Spooner, and Marlette Lakes and Associated Streams, CA and NV, 2002-03
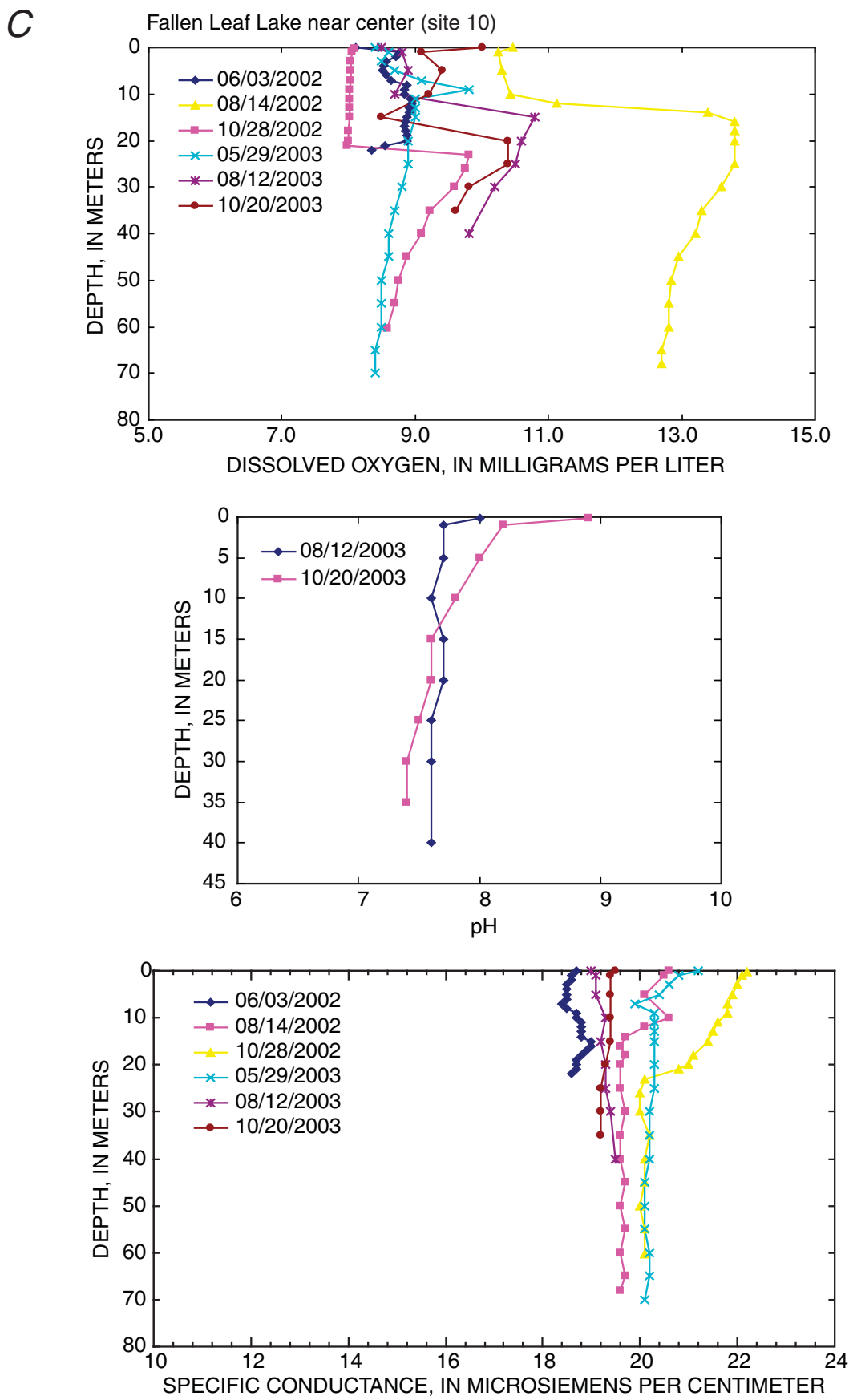

AT 25 DEGREES CELSIUS

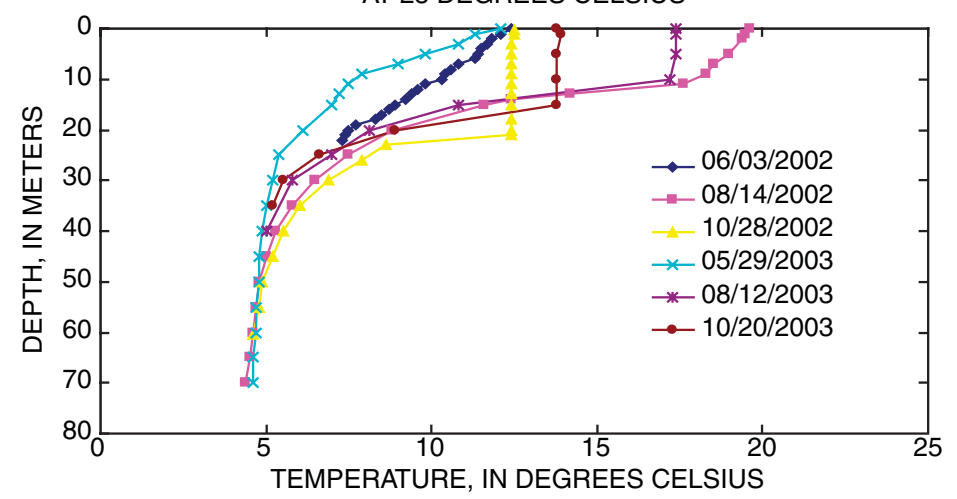

Figure 5. Profiles of field measurements taken in $(A)$ Upper Echo Lake near center (site 5), (B) Lower Echo Lake near center (site 2), (C) Fallen Leaf Lake near center (site 10), (D) Spooner Lake near center (site 14), and (E) Marlette Lake near center (site 19)—Continued. 
$D$
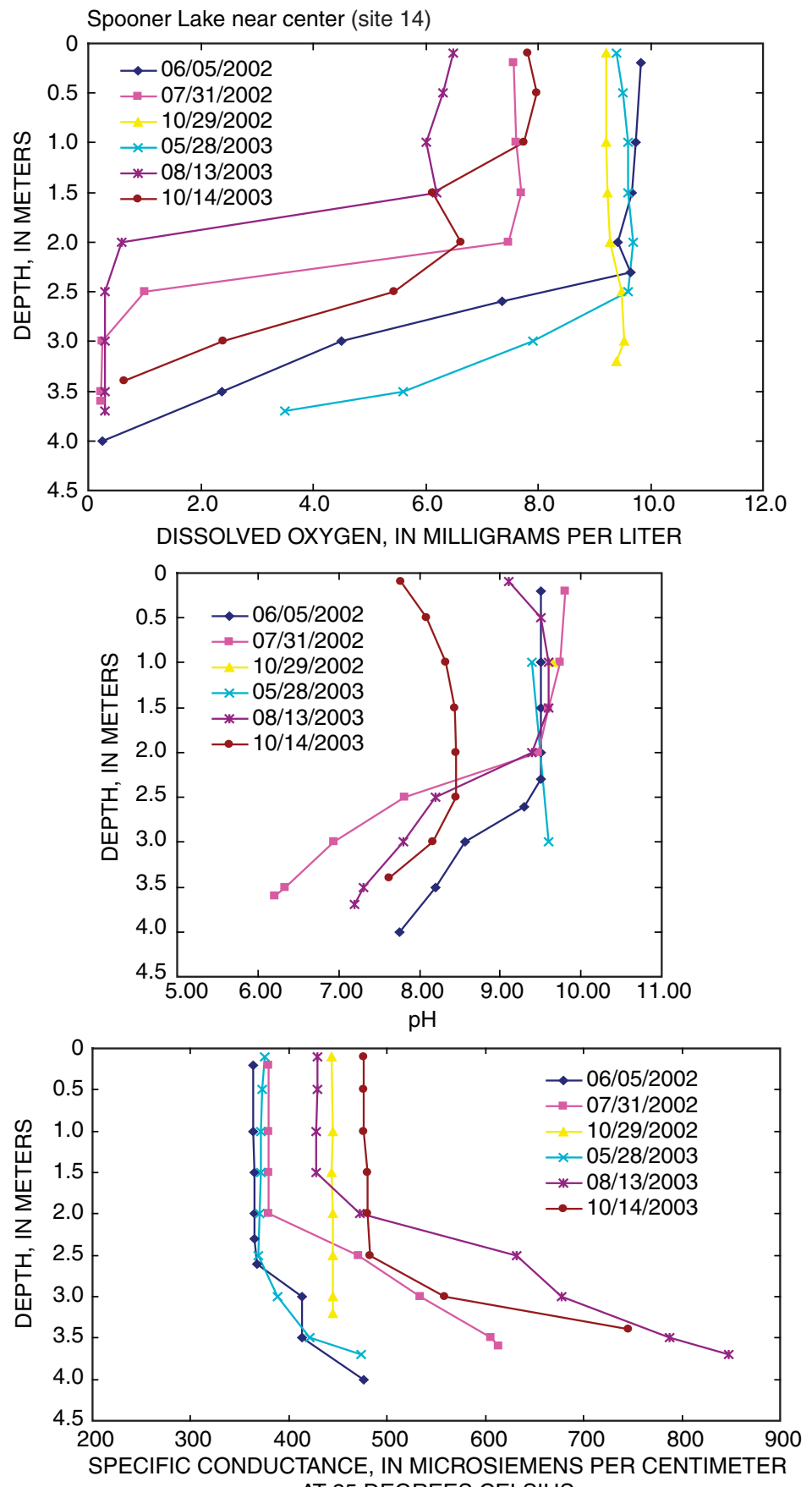

AT 25 DEGREES CELSIUS

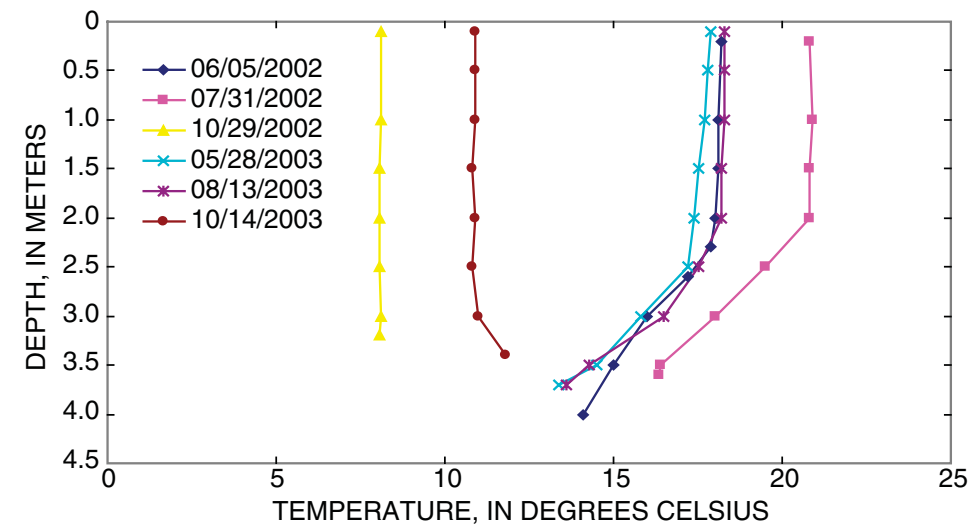

Figure 5. Profiles of field measurements taken in ( $A$ ) Upper Echo Lake near center (site 5), (B) Lower Echo Lake near center (site 2), (C) Fallen Leaf Lake near center (site 10), (D) Spooner Lake near center (site 14), and (E) Marlette Lake near center (site 19)—Continued. 
22 Nutrients in Upper and Lower Echo, Fallen Leaf, Spooner, and Marlette Lakes and Associated Streams, CA and NV, 2002-03

E
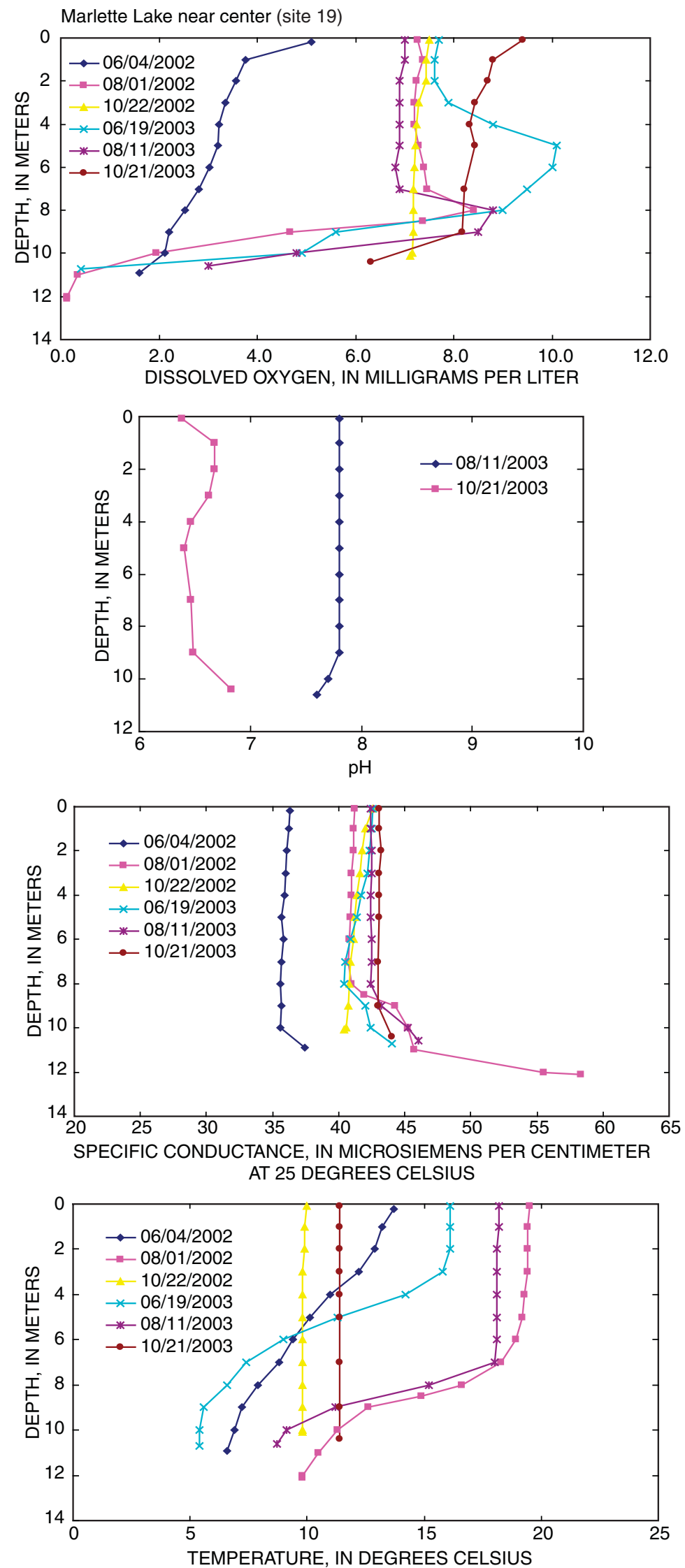

Figure 5. Profiles of field measurements taken in ( $A$ ) Upper Echo Lake near center (site 5), (B) Lower Echo Lake near center (site 2), (C) Fallen Leaf Lake near center (site 10), (D) Spooner Lake near center (site 14), and (E) Marlette Lake near center (site 19)—Continued. 


\section{$A$}

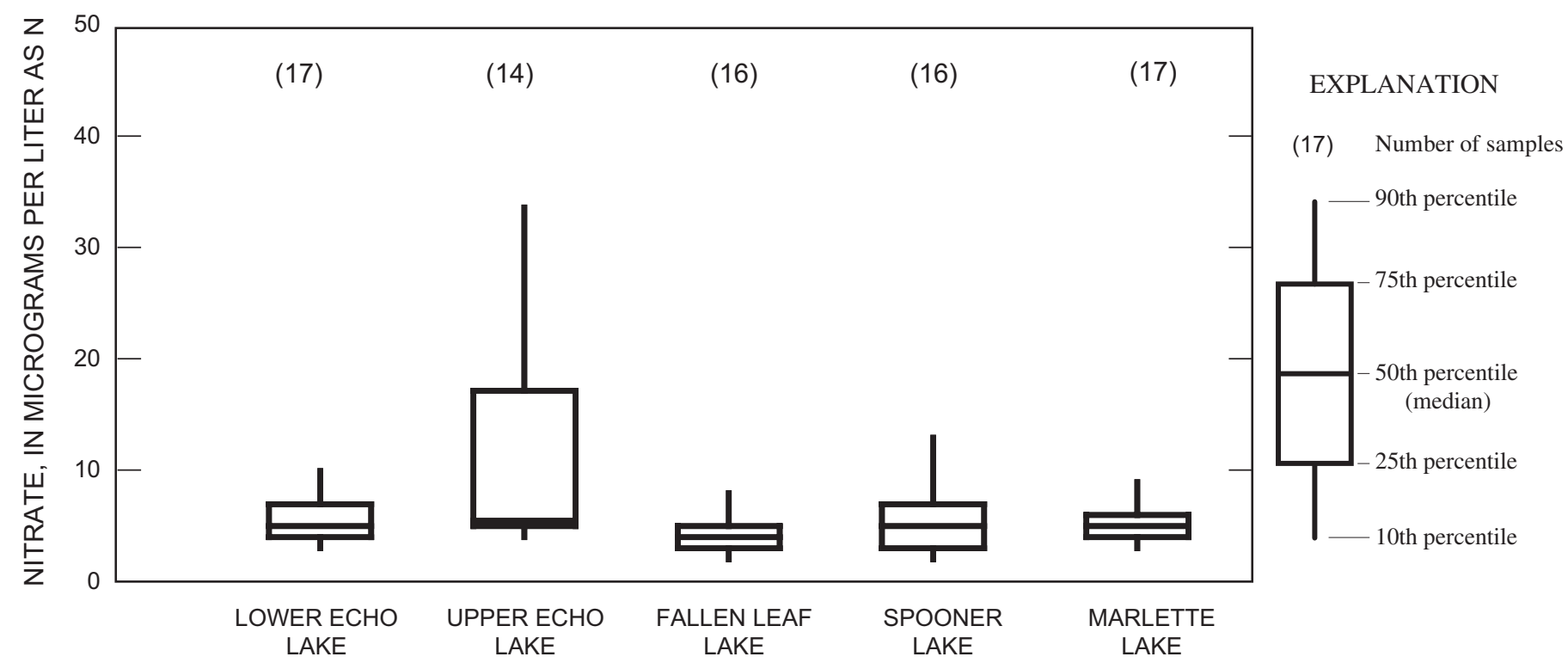

$B$

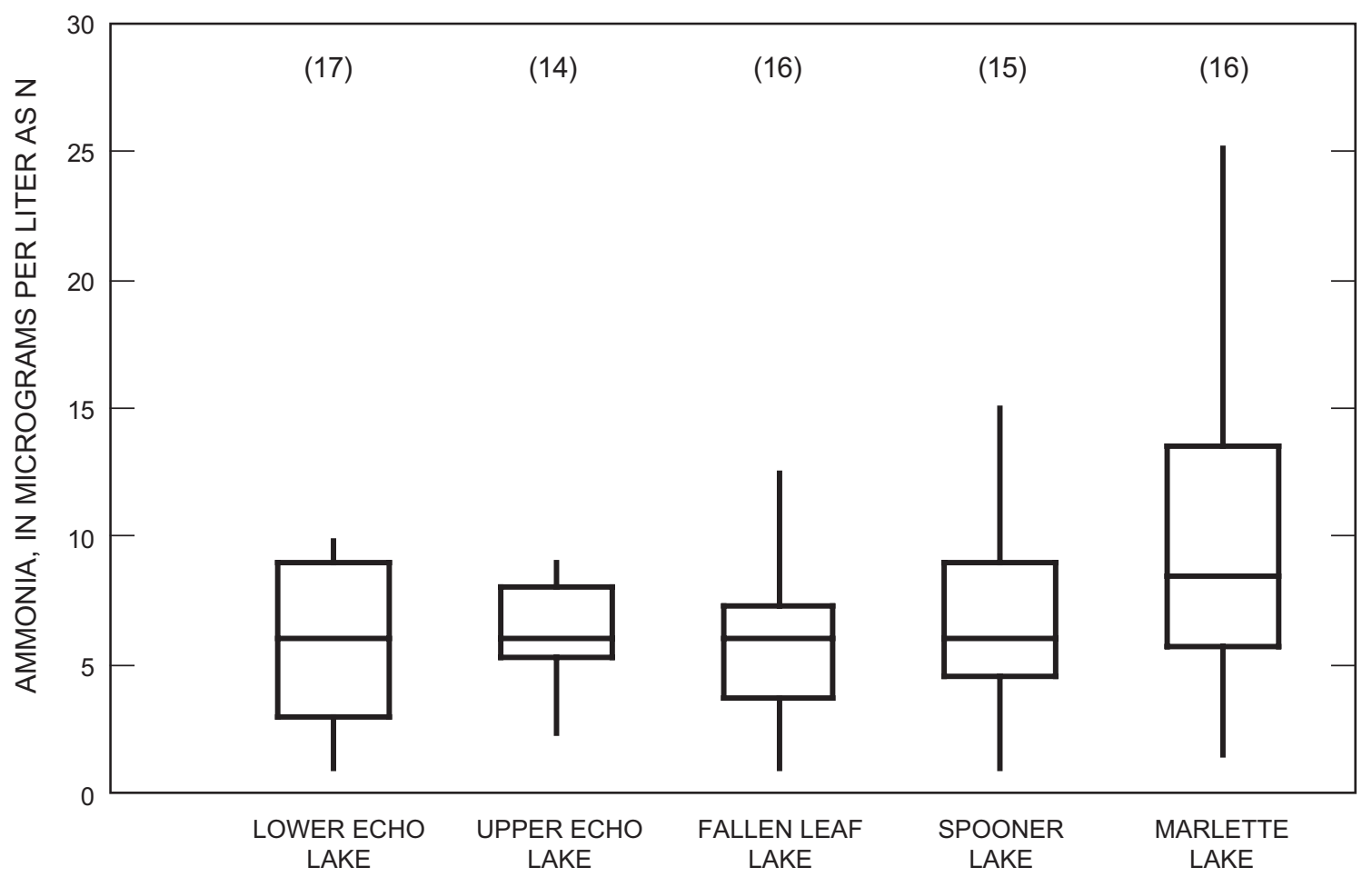

Figure 6. Distribution of nutrient data from Upper and Lower Echo, Fallen Leaf, Spooner, and Marlette Lakes: $(A)$ dissolved nitrate (sum of nitrate plus nitrite), ( $(B)$ dissolved ammonia, $(C)$ total Kjeldahl nitrogen (ammonia plus organic nitrogen), $(D)$ dissolved orthophosphorus (soluble reactive phosphorus), (E) total phosphorus, and ( $\mathrm{A}$ total bioreactive iron. 
C

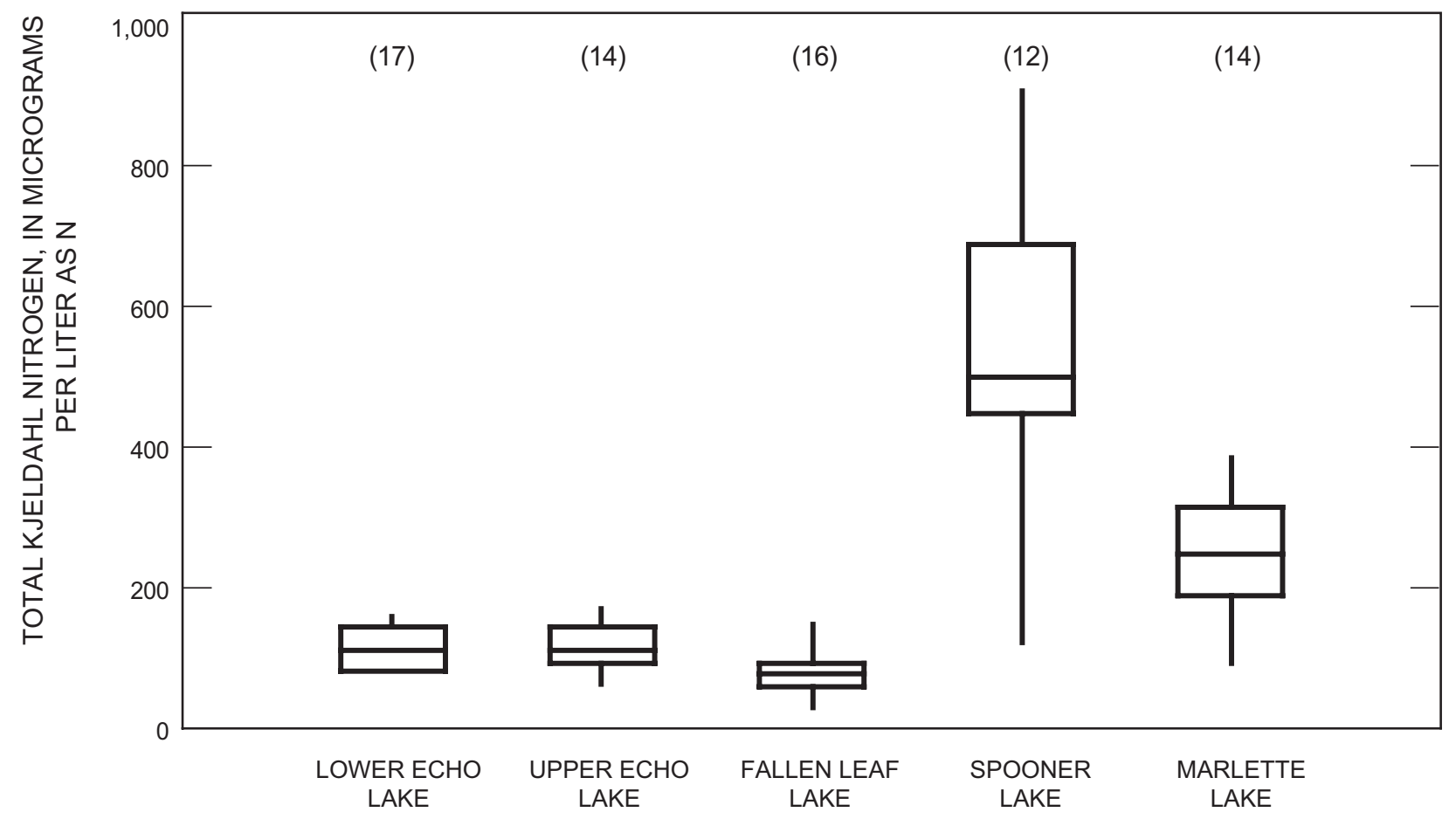

$D$

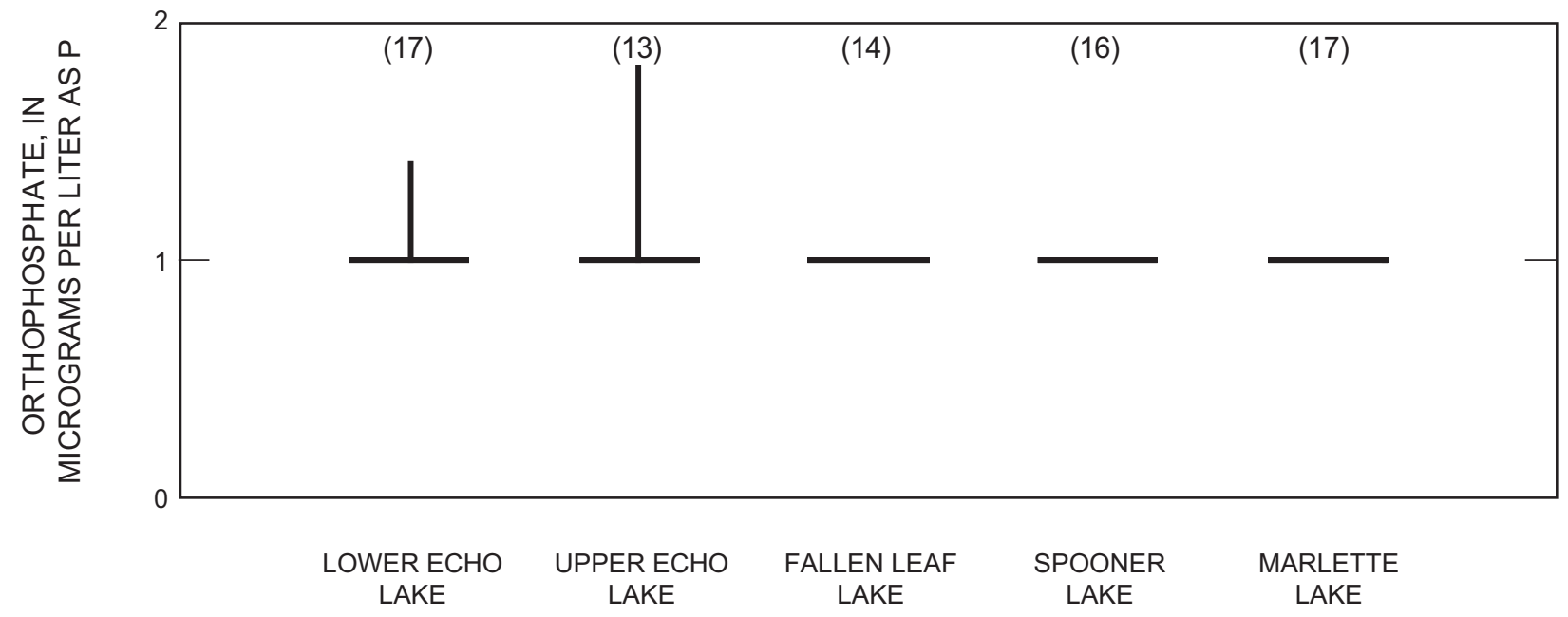

Figure 6. Distribution of nutrient data from Upper and Lower Echo, Fallen Leaf, Spooner, and Marlette Lakes: $(A)$ dissolved nitrate (sum of nitrate plus nitrite), $(B)$ dissolved ammonia, ( $C$ ) total Kjeldahl nitrogen (ammonia plus organic nitrogen), ( $D$ ) dissolved orthophosphorus (soluble reactive phosphorus), (E) total phosphorus, and ( $A$ total bioreactive iron-Continued. 
$E$

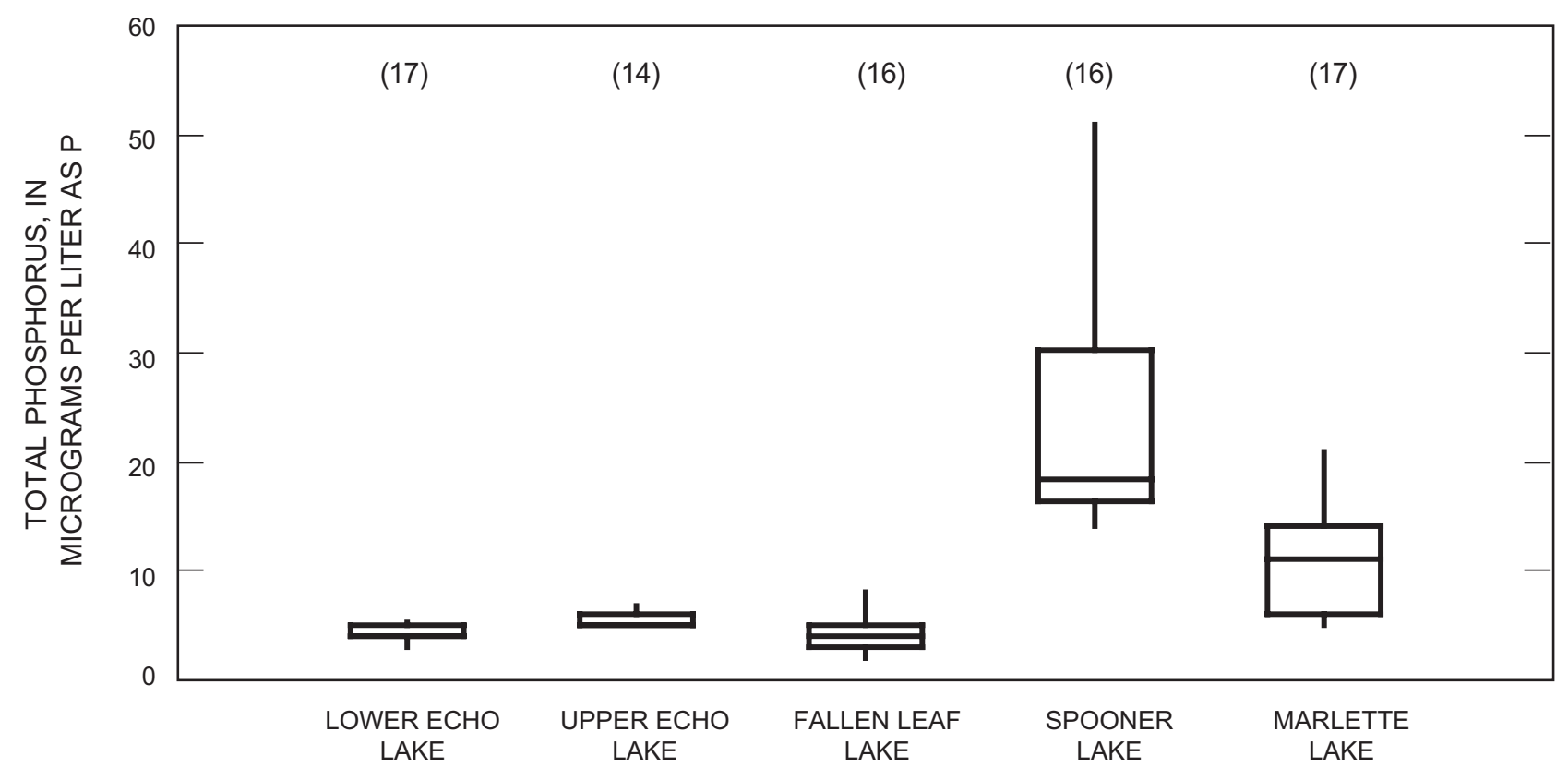

$F$

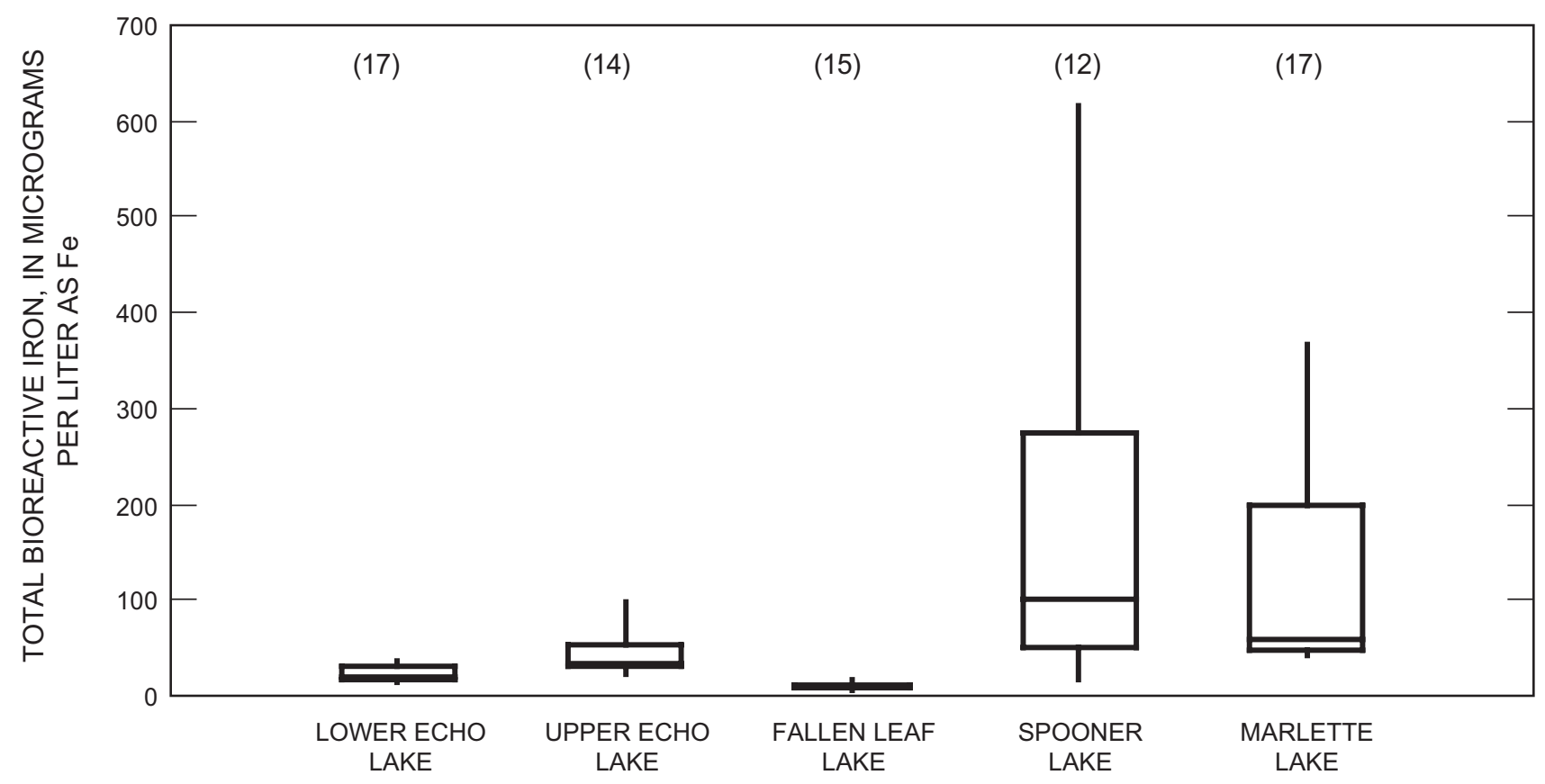

Figure 6. Distribution of nutrient data from Upper and Lower Echo, Fallen Leaf, Spooner, and Marlette Lakes: $(A)$ dissolved nitrate (sum of nitrate plus nitrite), (B) dissolved ammonia, (C) total Kjeldahl nitrogen (ammonia plus organic nitrogen), (D) dissolved orthophosphorus (soluble reactive phosphorus), (E) total phosphorus, and ( $A$ total bioreactive iron — Continued. 
$A$

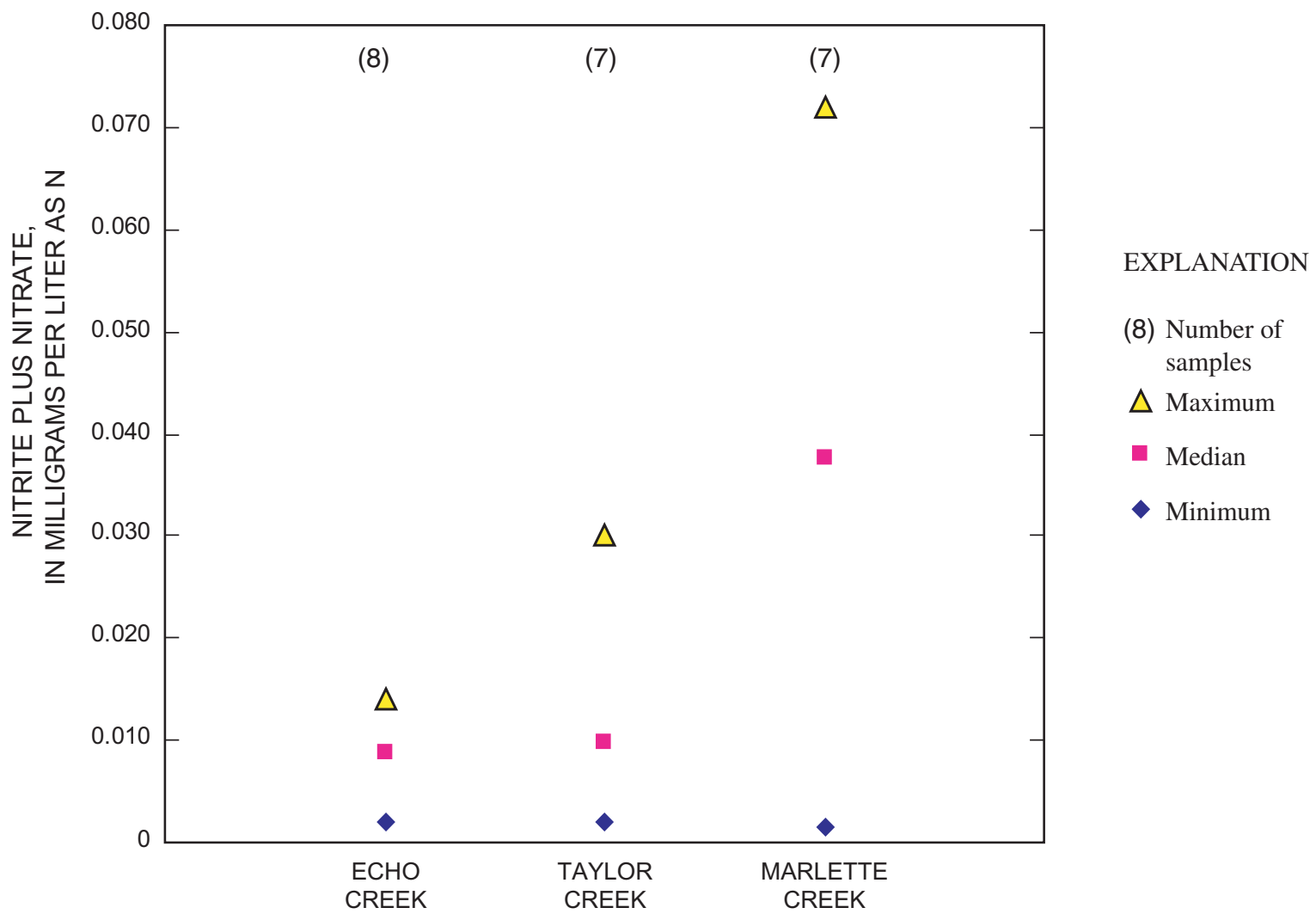

$B$

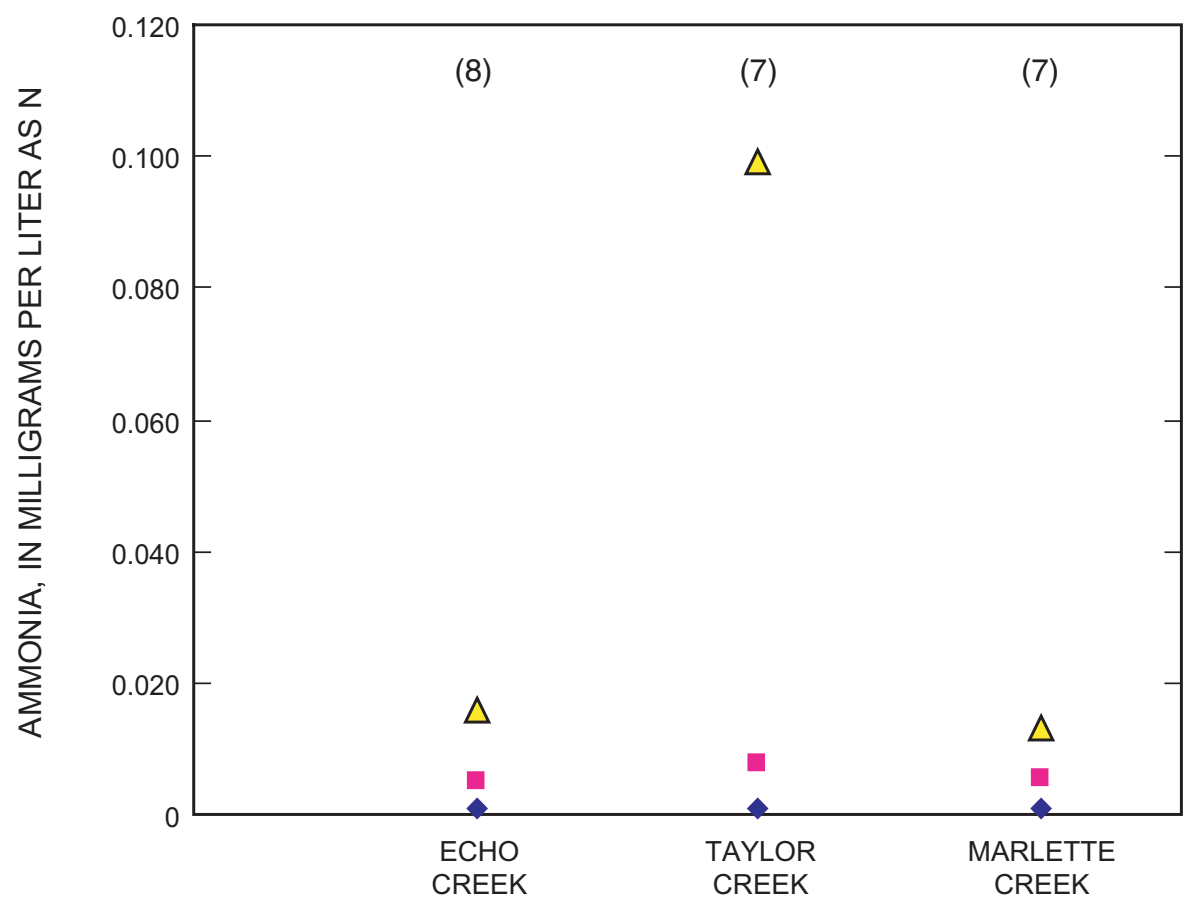

Figure 7. Concentrations of nutrients in samples from Echo, Taylor, and Marlette Creeks: $(A)$ dissolved nitrate (sum of nitrate plus nitrite), $(B)$ dissolved ammonia, (C) total Kjeldahl nitrogen (ammonia plus organic nitrogen), (D) dissolved orthophosphorus (soluble reactive phosphorus), (E) total phosphorus, and ( $A$ total bioreactive iron. 


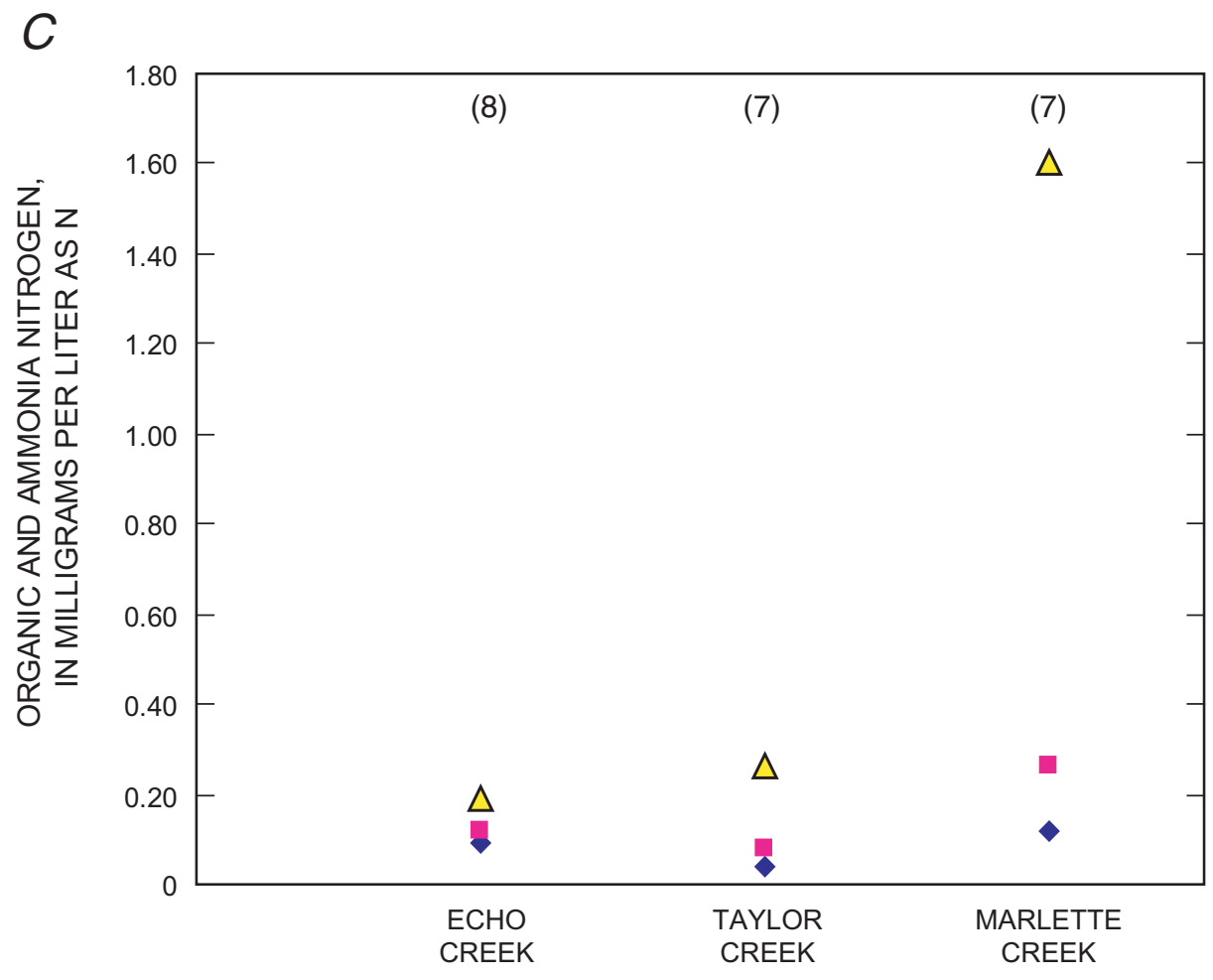

$D$

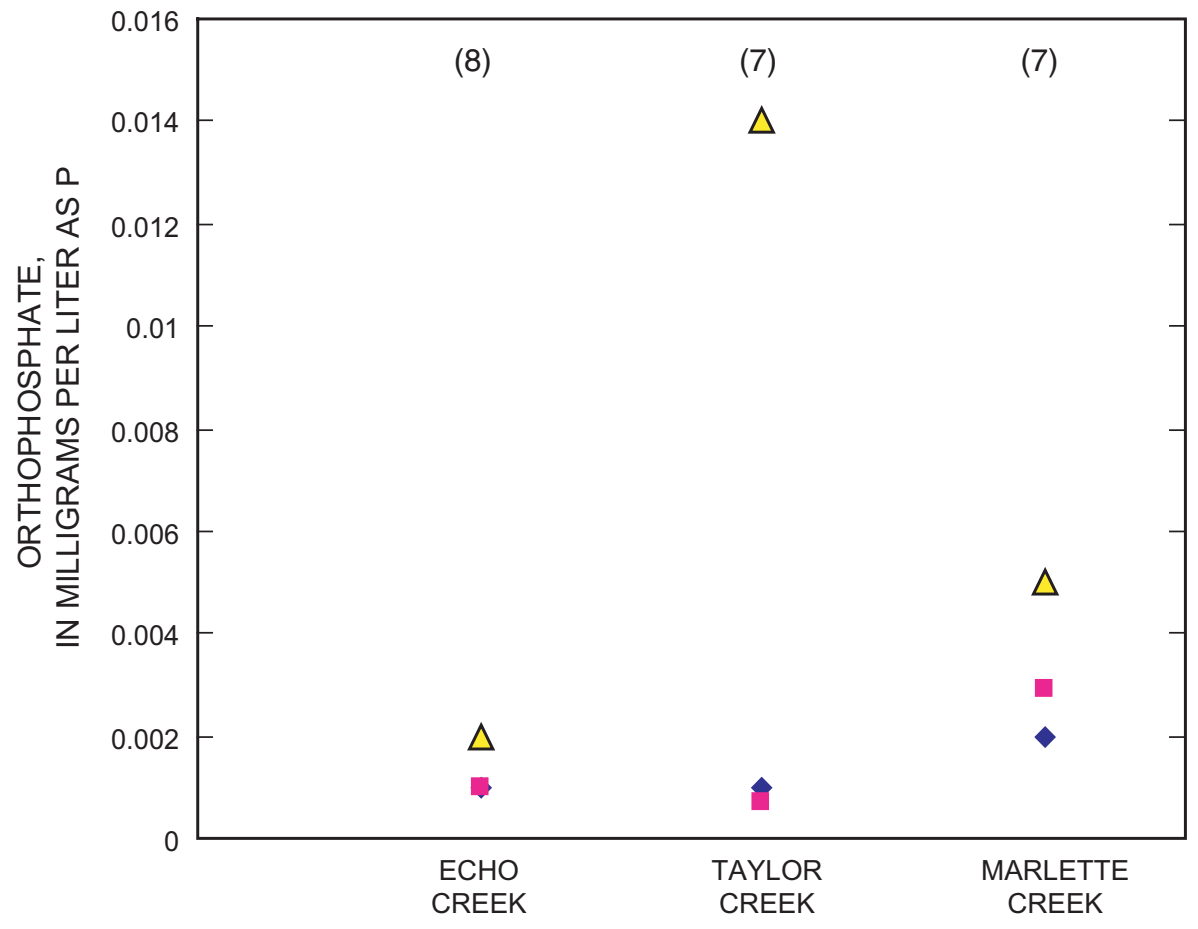

Figure 7. Concentrations of nutrients in samples from Echo, Taylor, and Marlette Creeks: (A) dissolved nitrate (sum of nitrate plus nitrite), (B) dissolved ammonia, ( $C$ ) total Kjeldahl nitrogen (ammonia plus organic nitrogen), ( $D$ ) dissolved orthophosphorus (soluble reactive phosphorus), (E) total phosphorus, and ( $A$ total bioreactive iron - Continued. 
$E$

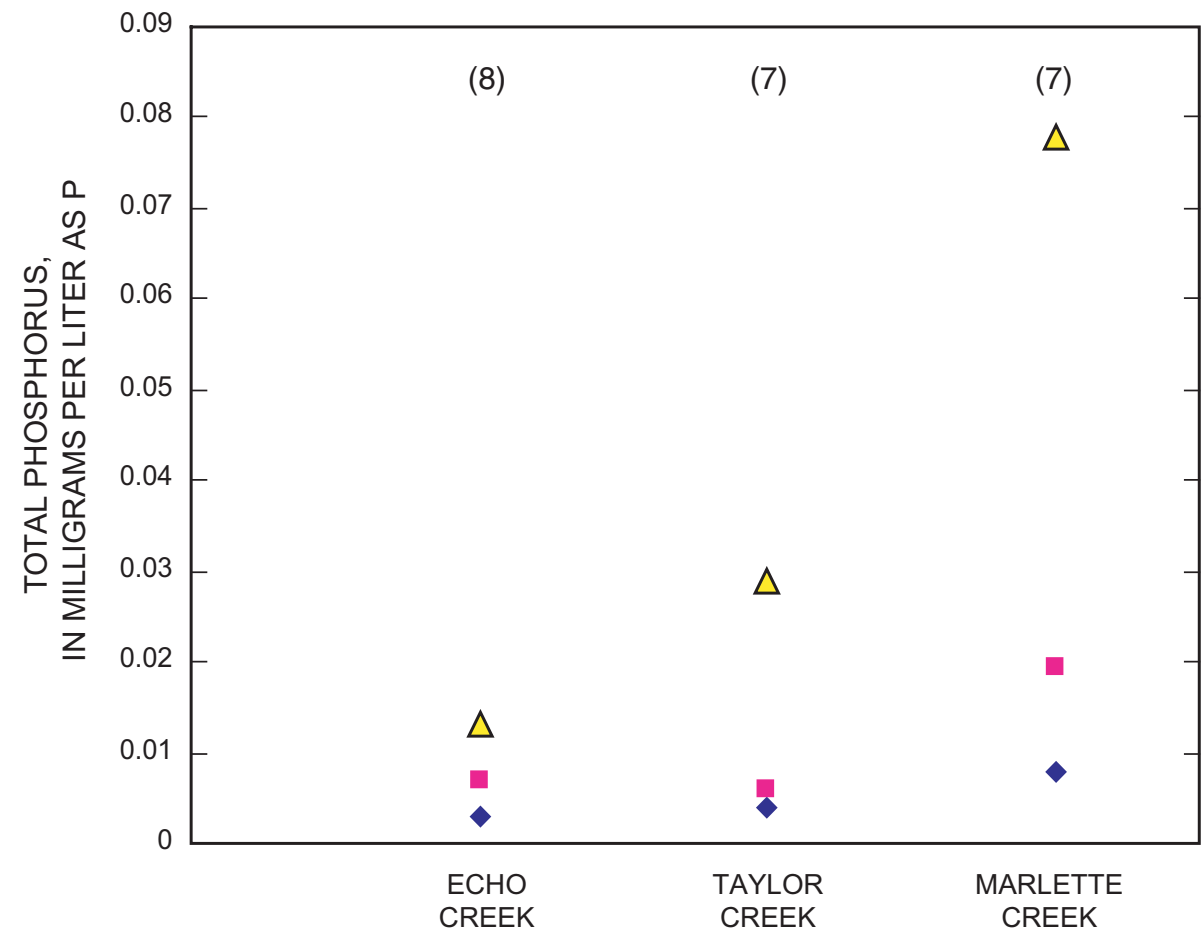

$F$

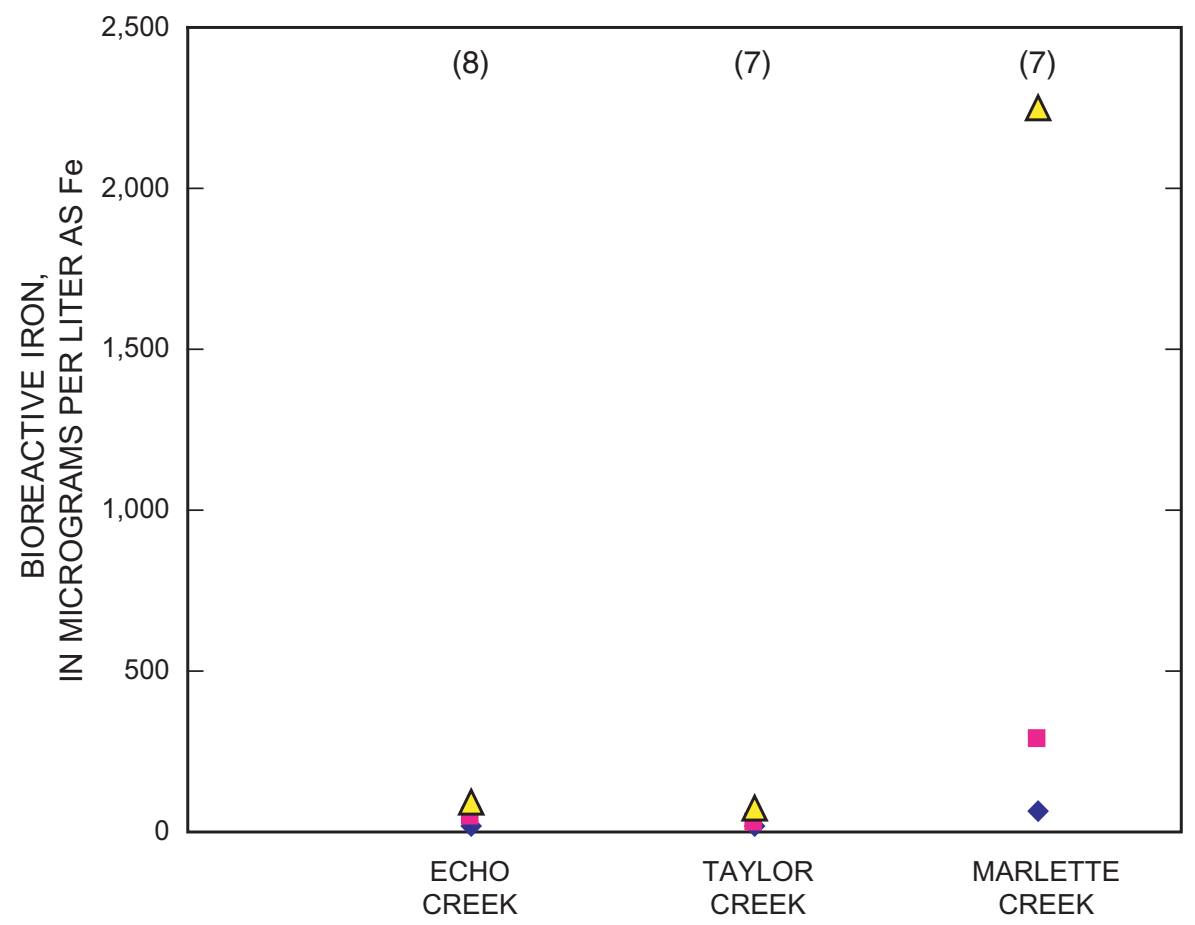

Figure 7. Concentrations of nutrients in samples from Echo, Taylor, and Marlette Creeks: (A) dissolved nitrate (sum of nitrate plus nitrite), (B) dissolved ammonia, (C) total Kjeldahl nitrogen (ammonia plus organic nitrogen), (D) dissolved orthophosphorus (soluble reactive phosphorus), (E) total phosphorus, and ( $P$ ) total bioreactive iron - Continued. 


\section{APPENDIXES}


30 Nutrients in Upper and Lower Echo, Fallen Leaf, Spooner, and Marlette Lakes and Associated Streams, CA and NV, 2002-03 
Appendix A. Physical and chemical profile data collected from study area lakes, 2002-03

[Abbreviations: $\mathrm{m}$, meters; ${ }^{\circ} \mathrm{C}$, degrees Celsius; $\mu \mathrm{S} / \mathrm{cm}$, microsiemens per centimeter; $\mathrm{mg} / \mathrm{L}$, milligrams per liter; std, standard; NTU, nephelometric turbidity units]

\begin{tabular}{|c|c|c|c|c|c|c|c|c|}
\hline $\begin{array}{l}\text { Site no. } \\
\text { (see } \\
\text { fig. 2) }\end{array}$ & Station name & $\begin{array}{c}\text { Date } \\
\text { (yyyymmdd) }\end{array}$ & Time & $\begin{array}{l}\text { Depth } \\
(\mathrm{m})\end{array}$ & $\begin{array}{l}\text { Water } \\
\text { temp- } \\
\text { erature } \\
\left({ }^{\circ} \mathrm{C}\right)\end{array}$ & $\begin{array}{l}\text { Specific } \\
\text { cond- } \\
\text { uctance } \\
(\mu \mathrm{S} / \mathrm{cm} \\
\left.\text { at } 25^{\circ} \mathrm{C}\right)\end{array}$ & $\begin{array}{l}\text { Dis- } \\
\text { solved } \\
\text { oxygen } \quad \mathrm{pH} \\
\text { (mg/L) (std. units) }\end{array}$ & $\begin{array}{l}\text { Turb- } \\
\text { idity } \\
\text { (NTU) }\end{array}$ \\
\hline \multirow[t]{12}{*}{1} & Lower Echo Lake, east & 20020822 & 1225 & 0.1 & 17.6 & 6.5 & 7.3 & \\
\hline & & & 1226 & 1.0 & 17.6 & 6.5 & 7.2 & \\
\hline & & & 1228 & 2.0 & 17.6 & 6.5 & 7.1 & \\
\hline & & & 1229 & 4.0 & 17.5 & 6.5 & 7.1 & \\
\hline & & & 1230 & 6.0 & 17.1 & 6.5 & 7.1 & \\
\hline & & & 1231 & 8.0 & 17.0 & 6.5 & 7.1 & \\
\hline & & & 1232 & 10.0 & 16.9 & 6.5 & 7.1 & \\
\hline & & & 1233 & 11.0 & 16.2 & 6.5 & 7.5 & \\
\hline & & & 1234 & 12.0 & 11.3 & 6.5 & 9.9 & \\
\hline & & & 1235 & 13.0 & 9.1 & 6.5 & 10.3 & \\
\hline & & & 1236 & 14.0 & 8.3 & 6.6 & 10.3 & \\
\hline & & & 1237 & 14.5 & 8.5 & 6.8 & 10.2 & \\
\hline \multirow[t]{28}{*}{2} & Lower Echo Lake near center & 20020529 & 1257 & 0.2 & 10.8 & 6.3 & 8.7 & \\
\hline & & & 1258 & 1.0 & 8.3 & 6.1 & 8.9 & \\
\hline & & & 1259 & 2.0 & 8.0 & 6.0 & 8.9 & \\
\hline & & & 1301 & 3.0 & 7.4 & 5.9 & 8.8 & \\
\hline & & & 1303 & 4.0 & 7.2 & 5.9 & 8.6 & \\
\hline & & & 1304 & 5.0 & 6.7 & 5.9 & 8.6 & \\
\hline & & & 1306 & 6.0 & 6.6 & 5.9 & 8.5 & \\
\hline & & & 1308 & 7.0 & 6.4 & 5.8 & 8.6 & \\
\hline & & & 1309 & 8.0 & 6.1 & 5.9 & 8.6 & \\
\hline & & & 1310 & 9.0 & 6.0 & 5.9 & 8.6 & \\
\hline & & & 1312 & 10.0 & 5.8 & 6.1 & 8.5 & \\
\hline & & & 1313 & 11.0 & 5.8 & 6.0 & 8.4 & \\
\hline & & & 1314 & 12.0 & 5.7 & 6.0 & 8.4 & \\
\hline & & & 1315 & 13.0 & 5.6 & 6.1 & 8.4 & \\
\hline & & & 1317 & 14.0 & 5.6 & 6.1 & 8.3 & \\
\hline & & & 1318 & 15.0 & 5.6 & 6.1 & 8.3 & \\
\hline & & & 1320 & 15.9 & 5.5 & 6.1 & 8.3 & \\
\hline & & 20020822 & 0850 & 0.1 & 17.1 & 6.7 & 7.0 & \\
\hline & & & 0852 & 1.0 & 17.1 & 6.7 & 7.0 & \\
\hline & & & 0853 & 3.0 & 17.1 & 6.7 & 7.0 & \\
\hline & & & 0854 & 5.0 & 17.0 & 6.7 & 7.0 & \\
\hline & & & 0855 & 7.0 & 17.0 & 6.7 & 7.0 & \\
\hline & & & 0857 & 9.0 & 16.9 & 6.7 & 7.0 & \\
\hline & & & 0859 & 10.0 & 16.7 & 6.6 & 7.0 & \\
\hline & & & 0900 & 11.0 & 13.8 & 6.6 & 8.6 & \\
\hline & & & 0901 & 12.0 & 10.5 & 6.7 & 9.7 & \\
\hline & & & 0902 & 13.0 & 9.1 & 6.7 & 9.7 & \\
\hline & & & 0903 & 13.7 & 8.6 & 6.7 & 9.4 & \\
\hline
\end{tabular}


Appendix A. Physical and chemical profile data collected from study area lakes, 2002-03-Continued

[Abbreviations: $\mathrm{m}$, meters; ${ }^{\circ} \mathrm{C}$, degrees Celsius; $\mu \mathrm{S} / \mathrm{cm}$, microsiemens per centimeter; $\mathrm{mg} / \mathrm{L}$, milligrams per liter; std, standard; NTU, nephelometric turbidity units]

\begin{tabular}{|c|c|c|c|c|c|c|c|c|c|}
\hline $\begin{array}{l}\text { Site no. } \\
\text { (see } \\
\text { fig. 2) }\end{array}$ & Station name & $\begin{array}{c}\text { Date } \\
\text { (yyyymmdd) }\end{array}$ & Time & $\begin{array}{l}\text { Depth } \\
(\mathrm{m})\end{array}$ & $\begin{array}{c}\text { Water } \\
\text { temp- } \\
\text { erature } \\
\left({ }^{\circ} \mathrm{C}\right)\end{array}$ & $\begin{array}{l}\text { Specific } \\
\text { cond- } \\
\text { uctance } \\
(\mu \mathrm{S} / \mathrm{cm} \\
\left.\text { at } 25^{\circ} \mathrm{C}\right)\end{array}$ & $\begin{array}{c}\text { Dis- } \\
\text { solved } \\
\text { oxygen } \\
(\mathrm{mg} / \mathrm{L})\end{array}$ & $\begin{array}{c}\mathrm{pH} \\
\text { (std. units) }\end{array}$ & $\begin{array}{l}\text { Turb- } \\
\text { idity } \\
\text { (NTU) }\end{array}$ \\
\hline \multirow[t]{40}{*}{2} & Lower Echo Lake near center & r 20021030 & 0926 & 0.2 & 9.7 & 7.4 & 7.8 & & \\
\hline & & & 0928 & 1.0 & 9.7 & 7.4 & 7.8 & 6.6 & 0.47 \\
\hline & & & 0929 & 3.0 & 9.7 & 7.4 & 7.7 & & \\
\hline & & & 0930 & 5.0 & 9.7 & 7.3 & 7.9 & & \\
\hline & & & 0931 & 7.0 & 9.7 & 7.3 & 7.7 & & \\
\hline & & & 0932 & 9.0 & 9.7 & 7.2 & 7.7 & 7.0 & 0.21 \\
\hline & & & 0933 & 11.0 & 9.7 & 7.2 & 7.6 & & \\
\hline & & & 0934 & 13.0 & 9.7 & 7.1 & 7.6 & & \\
\hline & & & 0935 & 15.0 & 9.7 & 7.0 & 7.8 & & \\
\hline & & & 0936 & 16.0 & 9.7 & 7.0 & 7.6 & & \\
\hline & & 20030617 & 0956 & 0.1 & 15.2 & 6.9 & 8.6 & & \\
\hline & & & 0957 & 1.0 & 14.5 & 6.9 & 8.6 & 7.6 & 0.43 \\
\hline & & & 0958 & 2.0 & 13.6 & 6.7 & 8.9 & & \\
\hline & & & 1000 & 3.0 & 12.9 & 6.6 & 8.9 & & \\
\hline & & & 1001 & 4.0 & 12.6 & 6.6 & 8.9 & & \\
\hline & & & 1002 & 5.0 & 10.9 & 6.7 & 9.2 & & \\
\hline & & & 1004 & 6.0 & 9.2 & 6.9 & 9.5 & & \\
\hline & & & 1005 & 7.0 & 7.9 & 6.9 & 9.6 & & \\
\hline & & & 1007 & 8.0 & 6.9 & 7.0 & 9.8 & 7.6 & 0.41 \\
\hline & & & 1009 & 9.0 & 6.1 & 7.0 & 9.9 & & \\
\hline & & & 1010 & 10.0 & 5.2 & 6.9 & 9.8 & & \\
\hline & & & 1012 & 13.0 & 5.0 & 6.9 & 9.6 & & \\
\hline & & & 1013 & 15.5 & 4.5 & 7.1 & 9.3 & & \\
\hline & & 20030819 & 0948 & 0.1 & 18.0 & 6.8 & 8.9 & 10.2 & \\
\hline & & & 0949 & 1.0 & 18.0 & 6.3 & 9.0 & 9.3 & 0.40 \\
\hline & & & 0950 & 2.0 & 17.9 & 6.4 & 8.6 & 8.9 & \\
\hline & & & 0951 & 3.0 & 17.7 & 6.2 & 8.6 & 8.6 & \\
\hline & & & 0952 & 4.0 & 17.3 & 6.2 & 8.6 & 8.4 & \\
\hline & & & 0954 & 5.0 & 17.0 & 6.2 & 8.4 & 8.1 & \\
\hline & & & 0955 & 6.0 & 16.8 & 6.2 & 8.4 & 7.8 & \\
\hline & & & 0955 & 7.0 & 16.6 & 6.2 & 8.4 & 7.6 & \\
\hline & & & 0956 & 8.0 & 16.2 & 6.2 & 8.4 & 7.4 & \\
\hline & & & 0957 & 9.0 & 15.5 & 6.2 & 8.5 & 7.3 & \\
\hline & & & 0958 & 10.0 & 14.0 & 6.2 & 9.2 & 7.2 & \\
\hline & & & 0959 & 11.0 & 11.6 & 6.4 & 9.9 & 7.1 & \\
\hline & & & 1000 & 12.0 & 8.3 & 6.5 & 10.5 & 7.0 & 0.47 \\
\hline & & & 1001 & 13.0 & 7.0 & 6.5 & 10.3 & 7.0 & \\
\hline & & & 1002 & 14.0 & 6.5 & 6.6 & 10.0 & 6.9 & \\
\hline & & & 1003 & 15.0 & 6.2 & 6.8 & 9.8 & 6.9 & \\
\hline & & & 1004 & 15.4 & 6.1 & 6.8 & 9.9 & 6.9 & \\
\hline
\end{tabular}


Appendix A. Physical and chemical profile data collected from study area lakes, 2002-03-Continued

[Abbreviations: $\mathrm{m}$, meters; ${ }^{\circ} \mathrm{C}$, degrees Celsius; $\mu \mathrm{S} / \mathrm{cm}$, microsiemens per centimeter; $\mathrm{mg} / \mathrm{L}$, milligrams per liter; std, standard; NTU, nephelometric turbidity units]

\begin{tabular}{|c|c|c|c|c|c|c|c|c|c|}
\hline $\begin{array}{l}\text { Site no. } \\
\text { (see } \\
\text { fig. 2) }\end{array}$ & Station name & $\begin{array}{c}\text { Date } \\
\text { (yyyymmdd) }\end{array}$ & Time & $\begin{array}{l}\text { Depth } \\
(\mathrm{m})\end{array}$ & $\begin{array}{l}\text { Water } \\
\text { temp- } \\
\text { erature } \\
\left({ }^{\circ} \mathrm{C}\right)\end{array}$ & $\begin{array}{l}\text { Specific } \\
\text { cond- } \\
\text { uctance } \\
(\mu \mathrm{S} / \mathrm{cm} \\
\left.\text { at } 25^{\circ} \mathrm{C}\right)\end{array}$ & $\begin{array}{c}\text { Dis- } \\
\text { solved } \\
\text { oxygen } \\
(\mathrm{mg} / \mathrm{L})\end{array}$ & $\begin{array}{c}\mathrm{pH} \\
\text { (std. units) }\end{array}$ & $\begin{array}{l}\text { Turb- } \\
\text { idity } \\
\text { (NTU) }\end{array}$ \\
\hline \multirow[t]{11}{*}{2} & Lower Echo Lake near center & 20031020 & 0900 & 0.1 & 11.4 & 6.8 & 10.3 & 9.5 & \\
\hline & & & 0901 & 1.0 & 11.4 & 6.8 & 9.8 & 9.0 & 0.50 \\
\hline & & & 0902 & 2.0 & 11.4 & 6.8 & 9.5 & 8.6 & \\
\hline & & & 0903 & 4.0 & 11.4 & 6.7 & 8.8 & 8.4 & \\
\hline & & & 0904 & 6.0 & 11.4 & 6.7 & 8.5 & 8.1 & \\
\hline & & & 0905 & 8.0 & 11.3 & 6.6 & 8.5 & 7.9 & \\
\hline & & & 0907 & 10.0 & 11.3 & 6.6 & 8.3 & 7.7 & \\
\hline & & & 0908 & 12.0 & 11.2 & 6.6 & 8.2 & 7.4 & \\
\hline & & & 0909 & 14.0 & 11.0 & 6.6 & 8.0 & 7.2 & \\
\hline & & & 0910 & 16.0 & 8.4 & 6.8 & 7.7 & 6.9 & 0.40 \\
\hline & & & 0911 & 17.5 & 7.0 & 7.0 & 7.7 & 6.9 & \\
\hline \multirow[t]{6}{*}{3} & Lower Echo Lake, southwest & 20020822 & 0956 & 0.1 & 17.0 & 6.8 & 7.3 & & \\
\hline & & & 0957 & 1.0 & 17.0 & 6.8 & 7.1 & & \\
\hline & & & 0958 & 2.0 & 16.9 & 6.8 & 7.1 & & \\
\hline & & & 0959 & 3.0 & 16.7 & 6.8 & 7.1 & & \\
\hline & & & 1000 & 4.0 & 16.7 & 6.8 & 7.1 & & \\
\hline & & & 1001 & 4.3 & 16.7 & 6.8 & 7.1 & & \\
\hline \multirow[t]{21}{*}{4} & Lower Echo Lake, northwest & 20020822 & 1102 & 0.1 & 17.4 & 6.8 & 7.2 & & \\
\hline & & & 1103 & 1.0 & 17.2 & 6.8 & 7.1 & & \\
\hline & & & 1104 & 2.0 & 17.1 & 6.8 & 7.1 & & \\
\hline & & & 1106 & 3.0 & 17.1 & 6.7 & 7.1 & & \\
\hline & & & 1108 & 4.0 & 17.0 & 6.7 & 7.1 & & \\
\hline & & & 1109 & 5.0 & 17.0 & 6.7 & 7.1 & & \\
\hline & & & 1111 & 6.0 & 17.0 & 6.6 & 7.1 & & \\
\hline & & & 1112 & 7.0 & 17.0 & 6.6 & 7.1 & & \\
\hline & & & 1114 & 8.0 & 17.0 & 6.6 & 7.1 & & \\
\hline & & & 1115 & 9.0 & 16.9 & 6.6 & 7.1 & & \\
\hline & & & 1116 & 10.0 & 16.7 & 6.6 & 7.1 & & \\
\hline & & & 1117 & 11.0 & 12.5 & 6.6 & 9.2 & & \\
\hline & & & 1118 & 12.0 & 10.0 & 6.6 & 9.6 & & \\
\hline & & & 1119 & 13.0 & 9.4 & 6.6 & 9.8 & & \\
\hline & & & 1120 & 14.0 & 8.3 & 6.7 & 9.6 & & \\
\hline & & & 1129 & 15.0 & 8.0 & 6.8 & 9.6 & & \\
\hline & & & 1131 & 16.0 & 7.5 & 6.9 & 8.9 & & \\
\hline & & & 1132 & 17.0 & 7.4 & 6.9 & 8.8 & & \\
\hline & & & 1133 & 18.0 & 7.2 & 6.9 & 8.4 & & \\
\hline & & & 1135 & 19.0 & 7.2 & 7.0 & 8.2 & & \\
\hline & & & 1136 & 19.5 & 7.2 & 7.0 & 8.2 & & \\
\hline
\end{tabular}


Appendix A. Physical and chemical profile data collected from study area lakes, 2002-03—Continued

[Abbreviations: $\mathrm{m}$, meters; ${ }^{\circ} \mathrm{C}$, degrees Celsius; $\mu \mathrm{S} / \mathrm{cm}$, microsiemens per centimeter; mg/L, milligrams per liter; std, standard; NTU, nephelometric turbidity units]

\begin{tabular}{|c|c|c|c|c|c|c|c|c|c|}
\hline $\begin{array}{l}\text { Site no. } \\
\text { (see } \\
\text { fig. 2) }\end{array}$ & Station name & $\begin{array}{c}\text { Date } \\
\text { (yyyymmdd) }\end{array}$ & Time & Depth & $\begin{array}{l}\text { Water } \\
\text { temp- } \\
\text { erature } \\
\left.\quad{ }^{\circ} \mathrm{C}\right)\end{array}$ & $\begin{array}{l}\text { Specific } \\
\text { cond- } \\
\text { uctance } \\
(\mu S / \mathrm{cm} \\
\left.\text { at } 25^{\circ} \mathrm{C}\right)\end{array}$ & $\begin{array}{c}\text { Dis- } \\
\text { solved } \\
\text { oxygen } \\
\text { (mg/L) }\end{array}$ & $\begin{array}{c}\mathrm{pH} \\
\text { (std. units) }\end{array}$ & $\begin{array}{l}\text { Turb- } \\
\text { idity } \\
\text { (NTU) }\end{array}$ \\
\hline \multirow{38}{*}{5} & Upper Echo Lake near center & 20020530 & 1110 & 0.2 & 9.0 & 5.7 & 8.4 & & \\
\hline & & & 1111 & 1.0 & 6.4 & 5.4 & 8.7 & & \\
\hline & & & 1112 & 2.0 & 6.1 & 5.3 & 8.7 & & \\
\hline & & & 1113 & 3.0 & 5.7 & 5.1 & 8.8 & & \\
\hline & & & 1114 & 4.0 & 5.2 & 5.0 & 8.8 & & \\
\hline & & & 1115 & 5.0 & 5.0 & 5.1 & 8.8 & & \\
\hline & & & 1116 & 6.0 & 5.0 & 5.1 & 8.8 & & \\
\hline & & & 1117 & 6.7 & 5.0 & 5.2 & 8.8 & & \\
\hline & & & 1119 & 0.2 & 9.0 & 5.7 & 8.4 & & \\
\hline & & 20020826 & 1104 & 0.1 & 17.6 & 5.1 & 6.8 & & \\
\hline & & & 1106 & 1.0 & 17.6 & 5.1 & 6.8 & & \\
\hline & & & 1107 & 2.0 & 17.5 & 5.1 & 6.8 & & \\
\hline & & & 1109 & 3.0 & 17.4 & 5.1 & 6.8 & & \\
\hline & & & 1110 & 4.0 & 17.3 & 5.1 & 6.8 & & \\
\hline & & & 1112 & 5.0 & 17.2 & 5.1 & 6.8 & & \\
\hline & & & 1113 & 6.0 & 17.0 & 5.2 & 6.8 & & \\
\hline & & & 1115 & 7.0 & 17.0 & 5.1 & 6.8 & & \\
\hline & & & 1116 & 8.0 & 16.0 & 5.1 & 7.0 & & \\
\hline & & & 1117 & 9.0 & 12.3 & 5.0 & 8.3 & & \\
\hline & & & 1118 & 10.0 & 10.0 & 4.9 & 8.6 & & \\
\hline & & & 1119 & 11.0 & 8.9 & 4.9 & 9.0 & & \\
\hline & & & 1121 & 12.0 & 8.1 & 5.1 & 8.9 & & \\
\hline & & 20030617 & 1131 & 0.1 & 14.4 & 5.3 & 8.7 & & \\
\hline & & & 1133 & 1.0 & 11.4 & 5.2 & 9.0 & 8.9 & 0.21 \\
\hline & & & 1134 & 2.0 & 9.6 & 5.0 & 9.2 & & \\
\hline & & & 1136 & 3.0 & 8.6 & 5.1 & 9.6 & & \\
\hline & & & 1137 & 4.0 & 7.6 & 5.1 & 10.1 & 8.9 & 0.48 \\
\hline & & & 1140 & 5.0 & 7.0 & 5.1 & 10.1 & & \\
\hline & & & 1141 & 6.0 & 6.8 & 5.1 & 10.2 & & \\
\hline & & & 1142 & 6.1 & 6.7 & 5.1 & 10.2 & & \\
\hline & & 20030819 & 1047 & 0.1 & 18.7 & 5.1 & 8.7 & 7.1 & \\
\hline & & & 1048 & 1.0 & 18.5 & 4.9 & 8.7 & 7.1 & 0.45 \\
\hline & & & 1049 & 2.0 & 18.2 & 5.0 & 8.2 & 7.0 & \\
\hline & & & 1050 & 3.0 & 18.1 & 5.0 & 8.2 & 7.0 & \\
\hline & & & 1051 & 4.0 & 17.4 & 5.0 & 8.1 & 6.9 & \\
\hline & & & 1052 & 5.0 & 16.9 & 5.0 & 8.1 & 6.9 & \\
\hline & & & 1053 & 6.0 & 16.6 & 5.0 & 7.8 & 6.9 & 0.48 \\
\hline & & & 1055 & 6.5 & 16.4 & 5.0 & 7.0 & 6.9 & \\
\hline
\end{tabular}


Appendix A. Physical and chemical profile data collected from study area lakes, 2002-03-Continued

[Abbreviations: $\mathrm{m}$, meters; ${ }^{\circ} \mathrm{C}$, degrees Celsius; $\mu \mathrm{S} / \mathrm{cm}$, microsiemens per centimeter; $\mathrm{mg} / \mathrm{L}$, milligrams per liter; std, standard; NTU, nephelometric turbidity units]

\begin{tabular}{|c|c|c|c|c|c|c|c|c|}
\hline $\begin{array}{c}\text { Site no. } \\
\text { (see } \\
\text { fig. 2) }\end{array}$ & Station name & $\begin{array}{c}\text { Date } \\
\text { (yyyymmdd) }\end{array}$ & Time & $(\mathrm{m})$ & $\begin{array}{l}\text { Water } \\
\text { temp- } \\
\text { erature }\end{array}$ & $\begin{array}{l}\text { Specific } \\
\text { cond- } \\
\text { uctance } \\
(\mu \mathrm{S} / \mathrm{cm} \\
\left.\text { at } 25^{\circ} \mathrm{C}\right)\end{array}$ & $\begin{array}{l}\text { Dis- } \\
\text { solved } \\
\text { oxygen } \quad \mathrm{pH} \\
\text { (mg/L) (std. units) }\end{array}$ & $\begin{array}{l}\text { Turb- } \\
\text { idity } \\
\text { (NTU) }\end{array}$ \\
\hline \multirow[t]{17}{*}{6} & Upper Echo Lake, east & 20020826 & 0930 & 0.1 & 17.4 & 5.3 & 6.9 & \\
\hline & & & 0932 & 1.0 & 17.4 & 5.3 & 6.9 & \\
\hline & & & 0934 & 3.0 & 17.4 & 5.3 & 6.9 & \\
\hline & & & 0935 & 5.0 & 17.3 & 5.3 & 6.8 & \\
\hline & & & 0939 & 7.0 & 17.2 & 5.3 & 6.7 & \\
\hline & & & 0942 & 8.0 & 16.2 & 5.2 & 7.0 & \\
\hline & & & 0944 & 9.0 & 11.3 & 5.1 & 9.8 & \\
\hline & & & 0945 & 10.0 & 9.2 & 5.0 & 9.9 & \\
\hline & & & 0947 & 11.0 & 7.6 & 5.1 & 9.9 & \\
\hline & & & 0949 & 12.0 & 6.8 & 5.2 & 9.7 & \\
\hline & & & 0950 & 13.0 & 6.2 & 5.4 & 9.5 & \\
\hline & & & 0953 & 14.0 & 5.9 & 5.5 & 8.7 & \\
\hline & & & 0954 & 16.0 & 5.4 & 6.0 & 7.1 & \\
\hline & & & 0956 & 18.0 & 5.2 & 6.5 & 5.7 & \\
\hline & & & 0957 & 20.0 & 5.0 & 7.0 & 4.5 & \\
\hline & & & 0959 & 22.0 & 5.0 & 7.9 & 2.8 & \\
\hline & & & 1001 & 23.6 & 5.0 & 8.1 & 2.6 & \\
\hline \multirow[t]{11}{*}{7} & Upper Echo Lake, southwest & 20020826 & 1225 & 0.1 & 17.7 & 5.1 & 7.0 & \\
\hline & & & 1227 & 1.0 & 17.4 & 5.1 & 6.9 & \\
\hline & & & 1229 & 2.0 & 17.1 & 5.1 & 6.9 & \\
\hline & & & 1231 & 3.0 & 17.1 & 5.1 & 6.9 & \\
\hline & & & 1232 & 4.0 & 17.0 & 5.1 & 6.9 & \\
\hline & & & 1233 & 5.0 & 17.0 & 5.1 & 6.8 & \\
\hline & & & 1234 & 6.0 & 16.8 & 5.1 & 6.8 & \\
\hline & & & 1236 & 7.0 & 16.8 & 5.1 & 6.8 & \\
\hline & & & 1238 & 8.0 & 13.0 & 4.8 & 9.0 & \\
\hline & & & 1239 & 9.0 & 10.3 & 4.9 & 8.8 & \\
\hline & & & 1240 & 9.6 & 9.7 & 4.9 & 8.6 & \\
\hline \multirow[t]{4}{*}{8} & Upper Echo Lake near inlet & 20020826 & 1322 & 0.1 & 18.2 & 5.1 & 7.0 & \\
\hline & & & 1324 & 0.5 & 18.2 & 5.1 & 7.0 & \\
\hline & & & 1325 & 1.0 & 18.1 & 5.1 & 7.1 & \\
\hline & & & 1326 & 1.2 & 18.0 & 5.1 & 7.0 & \\
\hline
\end{tabular}


Appendix A. Physical and chemical profile data collected from study area lakes, 2002-03 — Continued

[Abbreviations: $\mathrm{m}$, meters; ${ }^{\circ} \mathrm{C}$, degrees Celsius; $\mu \mathrm{S} / \mathrm{cm}$, microsiemens per centimeter; $\mathrm{mg} / \mathrm{L}$, milligrams per liter; std, standard; NTU, nephelometric turbidity units]

\begin{tabular}{|c|c|c|c|c|c|c|c|c|}
\hline $\begin{array}{c}\text { Site no. } \\
\text { (see } \\
\text { fig. 2) }\end{array}$ & Station name & $\begin{array}{c}\text { Date } \\
\text { (yyyymmdd) }\end{array}$ & Time & Depth & $\begin{array}{l}\text { Water } \\
\text { temp- } \\
\text { erature } \\
\left({ }^{\circ} \mathrm{C}\right)\end{array}$ & $\begin{array}{l}\text { Specific } \\
\text { cond- } \\
\text { uctance } \\
(\mu S / \mathrm{cm} \\
\left.\text { at } 25^{\circ} \mathrm{C}\right)\end{array}$ & $\begin{array}{l}\text { Dis- } \\
\text { solved } \\
\text { oxygen } \quad \mathrm{pH} \\
\text { (mg/L) (std. units) }\end{array}$ & $\begin{array}{l}\text { Turb- } \\
\text { idity } \\
\text { (NTU) }\end{array}$ \\
\hline \multirow[t]{13}{*}{9} & Fallen Leaf Lake, north & 20020814 & 1240 & 0.1 & 21.5 & 20.0 & 9.4 & \\
\hline & & & 1243 & 1.0 & 20.2 & 19.8 & 9.6 & \\
\hline & & & 1245 & 5.0 & 18.9 & 19.6 & 9.8 & \\
\hline & & & 1247 & 10.0 & 18.3 & 19.5 & 9.9 & \\
\hline & & & 1249 & 12.0 & 17.6 & 19.5 & 10.3 & \\
\hline & & & 1251 & 14.0 & 14.0 & 19.3 & 12.6 & \\
\hline & & & 1253 & 16.0 & 11.1 & 19.2 & 13.1 & \\
\hline & & & 1255 & 18.0 & 9.5 & 19.2 & 13.2 & \\
\hline & & & 1257 & 20.0 & 8.2 & 19.2 & 13.2 & \\
\hline & & & 1300 & 22.0 & 7.6 & 19.3 & 13.2 & \\
\hline & & & 1302 & 25.0 & 6.9 & 19.3 & 13.1 & \\
\hline & & & 1304 & 30.0 & 6.2 & 19.3 & 12.9 & \\
\hline & & & 1306 & 34.0 & 5.7 & 19.4 & 12.9 & \\
\hline \multirow[t]{23}{*}{10} & Fallen Leaf Lake near center & 20020603 & 1031 & 0.1 & 12.4 & 18.7 & 8.1 & \\
\hline & & & 1032 & 1.0 & 12.1 & 18.6 & 8.8 & \\
\hline & & & 1033 & 2.0 & 11.8 & 18.6 & 8.7 & \\
\hline & & & 1034 & 3.0 & 11.7 & 18.5 & 8.6 & \\
\hline & & & 1034 & 4.0 & 11.5 & 18.5 & 8.5 & \\
\hline & & & 1035 & 5.0 & 11.4 & 18.5 & 8.5 & \\
\hline & & & 1036 & 6.0 & 11.3 & 18.5 & 8.6 & \\
\hline & & & 1036 & 7.0 & 10.8 & 18.4 & 8.6 & \\
\hline & & & 1037 & 8.0 & 10.6 & 18.5 & 8.9 & \\
\hline & & & 1038 & 9.0 & 10.4 & 18.7 & 8.8 & \\
\hline & & & 1039 & 10.0 & 10.3 & 18.7 & 8.8 & \\
\hline & & & 1040 & 11.0 & 9.8 & 18.8 & 8.9 & \\
\hline & & & 1041 & 12.0 & 9.6 & 18.8 & 9.0 & \\
\hline & & & 1042 & 13.0 & 9.4 & 18.8 & 8.9 & \\
\hline & & & 1043 & 14.0 & 9.2 & 18.8 & 8.9 & \\
\hline & & & 1044 & 15.0 & 8.9 & 19.0 & 8.9 & \\
\hline & & & 1045 & 16.0 & 8.7 & 19.0 & 8.9 & \\
\hline & & & 1047 & 17.0 & 8.5 & 18.9 & 8.8 & \\
\hline & & & 1048 & 18.0 & 8.3 & 18.8 & 8.9 & \\
\hline & & & 1056 & 19.0 & 7.7 & 18.7 & 8.9 & \\
\hline & & & 1057 & 20.0 & 7.5 & 18.7 & 8.9 & \\
\hline & & & 1058 & 21.0 & 7.4 & 18.7 & 8.5 & \\
\hline & & & 1059 & 22.0 & 7.3 & 18.6 & 8.3 & \\
\hline
\end{tabular}


Appendix A. Physical and chemical profile data collected from study area lakes, 2002-03-Continued

[Abbreviations: $\mathrm{m}$, meters; ${ }^{\circ} \mathrm{C}$, degrees Celsius; $\mu \mathrm{S} / \mathrm{cm}$, microsiemens per centimeter; $\mathrm{mg} / \mathrm{L}$, milligrams per liter; std, standard; NTU, nephelometric turbidity units]

\begin{tabular}{|c|c|c|c|c|c|c|c|c|c|}
\hline $\begin{array}{l}\text { Site no. } \\
\text { (see } \\
\text { fig. 2) }\end{array}$ & Station name & $\begin{array}{c}\text { Date } \\
\text { (yyyymmdd) }\end{array}$ & Time & $\begin{array}{l}\text { Depth } \\
\text { (m) }\end{array}$ & $\begin{array}{c}\text { Water } \\
\text { temp- } \\
\text { erature } \\
\left({ }^{\circ} \mathrm{C}\right)\end{array}$ & $\begin{array}{l}\text { Specific } \\
\text { cond- } \\
\text { uctance } \\
(\mu \mathrm{S} / \mathrm{cm} \\
\left.\text { at } 25^{\circ} \mathrm{C}\right)\end{array}$ & $\begin{array}{c}\text { Dis- } \\
\text { solved } \\
\text { oxygen } \\
\text { (mg/L) }\end{array}$ & $\begin{array}{c}\mathrm{pH} \\
\text { (std. units) }\end{array}$ & $\begin{array}{l}\text { Turb- } \\
\text { idity } \\
\text { (NTU) }\end{array}$ \\
\hline \multirow[t]{40}{*}{10} & Fallen Leaf Lake near center & 20020814 & 1111 & 0.1 & 20.2 & 20.6 & 10.5 & & \\
\hline & & & 1128 & 1.0 & 19.6 & 20.5 & 10.2 & & \\
\hline & & & 1129 & 5.0 & 19.0 & 20.1 & 10.3 & & \\
\hline & & & 1131 & 10.0 & 18.3 & 20.6 & 10.4 & & \\
\hline & & & 1133 & 12.0 & 17.0 & 20.1 & 11.1 & & \\
\hline & & & 1135 & 14.0 & 12.7 & 19.7 & 13.4 & & \\
\hline & & & 1137 & 16.0 & 10.4 & 19.6 & 13.8 & & \\
\hline & & & 1138 & 18.0 & 9.4 & 19.7 & 13.8 & & \\
\hline & & & 1140 & 20.0 & 8.9 & 19.6 & 13.8 & & \\
\hline & & & 1142 & 25.0 & 7.7 & 19.6 & 13.8 & & \\
\hline & & & 1144 & 30.0 & 6.8 & 19.7 & 13.6 & & \\
\hline & & & 1146 & 35.0 & 5.9 & 19.6 & 13.3 & & \\
\hline & & & 1148 & 40.0 & 5.5 & 19.6 & 13.2 & & \\
\hline & & & 1150 & 45.0 & 5.0 & 19.7 & 13.0 & & \\
\hline & & & 1152 & 50.0 & 4.8 & 19.6 & 12.9 & & \\
\hline & & & 1154 & 55.0 & 4.6 & 19.7 & 12.8 & & \\
\hline & & & 1155 & 60.0 & 4.6 & 19.6 & 12.8 & & \\
\hline & & & 1157 & 65.0 & 4.5 & 19.7 & 12.7 & & \\
\hline & & & 1159 & 68.0 & 4.5 & 19.6 & 12.7 & & \\
\hline & & 20021028 & 1112 & 0.2 & 12.5 & 22.2 & 8.1 & & \\
\hline & & & 1113 & 1.0 & 12.5 & 22.1 & 8.1 & 7.9 & 0.18 \\
\hline & & & 1114 & 3.0 & 12.4 & 22.0 & 8.0 & & \\
\hline & & & 1115 & 5.0 & 12.4 & 21.9 & 8.0 & & \\
\hline & & & 1116 & 7.0 & 12.4 & 21.8 & 8.0 & & \\
\hline & & & 1117 & 9.0 & 12.4 & 21.8 & 8.0 & & \\
\hline & & & 1118 & 11.0 & 12.4 & 21.6 & 8.0 & & \\
\hline & & & 1119 & 13.0 & 12.4 & 21.5 & 8.0 & & \\
\hline & & & 1119 & 15.0 & 12.4 & 21.4 & 8.0 & & \\
\hline & & & 1121 & 18.0 & 12.4 & 21.1 & 8.0 & & \\
\hline & & & 1122 & 20.0 & 12.4 & 21.0 & 8.0 & & \\
\hline & & & 1124 & 21.0 & 12.4 & 20.8 & 8.0 & & \\
\hline & & & 1125 & 23.0 & 8.6 & 20.1 & 9.8 & & \\
\hline & & & 1126 & 26.0 & 7.9 & 20.0 & 9.8 & & \\
\hline & & & 1127 & 30.0 & 6.9 & 20.0 & 9.6 & 7.8 & 0.20 \\
\hline & & & 1128 & 35.0 & 6.0 & 20.2 & 9.2 & & \\
\hline & & & 1129 & 40.0 & 5.5 & 20.1 & 9.1 & & \\
\hline & & & 1131 & 45.0 & 5.2 & 20.1 & 8.9 & & \\
\hline & & & 1132 & 50.0 & 4.9 & 20.0 & 8.8 & & \\
\hline & & & 1132 & 55.0 & 4.8 & 20.1 & 8.7 & & \\
\hline & & & 1133 & 60.3 & 4.6 & 20.1 & 8.6 & & \\
\hline
\end{tabular}


Appendix A. Physical and chemical profile data collected from study area lakes, 2002-03 — Continued

[Abbreviations: $\mathrm{m}$, meters; ${ }^{\circ} \mathrm{C}$, degrees Celsius; $\mu \mathrm{S} / \mathrm{cm}$, microsiemens per centimeter; mg/L, milligrams per liter; std, standard; NTU, nephelometric turbidity units]

\begin{tabular}{|c|c|c|c|c|c|c|c|c|c|}
\hline $\begin{array}{c}\text { Site no. } \\
\text { (see } \\
\text { fig. 2) }\end{array}$ & Station name & $\begin{array}{c}\text { Date } \\
\text { (yyyymmdd) }\end{array}$ & Time & Depth & $\begin{array}{l}\text { Water } \\
\text { temp- } \\
\text { erature } \\
\left.\quad{ }^{\circ} \mathrm{C}\right)\end{array}$ & $\begin{array}{l}\text { Specific } \\
\text { cond- } \\
\text { uctance } \\
(\mu S / \mathrm{cm} \\
\left.\text { at } 25^{\circ} \mathrm{C}\right)\end{array}$ & $\begin{array}{c}\text { Dis- } \\
\text { solved } \\
\text { oxygen } \\
\text { (mg/L) }\end{array}$ & $\begin{array}{c}\mathrm{pH} \\
\text { (std. units) }\end{array}$ & $\begin{array}{l}\text { Turb- } \\
\text { idity } \\
\text { (NTU) }\end{array}$ \\
\hline \multirow[t]{38}{*}{10} & Fallen Leaf Lake near center & 20030529 & 0900 & 0.1 & 12.1 & 21.2 & 8.4 & & \\
\hline & & & 0902 & 1.0 & 11.3 & 20.8 & 8.6 & 7.4 & 0.22 \\
\hline & & & 0903 & 3.0 & 10.8 & 20.6 & 8.5 & & \\
\hline & & & 0904 & 5.0 & 9.8 & 20.4 & 8.7 & & \\
\hline & & & 0906 & 7.0 & 9.0 & 19.9 & 9.1 & & \\
\hline & & & 0907 & 9.0 & 7.9 & 20.3 & 9.8 & & \\
\hline & & & 0909 & 11.0 & 7.5 & 20.3 & 9.0 & & \\
\hline & & & 0910 & 13.0 & 7.2 & 20.3 & 9.0 & & \\
\hline & & & 0911 & 15.0 & 7.0 & 20.3 & 9.0 & & \\
\hline & & & 0913 & 20.0 & 6.1 & 20.3 & 8.9 & 7.6 & 0.29 \\
\hline & & & 0914 & 25.0 & 5.4 & 20.3 & 8.9 & & \\
\hline & & & 0916 & 30.0 & 5.2 & 20.2 & 8.8 & & \\
\hline & & & 0918 & 35.0 & 5.0 & 20.2 & 8.7 & & \\
\hline & & & 0920 & 40.0 & 4.9 & 20.2 & 8.6 & & \\
\hline & & & 0921 & 45.0 & 4.8 & 20.1 & 8.6 & & \\
\hline & & & 0923 & 50.0 & 4.8 & 20.1 & 8.5 & & \\
\hline & & & 0924 & 55.0 & 4.7 & 20.1 & 8.5 & & \\
\hline & & & 0926 & 60.0 & 4.7 & 20.2 & 8.5 & & \\
\hline & & & 0928 & 65.0 & 4.6 & 20.2 & 8.4 & & \\
\hline & & & 0930 & 70.0 & 4.6 & 20.1 & 8.4 & & \\
\hline & & 20030812 & 0850 & 0.1 & 17.4 & 19.0 & 8.5 & 8.0 & \\
\hline & & & 0851 & 1.0 & 17.4 & 19.1 & 8.8 & 7.7 & 0.82 \\
\hline & & & 0853 & 5.0 & 17.4 & 19.1 & 8.9 & 7.7 & \\
\hline & & & 0854 & 10.0 & 17.2 & 19.3 & 8.7 & 7.6 & \\
\hline & & & 0856 & 15.0 & 10.8 & 19.2 & 10.8 & 7.7 & \\
\hline & & & 0857 & 20.0 & 8.1 & 19.3 & 10.6 & 7.7 & \\
\hline & & & 0900 & 25.0 & 7.0 & 19.3 & 10.5 & 7.6 & 0.34 \\
\hline & & & 0859 & 30.0 & 5.8 & 19.4 & 10.2 & 7.6 & \\
\hline & & & 0901 & 40.0 & 5.0 & 19.5 & 9.8 & 7.6 & \\
\hline & & 20031020 & 1135 & 0.1 & 13.8 & 19.5 & 10.0 & 8.9 & \\
\hline & & & 1136 & 1.0 & 13.9 & 19.4 & 9.1 & 8.2 & 0.3 \\
\hline & & & 1137 & 5.0 & 13.8 & 19.4 & 9.4 & 8.0 & \\
\hline & & & 1138 & 10.0 & 13.8 & 19.4 & 9.2 & 7.8 & \\
\hline & & & 1139 & 15.0 & 13.8 & 19.4 & 8.5 & 7.6 & \\
\hline & & & 1140 & 20.0 & 8.9 & 19.3 & 10.4 & 7.6 & \\
\hline & & & 1141 & 25.0 & 6.6 & 19.2 & 10.4 & 7.5 & 0.2 \\
\hline & & & 1142 & 30.0 & 5.5 & 19.2 & 9.8 & 7.4 & \\
\hline & & & 1143 & 35.0 & 5.2 & 19.2 & 9.6 & 7.4 & \\
\hline
\end{tabular}


Appendix A. Physical and chemical profile data collected from study area lakes, 2002-03-Continued

[Abbreviations: $\mathrm{m}$, meters; ${ }^{\circ} \mathrm{C}$, degrees Celsius; $\mu \mathrm{S} / \mathrm{cm}$, microsiemens per centimeter; $\mathrm{mg} / \mathrm{L}$, milligrams per liter; std, standard; NTU, nephelometric turbidity units]

\begin{tabular}{|c|c|c|c|c|c|c|c|c|c|}
\hline $\begin{array}{l}\text { Site no. } \\
\text { (see } \\
\text { fig. 2) }\end{array}$ & Station name & $\begin{array}{c}\text { Date } \\
\text { (yyyymmdd) }\end{array}$ & Time & $\begin{array}{l}\text { Depth } \\
\text { (m) }\end{array}$ & $\begin{array}{l}\text { Water } \\
\text { temp- } \\
\text { erature } \\
\quad\left({ }^{\circ} \mathrm{C}\right)\end{array}$ & $\begin{array}{l}\text { Specific } \\
\text { cond- } \\
\text { uctance } \\
(\mu \mathrm{S} / \mathrm{cm} \\
\left.\text { at } 25^{\circ} \mathrm{C}\right)\end{array}$ & $\begin{array}{c}\text { Dis- } \\
\text { solved } \\
\text { oxygen } \\
(\mathrm{mg} / \mathrm{L})\end{array}$ & $\begin{array}{c}\mathrm{pH} \\
\text { (std. units) }\end{array}$ & $\begin{array}{l}\text { Turb- } \\
\text { idity } \\
\text { (NTU) }\end{array}$ \\
\hline \multirow[t]{21}{*}{11} & Fallen Leaf Lake, south & 20020814 & 0929 & 0.1 & 19.6 & 20.9 & 7.5 & & \\
\hline & & & 0930 & 1.0 & 19.5 & 20.9 & 7.4 & & \\
\hline & & & 0932 & 2.0 & 19.4 & 20.9 & 7.4 & & \\
\hline & & & 0934 & 5.0 & 19.0 & 20.8 & 7.3 & & \\
\hline & & & 0936 & 7.0 & 18.5 & 20.6 & 7.3 & & \\
\hline & & & 0939 & 9.0 & 18.3 & 20.6 & 7.3 & & \\
\hline & & & 0941 & 11.0 & 17.6 & 20.5 & 7.5 & & \\
\hline & & & 0943 & 13.0 & 14.2 & 20.3 & 9.1 & & \\
\hline & & & 0944 & 14.0 & 12.4 & 19.9 & 9.5 & & \\
\hline & & & 0946 & 15.0 & 11.6 & 19.8 & 9.5 & & \\
\hline & & & 0948 & 20.0 & 8.8 & 19.9 & 9.6 & & \\
\hline & & & 0950 & 25.0 & 7.5 & 20.0 & 9.6 & & \\
\hline & & & 0951 & 30.0 & 6.5 & 20.1 & 9.4 & & \\
\hline & & & 0954 & 35.0 & 5.8 & 20.1 & 9.2 & & \\
\hline & & & 0957 & 40.0 & 5.3 & 20.1 & 9.1 & & \\
\hline & & & 0959 & 45.0 & 5.0 & 20.2 & 8.9 & & \\
\hline & & & 1002 & 50.0 & 4.8 & 20.2 & 8.9 & & \\
\hline & & & 1004 & 55.0 & 4.7 & 20.2 & 8.8 & & \\
\hline & & & 1005 & 60.0 & 4.6 & 20.2 & 8.7 & & \\
\hline & & & 1007 & 65.0 & 4.5 & 20.1 & 8.6 & & \\
\hline & & & 1009 & 70.0 & 4.4 & 20.1 & 8.5 & & \\
\hline \multirow[t]{7}{*}{12} & Spooner Lake, south & 20020731 & 1200 & 0.2 & 22.0 & 385 & 8.9 & 10.7 & \\
\hline & & & 1203 & 0.5 & 22.0 & 384 & 8.9 & 10.6 & \\
\hline & & & 1204 & 1.0 & 21.8 & 387 & 9.2 & 10.7 & \\
\hline & & & 1207 & 1.5 & 21.0 & 380 & 8.0 & 10.6 & \\
\hline & & & 1209 & 2.0 & 19.9 & 366 & 3.2 & 10.2 & \\
\hline & & & 1211 & 2.5 & 18.9 & 389 & 0.2 & 9.1 & \\
\hline & & & 1213 & 3.2 & 16.5 & 563 & 0.2 & 8.0 & \\
\hline \multirow[t]{8}{*}{13} & Spooner Lake, east & 20020731 & 1003 & 0.2 & 21.8 & 396 & 8.6 & 10.5 & \\
\hline & & & 1005 & 0.5 & 21.8 & 396 & 8.6 & 10.4 & \\
\hline & & & 1006 & 1.0 & 21.3 & 392 & 7.9 & 10.2 & \\
\hline & & & 1008 & 1.5 & 21.2 & 391 & 6.3 & 10.3 & \\
\hline & & & 1010 & 2.0 & 20.2 & 401 & 0.4 & 8.8 & \\
\hline & & & 1013 & 2.5 & 19.0 & 447 & 0.3 & 8.0 & \\
\hline & & & 1015 & 3.0 & 17.6 & 505 & 0.2 & 7.2 & \\
\hline & & & 1016 & 3.5 & 16.1 & 613 & 0.9 & 6.8 & \\
\hline
\end{tabular}


Appendix A. Physical and chemical profile data collected from study area lakes, 2002-03—Continued

[Abbreviations: $\mathrm{m}$, meters; ${ }^{\circ} \mathrm{C}$, degrees Celsius; $\mu \mathrm{S} / \mathrm{cm}$, microsiemens per centimeter; $\mathrm{mg} / \mathrm{L}$, milligrams per liter; std, standard; NTU, nephelometric turbidity units]

\begin{tabular}{|c|c|c|c|c|c|c|c|c|c|}
\hline $\begin{array}{c}\text { Site no. } \\
\text { (see } \\
\text { fig. 2) }\end{array}$ & Station name & $\begin{array}{c}\text { Date } \\
\text { (yyyymmdd) }\end{array}$ & Time & $\begin{array}{l}\text { Depth } \\
(\mathrm{m})\end{array}$ & $\begin{array}{c}\text { Water } \\
\text { temp- } \\
\text { erature } \\
\quad\left({ }^{\circ} \mathrm{C}\right)\end{array}$ & $\begin{array}{l}\text { Specific } \\
\text { cond- } \\
\text { uctance } \\
(\mu S / \mathrm{cm} \\
\left.\text { at } 25^{\circ} \mathrm{C}\right)\end{array}$ & $\begin{array}{l}\text { Dis- } \\
\text { solved } \\
\text { oxygen }\end{array}$ & (std. units) & $\begin{array}{l}\text { Turb- } \\
\text { idity } \\
\text { (NTU) }\end{array}$ \\
\hline \multirow[t]{42}{*}{14} & Spooner Lake near center & 20020605 & 0925 & 0.2 & 18.2 & 363 & 9.8 & 9.5 & \\
\hline & & & 0927 & 1.0 & 18.1 & 364 & 9.7 & 9.5 & \\
\hline & & & 0928 & 1.5 & 18.1 & 365 & 9.7 & 9.5 & \\
\hline & & & 0929 & 2.0 & 18.0 & 365 & 9.4 & 9.5 & \\
\hline & & & 0931 & 2.3 & 17.9 & 365 & 9.7 & 9.5 & \\
\hline & & & 0932 & 2.6 & 17.2 & 368 & 7.4 & 9.3 & \\
\hline & & & 0937 & 3.0 & 16.0 & 413 & 4.5 & 8.6 & \\
\hline & & & 0938 & 3.5 & 15.0 & 413 & 2.4 & 8.2 & \\
\hline & & & 0939 & 4.0 & 14.1 & 476 & 0.2 & 7.8 & \\
\hline & & 20020731 & 0842 & 0.2 & 20.8 & 379 & 7.6 & 9.8 & \\
\hline & & & 0844 & 1.0 & 20.9 & 379 & 7.6 & 9.7 & \\
\hline & & & 0846 & 1.5 & 20.8 & 379 & 7.7 & 9.6 & \\
\hline & & & 0848 & 2.0 & 20.8 & 379 & 7.5 & 9.5 & \\
\hline & & & 0850 & 2.5 & 19.5 & 471 & 1.0 & 7.8 & \\
\hline & & & 0852 & 3.0 & 18.0 & 534 & 0.2 & 6.9 & \\
\hline & & & 0856 & 3.5 & 16.4 & 606 & 0.2 & 6.3 & \\
\hline & & & 0857 & 3.6 & 16.4 & 614 & 0.2 & 6.2 & \\
\hline & & 20021029 & 1013 & 0.1 & 8.1 & 444 & 9.2 & & \\
\hline & & & 1014 & 1.0 & 8.1 & 445 & 9.2 & 9.7 & \\
\hline & & & 1014 & 1.5 & 8.1 & 444 & 9.2 & & \\
\hline & & & 1015 & 2.0 & 8.1 & 445 & 9.3 & & \\
\hline & & & 1016 & 2.5 & 8.1 & 445 & 9.5 & & \\
\hline & & & 1016 & 3.0 & 8.1 & 445 & 9.5 & & \\
\hline & & & 1017 & 3.2 & 8.1 & 445 & 9.4 & & \\
\hline & & 20030528 & 1000 & 0.1 & 17.9 & 375 & 9.4 & & \\
\hline & & & 1001 & 0.5 & 17.8 & 373 & 9.5 & & \\
\hline & & & 1002 & 1.0 & 17.7 & 372 & 9.6 & 9.4 & 1.2 \\
\hline & & & 1003 & 1.5 & 17.5 & 371 & 9.6 & & \\
\hline & & & 1004 & 2.0 & 17.4 & 370 & 9.7 & & \\
\hline & & & 1005 & 2.5 & 17.2 & 369 & 9.6 & & \\
\hline & & & 1006 & 3.0 & 15.8 & 389 & 7.9 & 9.6 & 1.3 \\
\hline & & & 1007 & 3.5 & 14.5 & 421 & 5.6 & & \\
\hline & & & 1008 & 3.7 & 13.4 & 474 & 3.5 & & \\
\hline & & 20030813 & 0820 & 0.1 & 18.3 & 429 & 6.5 & 9.1 & \\
\hline & & & 0822 & 0.5 & 18.3 & 429 & 6.3 & 9.5 & \\
\hline & & & 0823 & 1.0 & 18.3 & 428 & 6.0 & 9.6 & 4.1 \\
\hline & & & 0824 & 1.5 & 18.2 & 428 & 6.2 & 9.6 & \\
\hline & & & 0825 & 2.0 & 18.2 & 472 & 0.6 & 9.4 & \\
\hline & & & 0827 & 2.5 & 17.5 & 632 & 0.3 & 8.2 & \\
\hline & & & 0828 & 3.0 & 16.5 & 678 & 0.3 & 7.8 & 20.2 \\
\hline & & & 0830 & 3.5 & 14.3 & 788 & 0.3 & 7.3 & \\
\hline & & & 0831 & 3.7 & 13.6 & 848 & 0.3 & 7.2 & \\
\hline
\end{tabular}


Appendix A. Physical and chemical profile data collected from study area lakes, 2002-03—Continued

[Abbreviations: $\mathrm{m}$, meters; ${ }^{\circ} \mathrm{C}$, degrees Celsius; $\mu \mathrm{S} / \mathrm{cm}$, microsiemens per centimeter; $\mathrm{mg} / \mathrm{L}$, milligrams per liter; std, standard; NTU, nephelometric turbidity units]

\begin{tabular}{|c|c|c|c|c|c|c|c|c|c|}
\hline $\begin{array}{c}\text { Site no. } \\
\text { (see } \\
\text { fig. 2) }\end{array}$ & Station name & $\begin{array}{c}\text { Date } \\
\text { (yyyymmdd) }\end{array}$ & Time & $\begin{array}{l}\text { Depth } \\
\text { (m) }\end{array}$ & $\begin{array}{l}\text { Water } \\
\text { temp- } \\
\text { erature } \\
\quad\left({ }^{\circ} \mathrm{C}\right)\end{array}$ & $\begin{array}{l}\text { Specific } \\
\text { cond- } \\
\text { uctance } \\
(\mu \mathrm{S} / \mathrm{cm} \\
\left.\text { at } 25^{\circ} \mathrm{C}\right)\end{array}$ & $\begin{array}{c}\text { Dis- } \\
\text { solved } \\
\text { oxygen } \\
(\mathrm{mg} / \mathrm{L})\end{array}$ & (std. units) & $\begin{array}{l}\text { Turb- } \\
\text { idity } \\
\text { (NTU) }\end{array}$ \\
\hline \multirow[t]{8}{*}{14} & Spooner Lake near center & 20031014 & 1042 & 0.1 & 10.9 & 476 & 7.8 & 7.8 & \\
\hline & & & 1043 & 0.5 & 10.9 & 476 & 8.0 & 8.1 & \\
\hline & & & 1045 & 1.0 & 10.9 & 476 & 7.7 & 8.3 & 5.5 \\
\hline & & & 1046 & 1.5 & 10.8 & 480 & 6.1 & 8.4 & \\
\hline & & & 1048 & 2.0 & 10.9 & 480 & 6.6 & 8.5 & \\
\hline & & & 1050 & 2.5 & 10.8 & 482 & 5.5 & 8.5 & 11.8 \\
\hline & & & 1051 & 3.0 & 11.0 & 559 & 2.4 & 8.2 & \\
\hline & & & 1052 & 3.4 & 11.8 & 745 & 0.6 & 7.6 & \\
\hline \multirow[t]{8}{*}{15} & Spooner Lake, north & 20020731 & 1055 & 0.2 & 22.4 & 394 & 9.1 & 10.5 & \\
\hline & & & 1057 & 0.5 & 22.3 & 395 & 9.2 & 10.5 & \\
\hline & & & 1059 & 1.0 & 21.5 & 386 & 7.8 & 10.2 & \\
\hline & & & 1100 & 1.5 & 21.4 & 385 & 6.8 & 10.1 & \\
\hline & & & 1104 & 2.0 & 20.0 & 387 & 0.3 & 9.0 & \\
\hline & & & 1106 & 2.5 & 18.7 & 407 & 0.1 & 8.6 & \\
\hline & & & 1107 & 3.0 & 16.9 & 518 & 0.1 & 7.6 & \\
\hline & & & 1109 & 3.1 & 16.5 & 584 & 0.2 & 6.9 & \\
\hline \multirow[t]{3}{*}{16} & Spooner Lake, west & 20020731 & 1253 & 0.2 & 22.6 & 393 & 9.5 & 10.7 & \\
\hline & & & 1255 & 0.5 & 22.0 & 394 & 10.0 & 10.6 & \\
\hline & & & 1257 & 1.0 & 20.7 & 379 & 7.0 & 10.5 & \\
\hline \multirow[t]{8}{*}{17} & Marlette Lake, south & 20020801 & 1204 & 0.1 & 20.3 & 40.7 & 7.6 & & \\
\hline & & & 1206 & 1.0 & 20.0 & 40.7 & 7.8 & & \\
\hline & & & 1207 & 2.0 & 19.6 & 40.6 & 7.6 & & \\
\hline & & & 1208 & 3.0 & 19.5 & 40.6 & 7.5 & & \\
\hline & & & 1209 & 4.0 & 19.4 & 40.6 & 7.5 & & \\
\hline & & & 1210 & 5.0 & 19.4 & 40.6 & 7.5 & & \\
\hline & & & 1212 & 6.0 & 19.4 & 40.6 & 7.3 & & \\
\hline & & & 1213 & 6.6 & 19.2 & 40.8 & 8.8 & & \\
\hline \multirow[t]{8}{*}{18} & Marlette Lake, southeast & 20020801 & 1132 & 0.1 & 19.7 & 40.8 & 7.3 & & \\
\hline & & & 1133 & 1.0 & 19.6 & 40.7 & 7.3 & & \\
\hline & & & 1134 & 2.0 & 19.4 & 40.6 & 7.3 & & \\
\hline & & & 1135 & 3.0 & 19.4 & 40.6 & 7.2 & & \\
\hline & & & 1136 & 4.0 & 19.3 & 40.6 & 7.2 & & \\
\hline & & & 1137 & 5.0 & 19.3 & 40.6 & 7.1 & & \\
\hline & & & 1139 & 6.0 & 19.2 & 40.6 & 7.1 & & \\
\hline & & & 1140 & 6.7 & 19.2 & 40.9 & 6.2 & & \\
\hline
\end{tabular}


Appendix A. Physical and chemical profile data collected from study area lakes, 2002-03-Continued

[Abbreviations: $\mathrm{m}$, meters; ${ }^{\circ} \mathrm{C}$, degrees Celsius; $\mu \mathrm{S} / \mathrm{cm}$, microsiemens per centimeter; $\mathrm{mg} / \mathrm{L}$, milligrams per liter; std, standard; NTU, nephelometric turbidity units]

\begin{tabular}{|c|c|c|c|c|c|c|c|c|c|}
\hline $\begin{array}{c}\text { Site no. } \\
\text { (see } \\
\text { fig. 2) }\end{array}$ & Station name & $\begin{array}{c}\text { Date } \\
\text { (yyyymmdd) }\end{array}$ & Time & Depth & $\begin{array}{l}\text { Water } \\
\text { temp- } \\
\text { erature }\end{array}$ & $\begin{array}{l}\text { Specific } \\
\text { cond- } \\
\text { uctance } \\
(\mu S / \mathrm{cm} \\
\left.\text { at } 25^{\circ} \mathrm{C}\right)\end{array}$ & $\begin{array}{c}\text { Dis- } \\
\text { solved } \\
\text { oxygen } \\
\text { (mg/L) }\end{array}$ & (std. units) & $\begin{array}{l}\text { Turb- } \\
\text { idity } \\
\text { (NTU) }\end{array}$ \\
\hline \multirow[t]{39}{*}{19} & Marlette Lake near center & 20020604 & 1044 & 0.2 & 13.7 & 36.3 & 5.1 & & \\
\hline & & & 1045 & 1.0 & 13.2 & 36.2 & 3.8 & & \\
\hline & & & 1046 & 2.0 & 12.9 & 36.1 & 3.6 & & \\
\hline & & & 1047 & 3.0 & 12.2 & 36.0 & 3.4 & & \\
\hline & & & 1048 & 4.0 & 11.0 & 35.9 & 3.2 & & \\
\hline & & & 1049 & 5.0 & 10.1 & 35.7 & 3.2 & & \\
\hline & & & 1050 & 6.0 & 9.4 & 35.8 & 3.0 & & \\
\hline & & & 1051 & 7.0 & 8.8 & 35.7 & 2.8 & & \\
\hline & & & 1052 & 8.0 & 7.9 & 35.6 & 2.5 & & \\
\hline & & & 1053 & 9.0 & 7.2 & 35.7 & 2.2 & & \\
\hline & & & 1054 & 10.0 & 6.9 & 35.6 & 2.1 & & \\
\hline & & & 1101 & 10.9 & 6.6 & 37.4 & 1.6 & & \\
\hline & & 20020801 & 0857 & 0.1 & 19.5 & 41.2 & 7.3 & & \\
\hline & & & 0859 & 1.0 & 19.4 & 41.1 & 7.4 & & \\
\hline & & & 0900 & 2.0 & 19.4 & 41.1 & 7.2 & & \\
\hline & & & 0902 & 3.0 & 19.4 & 41.0 & 7.2 & & \\
\hline & & & 0903 & 4.0 & 19.3 & 41.0 & 7.2 & & \\
\hline & & & 0904 & 5.0 & 19.2 & 40.9 & 7.3 & & \\
\hline & & & 0905 & 6.0 & 18.9 & 40.8 & 7.4 & & \\
\hline & & & 0906 & 7.0 & 18.3 & 40.7 & 7.5 & & \\
\hline & & & 0907 & 8.0 & 16.6 & 41.0 & 8.4 & & \\
\hline & & & 0908 & 8.5 & 14.9 & 41.9 & 7.4 & & \\
\hline & & & 0909 & 9.0 & 12.6 & 44.3 & 4.7 & & \\
\hline & & & 0910 & 10.0 & 11.3 & 45.2 & 2.0 & & \\
\hline & & & 0911 & 11.0 & 10.5 & 45.7 & 0.4 & & \\
\hline & & & 0912 & 12.0 & 9.8 & 55.5 & 0.1 & & \\
\hline & & & 0913 & 12.1 & 9.8 & 58.3 & 0.1 & & \\
\hline & & 20021022 & 0945 & 0.1 & 10.0 & 42.6 & 7.5 & & \\
\hline & & & 0946 & 1.0 & 9.9 & 42.0 & 7.4 & 7.3 & 3.3 \\
\hline & & & 0947 & 2.0 & 9.9 & 41.8 & 7.4 & & \\
\hline & & & 0948 & 3.0 & 9.8 & 41.6 & 7.3 & & \\
\hline & & & 0951 & 4.0 & 9.8 & 41.4 & 7.2 & & \\
\hline & & & 0952 & 5.0 & 9.8 & 41.2 & 7.2 & 7.3 & 2.8 \\
\hline & & & 0953 & 6.0 & 9.8 & 41.1 & 7.2 & & \\
\hline & & & 0954 & 7.0 & 9.8 & 40.9 & 7.2 & & \\
\hline & & & 0956 & 8.0 & 9.8 & 40.8 & 7.2 & & \\
\hline & & & 0958 & 9.0 & 9.8 & 40.7 & 7.2 & & \\
\hline & & & 0959 & 10.0 & 9.8 & 40.6 & 7.2 & & \\
\hline & & & 1000 & 10.1 & 9.8 & 40.4 & 7.1 & & \\
\hline
\end{tabular}


Appendix A. Physical and chemical profile data collected from study area lakes, 2002-03-Continued

[Abbreviations: $\mathrm{m}$, meters; ${ }^{\circ} \mathrm{C}$, degrees Celsius; $\mu \mathrm{S} / \mathrm{cm}$, microsiemens per centimeter; $\mathrm{mg} / \mathrm{L}$, milligrams per liter; std, standard; NTU, nephelometric std, standard; NTU, nephelometric turbidity units]

\begin{tabular}{|c|c|c|c|c|c|c|c|c|c|}
\hline $\begin{array}{l}\text { Site no. } \\
\text { (see } \\
\text { fig. 2) }\end{array}$ & Station name & $\begin{array}{c}\text { Date } \\
\text { (yyyymmdd) }\end{array}$ & Time & $\begin{array}{l}\text { Depth } \\
(\mathrm{m})\end{array}$ & $\begin{array}{c}\text { Water } \\
\text { temp- } \\
\text { erature } \\
\left({ }^{\circ} \mathrm{C}\right)\end{array}$ & $\begin{array}{l}\text { Specific } \\
\text { cond- } \\
\text { uctance } \\
(\mu \mathrm{S} / \mathrm{cm} \\
\left.\text { at } 25^{\circ} \mathrm{C}\right)\end{array}$ & $\begin{array}{c}\text { Dis- } \\
\text { solved } \\
\text { oxygen } \\
(\mathrm{mg} / \mathrm{L})\end{array}$ & $\begin{array}{c}\mathrm{pH} \\
\text { (std. units) }\end{array}$ & $\begin{array}{l}\text { Turb- } \\
\text { idity } \\
\text { (NTU) }\end{array}$ \\
\hline \multirow[t]{33}{*}{19} & Marlette Lake near center & 20030619 & 0910 & 0.1 & 16.1 & 42.6 & 7.7 & & \\
\hline & & & 0911 & 1.0 & 16.1 & 42.5 & 7.6 & 7.3 & 0.7 \\
\hline & & & 0912 & 2.0 & 16.1 & 42.3 & 7.6 & & \\
\hline & & & 0913 & 3.0 & 15.8 & 42.2 & 7.9 & & \\
\hline & & & 0914 & 4.0 & 14.2 & 41.7 & 8.8 & & \\
\hline & & & 0915 & 5.0 & 11.3 & 41.4 & 10.1 & & \\
\hline & & & 0916 & 6.0 & 9.0 & 40.9 & 10.0 & & \\
\hline & & & 0917 & 7.0 & 7.4 & 40.5 & 9.5 & & \\
\hline & & & 0918 & 8.0 & 6.6 & 40.4 & 9.0 & & \\
\hline & & & 0919 & 9.0 & 5.6 & 42.0 & 5.6 & 7.3 & 1.2 \\
\hline & & & 0920 & 10.0 & 5.4 & 42.4 & 4.9 & & \\
\hline & & & 0921 & 10.7 & 5.4 & 44.0 & 0.4 & & \\
\hline & & 20030811 & 0941 & 0.1 & 18.2 & 42.4 & 7.0 & 7.8 & \\
\hline & & & 0942 & 1.0 & 18.2 & 42.4 & 7.0 & 7.8 & 0.5 \\
\hline & & & 0944 & 2.0 & 18.1 & 42.5 & 6.9 & 7.8 & \\
\hline & & & 0945 & 3.0 & 18.1 & 42.5 & 6.9 & 7.8 & \\
\hline & & & 0946 & 4.0 & 18.1 & 42.4 & 6.9 & 7.8 & \\
\hline & & & 0947 & 5.0 & 18.1 & 42.4 & 6.9 & 7.8 & \\
\hline & & & 0948 & 6.0 & 18.1 & 42.5 & 6.8 & 7.8 & \\
\hline & & & 0949 & 7.0 & 18.0 & 42.5 & 6.9 & 7.8 & \\
\hline & & & 0950 & 8.0 & 15.2 & 42.4 & 8.8 & 7.8 & \\
\hline & & & 0952 & 9.0 & 11.2 & 43.2 & 8.5 & 7.8 & 0.8 \\
\hline & & & 0953 & 10.0 & 9.1 & 45.2 & 4.8 & 7.7 & \\
\hline & & & 0955 & 10.6 & 8.7 & 46.0 & 3.0 & 7.6 & \\
\hline & & 20031021 & 0938 & 0.1 & 11.4 & 43.1 & 9.4 & 6.4 & \\
\hline & & & 0939 & 1.0 & 11.4 & 43.1 & 8.8 & 6.7 & 3.2 \\
\hline & & & 0941 & 2.0 & 11.4 & 43.2 & 8.7 & 6.7 & \\
\hline & & & 0942 & 3.0 & 11.4 & 43.1 & 8.4 & 6.6 & \\
\hline & & & 0943 & 4.0 & 11.4 & 43.1 & 8.3 & 6.5 & \\
\hline & & & 0944 & 5.0 & 11.4 & 43.1 & 8.4 & 6.4 & 1.8 \\
\hline & & & 0945 & 7.0 & 11.4 & 43.0 & 8.2 & 6.5 & \\
\hline & & & 0946 & 9.0 & 11.4 & 43.0 & 8.2 & 6.5 & \\
\hline & & & 0948 & 10.4 & 11.4 & 44.0 & 6.3 & 6.8 & \\
\hline
\end{tabular}


Appendix A. Physical and chemical profile data collected from study area lakes, 2002-03 —Continued

[Abbreviations: $\mathrm{m}$, meters; ${ }^{\circ} \mathrm{C}$, degrees Celsius; $\mu \mathrm{S} / \mathrm{cm}$, microsiemens per centimeter; $\mathrm{mg} / \mathrm{L}$, milligrams per liter; std, standard; NTU, nephelometric turbidity units]

\begin{tabular}{|c|c|c|c|c|c|c|c|c|}
\hline $\begin{array}{l}\text { Site no. } \\
\text { (see } \\
\text { fig. 2) }\end{array}$ & Station name & $\begin{array}{c}\text { Date } \\
\text { (yyyymmdd) }\end{array}$ & Time & $\begin{array}{l}\text { Depth } \\
(\mathrm{m})\end{array}$ & $\begin{array}{l}\text { Water } \\
\text { temp- } \\
\text { erature } \\
\left({ }^{\circ} \mathrm{C}\right)\end{array}$ & $\begin{array}{l}\text { Specific } \\
\text { cond- } \\
\text { uctance } \\
(\mu S / \mathrm{cm} \\
\left.\text { at } 25^{\circ} \mathrm{C}\right)\end{array}$ & $\begin{array}{l}\text { Dis- } \\
\text { solved } \\
\text { oxygen } \quad \mathrm{pH} \\
(\mathrm{mg} / \mathrm{L}) \text { (std. units) }\end{array}$ & $\begin{array}{l}\text { Turb- } \\
\text { idity } \\
\text { (NTU) }\end{array}$ \\
\hline \multirow[t]{11}{*}{20} & Marlette Lake, east & 20020801 & 1056 & 0.1 & 19.8 & 40.6 & 7.2 & \\
\hline & & & 1057 & 1.0 & 19.7 & 40.7 & 7.2 & \\
\hline & & & 1058 & 2.0 & 19.5 & 40.6 & 7.2 & \\
\hline & & & 1059 & 3.0 & 19.4 & 40.6 & 7.2 & \\
\hline & & & 1100 & 4.0 & 19.4 & 40.6 & 7.1 & \\
\hline & & & 1101 & 5.0 & 19.4 & 40.6 & 7.1 & \\
\hline & & & 1102 & 6.0 & 18.8 & 40.6 & 7.4 & \\
\hline & & & 1103 & 7.0 & 18.3 & 40.5 & 7.5 & \\
\hline & & & 1105 & 8.0 & 16.1 & 41.5 & 7.6 & \\
\hline & & & 1106 & 9.0 & 13.6 & 43.4 & 5.9 & \\
\hline & & & 1107 & 9.2 & 13.2 & 43.6 & 5.6 & \\
\hline \multirow[t]{16}{*}{21} & Marlette Lake, north & 20020801 & 1012 & 0.1 & 19.5 & 40.7 & 7.3 & \\
\hline & & & 1013 & 1.0 & 19.4 & 40.7 & 7.3 & \\
\hline & & & 1014 & 2.0 & 19.3 & 40.7 & 7.3 & \\
\hline & & & 1015 & 3.0 & 19.3 & 40.7 & 7.2 & \\
\hline & & & 1016 & 4.0 & 19.3 & 40.7 & 7.2 & \\
\hline & & & 1018 & 5.0 & 19.2 & 40.6 & 7.2 & \\
\hline & & & 1019 & 6.0 & 19.0 & 40.7 & 7.1 & \\
\hline & & & 1020 & 7.0 & 17.8 & 40.8 & 7.7 & \\
\hline & & & 1021 & 8.0 & 16.3 & 41.1 & 8.3 & \\
\hline & & & 1022 & 9.0 & 14.0 & 42.2 & 7.8 & \\
\hline & & & 1024 & 9.5 & 12.2 & 44.2 & 3.7 & \\
\hline & & & 1025 & 10.0 & 11.4 & 44.8 & 2.0 & \\
\hline & & & 1026 & 10.5 & 10.9 & 45.2 & 1.3 & \\
\hline & & & 1027 & 11.0 & 10.4 & 45.1 & 0.8 & \\
\hline & & & 1028 & 12.0 & 9.5 & 57.0 & 0.1 & \\
\hline & & & 1030 & 12.7 & 9.3 & 72.0 & 0.1 & \\
\hline
\end{tabular}




\section{Appendix B. Nutrient concentrations in water samples and field data collected at study area lake sites, 2002-03}

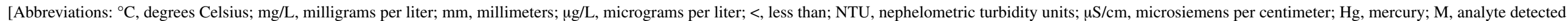
but not quantified; na, not analyzed]

\begin{tabular}{|c|c|c|c|c|c|c|c|c|c|c|c|c|c|c|c|c|c|c|}
\hline \multirow[t]{2}{*}{$\begin{array}{c}\text { Site } \\
\text { no. } \\
\text { (see } \\
\text { fig. 2) }\end{array}$} & \multirow[t]{2}{*}{ Station name } & \multirow[t]{2}{*}{$\begin{array}{c}\text { Date } \\
\text { (yyyymmdd) }\end{array}$} & \multirow[t]{2}{*}{ Time } & $\begin{array}{l}\text { Sampl- } \\
\text { ing } \\
\text { depth }\end{array}$ & $\begin{array}{c}\text { Trans- } \\
\text { parency } \\
\text { Secchi } \\
\text { disc }\end{array}$ & \multirow{2}{*}{$\begin{array}{c}\begin{array}{c}\text { Turb- } \\
\text { idity } \\
\text { (NTU) }\end{array} \\
\text { (NTU) }\end{array}$} & \multirow{2}{*}{$\begin{array}{c}\begin{array}{c}\text { Baro- } \\
\text { metric } \\
\text { pressure }\end{array} \\
(\mathrm{mm} \mathrm{Hg})\end{array}$} & \multirow{2}{*}{$\begin{array}{c}\begin{array}{c}\text { Dissolved } \\
\text { oxygen }\end{array} \\
(\mathrm{mg} / \mathrm{L})\end{array}$} & \multirow{2}{*}{$\begin{array}{c}\mathrm{pH} \\
\text { (units) }\end{array}$} & \multirow{2}{*}{$\begin{array}{c}\text { Specific } \\
\text { conduc- } \\
\text { tance }\end{array}$} & $\begin{array}{l}\text { Air } \\
\text { temp- } \\
\text { erature }\end{array}$ & $\begin{array}{l}\text { Water } \\
\text { temp- } \\
\text { erature }\end{array}$ & $\begin{array}{c}\text { Total } \\
\text { Kjeldahl } \\
\text { nitrogen } \\
\text { unfiltered }\end{array}$ & $\begin{array}{c}\text { Ammo } \\
\text { nia, } \\
\text { filtered }\end{array}$ & $\begin{array}{l}\text { Nitrate }{ }^{a} \text {, } \\
\text { filtered }\end{array}$ & $\begin{array}{l}\text { Ortho- } \\
\text { phos- } \\
\text { phate, } \\
\text { filtered }\end{array}$ & $\begin{array}{l}\text { Phos- } \\
\text { phorus, } \\
\text { unfiltered }\end{array}$ & \multirow{2}{*}{\begin{tabular}{|c|} 
Iron \\
(bio- \\
reac- \\
tive), \\
unfiltered \\
$(\mu \mathrm{g} / \mathrm{L}$ as \\
$\mathrm{Fe})$ \\
\end{tabular}} \\
\hline & & & & \multicolumn{2}{|c|}{ (meters) } & & & & & & \multicolumn{2}{|c|}{ (degrees Celsius) } & \multicolumn{3}{|c|}{$(\mu \mathrm{g} / \mathrm{L}$ as $N)$} & \multicolumn{2}{|c|}{$(\mu \mathrm{g} / \mathrm{L}$ as $P)$} & \\
\hline \multirow[t]{2}{*}{1} & Lower Echo Lake, east & 20020822 & 1240 & 1 & 9 & na & 585 & 7.2 & na & 6 & 23.0 & 17.6 & 144 & 6.1 & 5.6 & $<1.0$ & 2.9 & 14.4 \\
\hline & & 20020822 & 1300 & 13 & 9 & na & 585 & 10.3 & na & 6 & 23.0 & 9.1 & 118 & 4.0 & 4.3 & $<1.0$ & 4.1 & 28.3 \\
\hline \multirow[t]{12}{*}{2} & Lower Echo Lake near center & 20020529 & 1345 & 12 & 7 & na & 588 & 8.4 & na & 6 & na & 5.7 & 202 & 5.6 & 10.4 & $<1.0$ & 4.9 & 38.8 \\
\hline & & 20020529 & 1430 & 5 & 7 & na & 588 & 8.6 & na & 6 & na & 6.7 & 140 & 18.8 & 16.0 & $<1.0$ & 4.6 & 33.7 \\
\hline & & 20020822 & 0920 & 1 & 10.3 & na & 585 & 7.0 & na & 7 & 15.0 & 17.1 & 75 & 8.6 & 6.0 & $<1.0$ & 2.6 & 14.7 \\
\hline & & 20020822 & 0940 & 12 & 10.3 & na & 585 & 9.7 & na & 7 & 15.0 & 10.5 & 100 & 8.9 & 7.5 & $<1.0$ & 4.1 & 30.7 \\
\hline & & 20021030 & 0930 & 1 & 9.5 & 0.5 & 580 & 7.8 & 6.6 & 7 & 6.0 & 9.7 & 78 & $<3.0$ & 4.8 & 1.4 & 5.1 & 19.3 \\
\hline & & 20021030 & 1000 & 9 & 9.5 & 0.2 & 580 & 7.7 & 7.0 & 7 & 6.0 & 9.7 & 166 & $<3.0$ & 4.0 & 2.1 & 5.4 & 18.9 \\
\hline & & 20030617 & 1020 & 1 & 7 & 0.4 & 583 & 8.6 & 7.6 & 7 & 21.0 & 14.5 & 80 & $<3.0$ & 10.4 & 2.6 & 5.8 & 30.5 \\
\hline & & 20030617 & 1050 & 8 & 7 & 0.4 & 583 & 9.8 & 7.6 & 7 & 21.0 & 6.9 & 80 & $<3.0$ & 6.4 & 1.2 & 5.8 & 35.7 \\
\hline & & 20030819 & 1015 & 1 & 8.3 & 0.4 & 586 & 9.0 & 9.3 & 6 & 22.5 & 18.0 & 108 & 11 & 4.5 & $<1.0$ & 4.5 & 13.4 \\
\hline & & 20030819 & 1030 & 12 & 8.3 & 0.5 & 586 & 10.5 & 7.0 & 6 & 22.5 & 8.3 & 126 & 5.8 & 3.3 & $<1.0$ & 4.5 & 18.7 \\
\hline & & 20031020 & 0930 & 1 & 7.5 & 0.5 & 588 & 9.8 & 9.0 & 7 & 14.5 & 11.4 & 103 & 8.5 & 6.6 & $<1.0$ & 4.2 & 16.9 \\
\hline & & 20031020 & 0945 & 16 & 7.5 & 0.4 & 588 & 7.7 & 7.0 & 7 & 14.5 & 8.4 & 110 & $<3.0$ & 2.0 & $<1.0$ & 4.5 & 21.2 \\
\hline 3 & Lower Echo Lake, southwest & 20020822 & 1010 & 1 & $>4.3$ & na & 585 & 7.1 & na & 7 & 22.0 & 17.0 & 84 & 6.6 & 3.8 & $<1.0$ & 3.2 & 17.5 \\
\hline \multirow[t]{2}{*}{4} & Lower Echo Lake, northwest & 20020822 & 1140 & 1 & 9.5 & na & 585 & 7.1 & na & 7 & 20.5 & 17.2 & 96 & 4.5 & 4.6 & $<1.0$ & 2.6 & 17.0 \\
\hline & & 20020822 & 1200 & 13 & 9.5 & na & 585 & 9.8 & na & 7 & 20.5 & 9.4 & 151 & $<3.0$ & 3.2 & $<1.0$ & 4.4 & 34.7 \\
\hline \multirow[t]{8}{*}{5} & Upper Echo Lake near center & 20020530 & 1145 & 5 & $>7$ & na & 585 & 8.8 & na & 5 & na & 5.0 & 166 & $<3.0$ & 34.5 & $<1.0$ & 4.0 & 55.5 \\
\hline & & 20020530 & 1300 & 2 & $>7$ & na & 585 & 8.7 & na & 5 & na & 6.1 & 165 & 7.7 & 39.9 & $<1.0$ & 5.2 & 63.2 \\
\hline & & 20020826 & 1130 & 1 & 6.5 & na & 588 & 6.8 & na & 5 & 21.5 & 17.6 & 116 & 7.5 & 5.1 & $<1.0$ & 5.0 & 33.0 \\
\hline & & 20020826 & 1150 & 10 & 6.5 & na & 588 & 8.6 & na & 5 & 21.5 & 10.1 & 148 & 9.3 & 6.0 & $<1.0$ & 7.5 & 110.8 \\
\hline & & 20030617 & 1150 & 1 & 6.2 & 0.2 & 583 & 9.0 & 8.8 & 5 & 23.0 & 11.4 & 56 & $<3.0$ & 18.0 & 1.5 & 4.6 & 20.5 \\
\hline & & 20030617 & 1215 & 4 & 6.2 & 0.5 & 583 & 10.1 & 8.8 & 5 & 23.0 & 7.6 & 70 & $<3.0$ & 14.6 & 1.7 & 5.5 & 20.9 \\
\hline & & 20030819 & 1110 & 1 & 6.5 & 0.5 & 586 & 8.7 & 7.1 & 5 & 22.0 & 18.5 & 90 & 5.8 & 3.5 & $<1.0$ & 5.7 & 25.1 \\
\hline & & 20030819 & 1130 & 6 & 6.5 & 0.5 & 586 & 7.8 & 6.9 & 5 & 22.0 & 16.6 & 102 & 5.8 & 3.5 & $<1.0$ & 6.0 & 30.9 \\
\hline \multirow[t]{3}{*}{6} & Upper Echo Lake, east & 20020826 & 1010 & 1 & 7 & na & 588 & 6.9 & na & 5 & 18.5 & 17.4 & 117 & 7.7 & 5.1 & $<1.0$ & 5.3 & 32.6 \\
\hline & & 20020826 & 1030 & 10 & 7 & na & 588 & 9.9 & na & 5 & 18.5 & 9.2 & 359 & 4.7 & 3.6 & $<1.0$ & 6.0 & 32.3 \\
\hline & & 20020826 & 1045 & 22 & 7 & na & 588 & 2.8 & na & 8 & 18.5 & 5.0 & 55 & 9.1 & 31.0 & $<1.0$ & 7.5 & 200.7 \\
\hline
\end{tabular}


Appendix B. Nutrient concentrations in water samples and field data collected at study area lake sites, 2002-03-Continued

\begin{tabular}{|c|c|c|c|c|c|c|c|c|c|c|c|c|c|c|c|c|c|c|}
\hline \multirow{2}{*}{$\begin{array}{l}\text { Site } \\
\text { no. } \\
\text { (see } \\
\text { fig. 2) }\end{array}$} & \multirow[t]{2}{*}{ Station name } & \multirow[t]{2}{*}{$\begin{array}{c}\text { Date } \\
\text { (yyyymmdd) }\end{array}$} & \multirow[t]{2}{*}{ Time } & $\begin{array}{l}\text { Sampl- } \\
\text { ing } \\
\text { depth }\end{array}$ & $\begin{array}{c}\text { Trans- } \\
\text { parency } \\
\text { Secchi } \\
\text { disc }\end{array}$ & \multirow{2}{*}{$\begin{array}{l}\begin{array}{c}\text { Turb- } \\
\text { idity } \\
\text { (NTU) }\end{array} \\
\text { (NTU) }\end{array}$} & \multirow{2}{*}{$\begin{array}{c}\begin{array}{c}\text { Baro- } \\
\text { metric } \\
\text { pressure }\end{array} \\
(\mathrm{mm} \mathrm{Hg})\end{array}$} & \multirow{2}{*}{$\begin{array}{c}\begin{array}{c}\text { Dissolved } \\
\text { oxygen }\end{array} \\
\text { (mg/L) } \\
\end{array}$} & \multirow{2}{*}{$\begin{array}{c}\mathrm{pH} \\
\text { (units) }\end{array}$} & \multirow{2}{*}{$\begin{array}{c}\begin{array}{c}\text { Specific } \\
\text { conduc- } \\
\text { tance }\end{array} \\
(\mu S / \mathrm{cm} \\
\left.\text { at } 25^{\circ} \mathrm{C}\right)\end{array}$} & $\begin{array}{c}\text { Air } \\
\text { temp- } \\
\text { erature }\end{array}$ & $\begin{array}{l}\text { Water } \\
\text { temp- } \\
\text { erature }\end{array}$ & $\begin{array}{c}\text { Total } \\
\text { Kjeldahl } \\
\text { nitrogen } \\
\text { unfiltered }\end{array}$ & $\begin{array}{c}\text { Ammo } \\
\text { nia, } \\
\text { filtered }\end{array}$ & $\begin{array}{l}\text { Nitrate } \\
\text { filtered }\end{array}$ & $\begin{array}{l}\text { Ortho- } \\
\text { phos- } \\
\text { phate, } \\
\text { filtered }\end{array}$ & $\begin{array}{l}\text { Phos- } \\
\text { phorus, } \\
\text { unfiltered }\end{array}$ & \multirow{2}{*}{$\begin{array}{c}\text { Iron } \\
\text { (bio- } \\
\text { reac- } \\
\text { tive), } \\
\text { unfiltered } \\
(\mu \mathrm{g} / \mathrm{L} \text { as } \\
\mathrm{Fe}) \\
\end{array}$} \\
\hline & & & & \multicolumn{2}{|c|}{ (meters) } & & & & & & \multicolumn{2}{|c|}{ (degrees Celsius) } & \multicolumn{3}{|c|}{$(\mu \mathrm{g} / \mathrm{L}$ as $\mathrm{N})$} & \multicolumn{2}{|c|}{$(\mu \mathrm{g} / \mathrm{L}$ as $P)$} & \\
\hline \multirow[t]{2}{*}{7} & Upper Echo Lake, Southwest & 20020826 & 1245 & 1 & 7 & na & 588 & 6.9 & na & 5 & 21.5 & 17.4 & 108 & 9.3 & 7.0 & $<1.0$ & 5.0 & 32.3 \\
\hline & & 20020826 & 1300 & 8 & 7 & na & 588 & 9.0 & na & 5 & 21.5 & 13.0 & 112 & 6.1 & 5.0 & $<1.0$ & 6.0 & 42.2 \\
\hline 8 & Upper Echo Lake near inlet & 20020826 & 1330 & 1 & $>1.2$ & na & 588 & 7.1 & na & 5 & 23.0 & 18.1 & 99 & 6.3 & 5.3 & $<1.0$ & 5.0 & 33.7 \\
\hline \multirow[t]{2}{*}{9} & Fallen Leaf Lake, north & 20020814 & 1250 & 1 & 14.6 & na & 608 & 9.6 & na & 20 & 26.0 & 20.2 & 68 & 5.9 & 3.6 & $<1.0$ & 2.5 & 8.3 \\
\hline & & 20020814 & 1320 & 20 & 14.6 & na & 608 & 13.2 & na & 19 & 26.0 & 8.2 & 101 & 6.2 & 3.6 & $<1.0$ & 2.8 & na \\
\hline \multirow[t]{12}{*}{10} & Fallen Leaf Lake near center & 20020603 & 1150 & 20 & 14.1 & na & 606 & 8.9 & na & 19 & 16.5 & 7.5 & 170 & 5.8 & 4.8 & $<1.0$ & 4.6 & 34.7 \\
\hline & & 20020603 & 1215 & 2 & 14.1 & na & 606 & 8.7 & na & 19 & 16.5 & 11.8 & 254 & 4.2 & 3.4 & $<1.0$ & 2.1 & 31.6 \\
\hline & & 20020814 & 1140 & 20 & 15.6 & na & 608 & 13.8 & na & 20 & 22.0 & 8.9 & 68 & 7.8 & 5.1 & $<1.0$ & 4.4 & 7.1 \\
\hline & & 20020814 & 1200 & 25 & 15.6 & na & 608 & 13.8 & na & 20 & 22.0 & 7.7 & 57 & 6.2 & 4.4 & $<1.0$ & 4.1 & 8.1 \\
\hline & & 20021028 & 1200 & 1 & 16.2 & 0.2 & 605 & 8.0 & 7.9 & 22 & 14.0 & 12.5 & 40 & $<3.0$ & 3.1 & 1.0 & 5.4 & 9.4 \\
\hline & & 20021028 & 1230 & 30 & 16.2 & 0.2 & 605 & 9.6 & 7.8 & 20 & 14.0 & 6.9 & $<35$ & 3.3 & 4.0 & 1.0 & 3.9 & 7.5 \\
\hline & & 20030529 & 0945 & 1 & 12.2 & 0.2 & 606 & 8.6 & 7.4 & 21 & 18.0 & 11.3 & 38 & 4.6 & 3.4 & 1.2 & 3.7 & 6.1 \\
\hline & & 20030529 & 1000 & 20 & 12.2 & 0.3 & 606 & 8.9 & 7.6 & 20 & 18.0 & 6.1 & 49 & 13.7 & 7.7 & 1.4 & 3.4 & 6.1 \\
\hline & & 20030812 & 0905 & 1 & 9.5 & 0.8 & 606 & 8.8 & 7.7 & 19 & 19.5 & 17.4 & 100 & 11.7 & 47.4 & $<1.0$ & 5.3 & 14.1 \\
\hline & & 20030812 & 0930 & 25 & 9.5 & 0.3 & 606 & 10.5 & 7.6 & 19 & 19.5 & 7.0 & 61 & 6.2 & 7.7 & $<1.0$ & 5.9 & 9.6 \\
\hline & & 20031020 & 1150 & 1 & 14.5 & 0.3 & 611 & 9.1 & 8.2 & 19 & 20.5 & 13.9 & 79 & 3.0 & 4.0 & $<1.0$ & 3.3 & 8.5 \\
\hline & & 20031020 & 1210 & 25 & 14.5 & 0.2 & 611 & 10.4 & 7.5 & 19 & 20.5 & 6.6 & 77 & 3.2 & 2.2 & $<1.0$ & 7.6 & 7.5 \\
\hline \multirow[t]{2}{*}{11} & Fallen Leaf Lake, south & 20020814 & 1020 & 1 & 14.6 & na & 608 & 7.4 & na & 21 & 22.0 & 19.5 & 78 & 10.0 & 3.4 & $<1.0$ & 2.8 & 11.7 \\
\hline & & 20020814 & 1030 & 25 & 14.6 & na & 608 & 9.6 & na & 20 & 22.0 & 7.5 & 92 & 7.1 & 4.4 & $<1.0$ & 2.8 & 6.9 \\
\hline 12 & Spooner Lake, south & 20020731 & 1215 & 1 & $>1.8$ & na & 596 & 9.2 & 10.7 & 387 & 25.0 & 21.8 & 346 & 12.1 & 8.4 & $<1.0$ & 15.0 & 49.9 \\
\hline 13 & Spooner Lake, east & 20020731 & 1030 & 1 & $>0.6$ & na & 596 & 7.9 & 10.2 & 392 & 24.5 & 21.3 & 816 & 10.2 & 4.2 & $<1.0$ & 30.9 & 149.8 \\
\hline \multirow[t]{12}{*}{14} & Spooner Lake near center & 20020605 & 0950 & 3.5 & 3.5 & na & 596 & 2.4 & 8.2 & 413 & 15.0 & 15.0 & 452 & 5.8 & 3.3 & $<1.0$ & 17.2 & 48.2 \\
\hline & & 20020605 & 1010 & 1 & 3.5 & na & 596 & 9.7 & 9.5 & 364 & 15.0 & 18.1 & 465 & 3.5 & 2.8 & $<1.0$ & 17.2 & 42.7 \\
\hline & & 20020731 & 0900 & 1 & 2.5 & na & 596 & 7.6 & 9.7 & 379 & 15.5 & 20.9 & na & 14.7 & 6.0 & $<1.0$ & 13.8 & 109.5 \\
\hline & & 20020731 & 0920 & 3 & 2.5 & na & 596 & 0.2 & 6.9 & 534 & 15.5 & 18.0 & 785 & 13.5 & 11.7 & $<1.0$ & 29.4 & 1,654 \\
\hline & & 20021029 & 1030 & 1 & 3.2 & 1.4 & 590 & 9.2 & 9.6 & 445 & 8.5 & 8.1 & 523 & $<3.0$ & 3.1 & 3.0 & 13.6 & 17.9 \\
\hline & & 20030528 & 1020 & 1 & 3.5 & 1.2 & 596 & 9.6 & 9.4 & 372 & 24.0 & 17.7 & 572 & 4.8 & 6.8 & 1.2 & 19.9 & 94.4 \\
\hline & & 20030528 & 1030 & 3 & 3.5 & 1.3 & 596 & 7.9 & 9.6 & 389 & 24.0 & 15.8 & 615 & 5.5 & 6.2 & 1.2 & 17.8 & 91.6 \\
\hline & & 20030813 & 0830 & 1 & $>1$ & 4.1 & 595 & 6.0 & 9.6 & 428 & 19.0 & 18.3 & 412 & $<3.0$ & 3.0 & $<1.0$ & 19.0 & 413.2 \\
\hline & & 20030813 & 0840 & 1 & $>1$ & 4.1 & 595 & 6.0 & 9.6 & 428 & 19.0 & 18.3 & 636 & 3.2 & 3.3 & $<1.0$ & 18.0 & 415.6 \\
\hline & & 20030813 & 0900 & 3 & $>1$ & 20 & 595 & 0.3 & 7.8 & 678 & 19.0 & 16.5 & 892 & 7.8 & 24.1 & $<1.0$ & 29.9 & $7,436.0$ \\
\hline & & 20031014 & 1100 & 1 & 1.5 & 5.5 & 586 & 7.7 & 8.3 & 476 & 17.0 & 10.9 & 446 & 5.8 & $<2.0$ & $<1.0$ & 14.6 & 995.2 \\
\hline & & 20031014 & 1120 & 2.5 & 1.5 & 12 & 586 & 5.4 & 8.4 & 482 & 17.0 & 10.8 & 618 & $<3.0$ & $<2.0$ & $<1.0$ & 39.5 & na \\
\hline
\end{tabular}


Appendix B. Nutrient concentrations in water samples and field data collected at study area lake sites, 2002-03-Continued

\begin{tabular}{|c|c|c|c|c|c|c|c|c|c|c|c|c|c|c|c|c|c|c|}
\hline \multirow[t]{2}{*}{$\begin{array}{c}\text { Site } \\
\text { no. } \\
\text { (see } \\
\text { fig. 2) }\end{array}$} & \multirow[t]{2}{*}{ Station name } & \multirow[t]{2}{*}{$\begin{array}{c}\text { Date } \\
\text { (yyyymmdd) }\end{array}$} & \multirow[t]{2}{*}{ Time } & $\begin{array}{l}\text { Sampl- } \\
\text { ing } \\
\text { depth }\end{array}$ & $\begin{array}{l}\text { Trans- } \\
\text { parency } \\
\text { Secchi } \\
\text { disc }\end{array}$ & \multirow{2}{*}{$\begin{array}{c}\begin{array}{c}\text { Turb- } \\
\text { idity } \\
\text { (NTU) }\end{array} \\
\text { (NTU) }\end{array}$} & \multirow{2}{*}{$\begin{array}{c}\begin{array}{c}\text { Baro- } \\
\text { metric } \\
\text { pressure }\end{array} \\
(\mathrm{mm} \mathrm{Hg})\end{array}$} & \multirow{2}{*}{$\begin{array}{c}\begin{array}{c}\text { Dissolved } \\
\text { oxygen }\end{array} \\
\text { (mg/L) }\end{array}$} & \multirow{2}{*}{$\begin{array}{c}\mathrm{pH} \\
\text { (units) }\end{array}$} & \multirow{2}{*}{$\begin{array}{c}\text { Specific } \\
\text { conduc- } \\
\text { tance } \\
(\mu S / \mathrm{cm} \\
\left.\text { at } 25^{\circ} \mathrm{C}\right)\end{array}$} & $\begin{array}{l}\text { Air } \\
\text { temp- } \\
\text { erature }\end{array}$ & $\begin{array}{l}\text { Water } \\
\text { temp- } \\
\text { erature }\end{array}$ & $\begin{array}{c}\text { Total } \\
\text { Kjeldahl } \\
\text { nitrogen } \\
\text { unfiltered }\end{array}$ & $\begin{array}{l}\text { Ammo } \\
\text { nia, } \\
\text { filtered }\end{array}$ & $\begin{array}{l}\text { Nitrate }{ }^{a} \text {, } \\
\text { filtered }\end{array}$ & $\begin{array}{l}\text { Ortho- } \\
\text { phos- } \\
\text { phate, } \\
\text { filtered }\end{array}$ & $\begin{array}{l}\text { Phos- } \\
\text { phorus, } \\
\text { unfiltered }\end{array}$ & \multirow{2}{*}{$\begin{array}{l}\text { Iron } \\
\text { (bio- } \\
\text { reac- } \\
\text { tive }), \\
\text { unfiltered } \\
\begin{array}{c}(\mu \mathrm{g} / \mathrm{L} \text { as } \\
\mathrm{Fe})\end{array} \\
\end{array}$} \\
\hline & & & & \multicolumn{2}{|c|}{ (meters) } & & & & & & \multicolumn{2}{|c|}{ (degrees Celsius) } & \multicolumn{3}{|c|}{$(\mu \mathrm{g} / \mathrm{L}$ as $\mathrm{N})$} & \multicolumn{2}{|c|}{$(\mu \mathrm{g} / \mathrm{L}$ as $P)$} & \\
\hline 15 & Spooner Lake, north & 20020731 & 1115 & 0.5 & $>0.5$ & na & 596 & 9.2 & 10.5 & 395 & 24.0 & 22.3 & na & 5.2 & 6.9 & $<1.0$ & 60.4 & 304.9 \\
\hline 16 & Spooner Lake, west & 20020731 & 1310 & 1 & $>0.8$ & na & 596 & 7.0 & 10.5 & 379 & 24.5 & 20.7 & 120 & 6.9 & 5.8 & 2.0 & 49.9 & 266.4 \\
\hline 17 & Marlette Lake, south & 20020801 & 1220 & 1 & 6.5 & na & 578 & 7.8 & na & 41 & 27.0 & 20.0 & 202 & 6.4 & 4.2 & $<1.0$ & 5.5 & 46.3 \\
\hline 18 & Marlette Lake, southeast & 20020801 & 1140 & 1 & 6.7 & na & 578 & 6.2 & na & 41 & 27.0 & 19.2 & 198 & 5.0 & 3.3 & $<1.0$ & 5.5 & 48.7 \\
\hline \multirow[t]{13}{*}{19} & Marlette Lake near center & 20020604 & 1115 & 8 & 5 & na & 578 & 2.5 & na & 36 & 18.5 & 7.9 & 254 & 13.0 & 9.5 & $<1.0$ & 20.5 & 56.4 \\
\hline & & 20020604 & 1135 & 2 & 5 & na & 578 & 3.6 & na & 36 & 18.5 & 12.9 & 87 & 11.7 & 5.0 & $<1.0$ & 11.9 & 49.3 \\
\hline & & 20020801 & 0940 & 1 & 7.5 & na & 578 & 7.4 & na & 41 & 20.0 & 19.4 & 258 & 7.1 & 5.1 & $<1.0$ & 6.4 & 49.9 \\
\hline & & 20020801 & 0955 & 11 & 7.5 & na & 578 & 0.4 & na & 46 & 20.0 & 10.5 & 243 & 28.8 & 5.1 & $<1.0$ & 17.1 & 366.6 \\
\hline & & 20021022 & 1000 & 1 & 2.4 & 3.3 & 570 & 7.4 & na & 42 & 9.0 & 9.9 & na & $<3.0$ & 3.3 & 1.0 & 10.7 & 192.2 \\
\hline & & 20021022 & 1030 & 5 & 2.4 & 2.8 & 570 & 7.2 & na & 41 & 9.0 & 9.8 & na & $<3.0$ & 4.0 & 1.2 & 12.1 & 200.0 \\
\hline & & 20030619 & 0940 & 1 & 6.5 & 0.7 & 570 & 7.6 & 7.7 & 42 & 25.0 & 16.1 & 376 & 5.4 & 4.6 & 1.0 & 7.7 & 59.0 \\
\hline & & 20030619 & 1000 & 9 & 6.5 & 1.1 & 570 & 5.6 & 7.3 & 42 & 25.0 & 5.6 & 373 & 3.7 & 4.4 & 1.0 & 12.0 & 81.4 \\
\hline & & 20030811 & 1010 & 1 & 8.3 & 0.5 & 579 & 7.0 & 7.8 & 42 & 22.5 & 18.2 & 168 & 9.1 & 4.8 & $<1.0$ & 6.2 & 46.0 \\
\hline & & 20030811 & 1030 & 9 & 8.3 & 0.8 & 579 & 8.5 & 7.8 & 43 & 22.5 & 11.2 & 280 & 11.0 & 8.4 & $<1.0$ & 10.8 & 90.7 \\
\hline & & 20031021 & 1000 & 1 & 4 & 3.2 & 581 & 8.8 & 6.7 & 43 & 16.0 & 11.4 & 367 & 14.5 & 7.3 & 1.0 & 14.3 & 296.2 \\
\hline & & 20031021 & 1010 & 1 & 4 & 1.6 & 581 & 8.8 & 6.7 & 43 & 16.0 & 11.4 & 372 & 16.9 & 6.5 & 1.0 & 14.0 & 299.2 \\
\hline & & 20031021 & 1030 & 5 & 4 & 1.8 & 581 & 8.4 & 6.4 & 43 & 16.0 & 11.4 & 323 & 15.6 & 6.6 & 1.0 & 17.4 & 303.0 \\
\hline 20 & Marlette Lake, east & 20020801 & 1115 & 1 & 7.8 & na & 578 & 7.2 & na & 41 & 26.0 & 19.7 & 176 & 8.1 & 5.8 & $<1.0$ & 5.5 & 42.5 \\
\hline 21 & Marlette Lake, north & 20020801 & 1040 & 1 & 8.1 & na & 578 & 7.3 & na & 41 & 22.0 & 19.4 & 143 & 7.1 & 4.5 & $<1.0$ & 5.5 & 46.6 \\
\hline
\end{tabular}

${ }^{\mathrm{a}}$ Nitrate results include all oxidized forms of nitrogen (nitrate plus nitrite) as determined by the Hydrazine method. 
Appendix C. Nutrient concentrations in water samples and field data collected at study area stream sites, 2002-03

[Abbreviations: --, no data; ${ }^{\circ} \mathrm{C}$, degrees Celsius; \%, percent; mg/L, milligrams per liter; mm, millimeters; $\mu \mathrm{g} / \mathrm{L}$, micrograms per liter; Hg, mercury; <, less than; NTU, nephelometric turbidity units; $\mu \mathrm{S} / \mathrm{cm}$, microsiemens per centimeter]

\begin{tabular}{|c|c|c|c|c|c|c|c|c|c|c|c|c|c|c|c|c|c|c|}
\hline $\begin{array}{l}\text { Site } \\
\text { no. } \\
\text { (see } \\
\text { fig. 2) }\end{array}$ & Station name & $\begin{array}{c}\text { Date } \\
\text { (yyyymmdd) }\end{array}$ & Time & $\begin{array}{l}\text { Baro- } \\
\text { metric } \\
\text { pressure } \\
(\mathrm{mm} \mathrm{Hg})\end{array}$ & $\begin{array}{c}\text { Dis- } \\
\text { solved } \\
\text { oxy- } \\
\text { gen } \\
(\mathrm{mg} / \mathrm{L})\end{array}$ & $\begin{array}{c}\mathrm{pH} \\
\text { (units) }\end{array}$ & $\begin{array}{l}\text { Specific } \\
\text { conduc- } \\
\text { tance } \\
(\mu \mathrm{S} / \mathrm{cm} \\
\left.\text { at } 25^{\circ} \mathrm{C}\right) \\
\end{array}$ & $\begin{array}{c}\text { Air } \\
\text { temp- } \\
\text { erature } \\
\left({ }^{\circ} \mathrm{C}\right) \\
\end{array}$ & $\begin{array}{l}\text { Water } \\
\text { temp- } \\
\text { erature } \\
\left({ }^{\circ} \mathrm{C}\right)\end{array}$ & $\begin{array}{l}\text { Turb- } \\
\text { idity } \\
\text { (NTU) }\end{array}$ & $\begin{array}{c}\text { Sus- } \\
\text { pended } \\
\text { sedi- } \\
\text { ment } \\
\text { finer } \\
\text { than } \\
0.063 \\
\mathrm{~mm} \\
(\%)\end{array}$ & $\begin{array}{l} \\
\text { Sus- } \\
\text { pended } \\
\text { sedi- } \\
\text { ment } \\
\text { concen- } \\
\text { tration } \\
\text { (mg/L) }\end{array}$ & $\begin{array}{c}\text { Total } \\
\text { Kjeldahl }\end{array}$ & $\begin{array}{c}\begin{array}{c}\text { Ammonia, } \\
\text { filtered }\end{array} \\
(\mu \mathrm{g} / \mathrm{L} \text { as } \mathrm{N})\end{array}$ & $\begin{array}{l}\text { Nitrate }^{a}, \\
\text { filtered }\end{array}$ & $\begin{array}{l}\begin{array}{c}\text { Ortho- } \\
\text { phos- } \\
\text { phate, } \\
\text { filtered } \\
(\mu \mathrm{g} / 1\end{array}\end{array}$ & $\begin{array}{c}\text { Phos- } \\
\text { phosus, } \\
\text { unfiltered } \\
\text { L as P) }\end{array}$ & $\begin{array}{c}\text { Iron } \\
\text { (biore- } \\
\text { active), } \\
\text { unfiltered } \\
(\mu \mathrm{g} / \mathrm{L} \text { as } \mathrm{Fe})\end{array}$ \\
\hline 22 & $\begin{array}{l}\text { Taylor Creek near } \\
\text { Camp Richardson, CA }\end{array}$ & $\begin{array}{l}20020603 \\
20020603 \\
20020802 \\
20021023 \\
20030618 \\
20030814 \\
20031015\end{array}$ & $\begin{array}{l}1440 \\
1441 \\
1250 \\
1410 \\
1200 \\
1040 \\
1110\end{array}$ & $\begin{array}{l}606 \\
606 \\
605 \\
603 \\
604 \\
610 \\
606\end{array}$ & $\begin{array}{l}7 \\
7 \\
7 \\
8 \\
8 \\
7 \\
8\end{array}$ & $\begin{array}{l}-- \\
-- \\
-- \\
7 \\
8 \\
8 \\
7\end{array}$ & $\begin{array}{l}19 \\
19 \\
22 \\
23 \\
20 \\
22 \\
20\end{array}$ & $\begin{array}{l}25 \\
25 \\
22 \\
11 \\
25 \\
25 \\
18\end{array}$ & $\begin{array}{l}15 \\
15 \\
23 \\
11 \\
19 \\
17 \\
12\end{array}$ & $\begin{array}{l}-- \\
- \\
-- \\
1 \\
0 \\
0 \\
1\end{array}$ & $\begin{array}{c}-- \\
-- \\
25 \\
43 \\
-- \\
56\end{array}$ & $\begin{array}{l}-- \\
-- \\
1 \\
1 \\
-- \\
- \\
1\end{array}$ & $\begin{array}{r}44 \\
126 \\
96 \\
264 \\
-- \\
-- \\
80\end{array}$ & $\begin{array}{r}9 \\
5 \\
8 \\
99 \\
-- \\
-- \\
3\end{array}$ & $\begin{array}{r}3 \\
2 \\
10 \\
30 \\
-- \\
-- \\
3\end{array}$ & $\begin{array}{l}<1.0 \\
<1.0 \\
<1.0 \\
14 \\
-- \\
-- \\
<1.0\end{array}$ & $\begin{array}{r}4 \\
4 \\
9 \\
30 \\
-- \\
-- \\
6\end{array}$ & $\begin{array}{r}76 \\
69 \\
36 \\
27 \\
-- \\
-- \\
25\end{array}$ \\
\hline 23 & $\begin{array}{c}\text { Echo Lakes Channel } \\
\text { between Upper and } \\
\text { Lower Lakes, } \mathrm{CA}^{\mathrm{b}}\end{array}$ & 20020822 & 1040 & 585 & 7 & -- & 7 & 23 & 16 & -- & -- & -- & 126 & 7 & 6 & $<1.0$ & 4 & 26 \\
\hline 24 & $\begin{array}{l}\text { Echo Creek at outlet } \\
\text { near Phillips, CA }\end{array}$ & $\begin{array}{l}20020606 \\
20020802 \\
20020802 \\
20021023 \\
20021023 \\
20030617 \\
20030814 \\
20031015\end{array}$ & $\begin{array}{l}0935 \\
1010 \\
1020 \\
1100 \\
1105 \\
1430 \\
0900 \\
0930\end{array}$ & $\begin{array}{l}585 \\
585 \\
585 \\
582 \\
582 \\
583 \\
587 \\
584\end{array}$ & $\begin{array}{l}8 \\
6 \\
6 \\
8 \\
8 \\
9 \\
7 \\
7\end{array}$ & $\begin{array}{r}-- \\
-- \\
- \\
7 \\
7 \\
9 \\
10 \\
8\end{array}$ & $\begin{array}{r}6 \\
48 \\
48 \\
8 \\
8 \\
8 \\
31 \\
17\end{array}$ & $\begin{array}{l}18 \\
19 \\
19 \\
10 \\
10 \\
23 \\
21 \\
11\end{array}$ & $\begin{array}{r}12 \\
19 \\
19 \\
11 \\
11 \\
16 \\
16 \\
9\end{array}$ & $\begin{array}{l}-- \\
-- \\
-- \\
0 \\
0 \\
2 \\
0 \\
0\end{array}$ & $\begin{array}{l}-- \\
-- \\
42 \\
-- \\
75 \\
-- \\
58 \\
67 \\
50\end{array}$ & $\begin{array}{c}-- \\
-- \\
2 \\
-- \\
0 \\
-- \\
2 \\
1 \\
0\end{array}$ & $\begin{array}{r}185 \\
119 \\
192 \\
91 \\
123 \\
112 \\
101 \\
86\end{array}$ & $\begin{array}{c}5 \\
16 \\
15 \\
4 \\
3 \\
<3.0 \\
11 \\
5\end{array}$ & $\begin{array}{r}8 \\
14 \\
12 \\
2 \\
5 \\
6 \\
12 \\
10\end{array}$ & $\begin{array}{c}<1.0 \\
2 \\
2 \\
1 \\
1 \\
2 \\
1 \\
<1.0\end{array}$ & $\begin{array}{r}3 \\
10 \\
10 \\
5 \\
5 \\
13 \\
9 \\
4\end{array}$ & $\begin{array}{l}66 \\
96 \\
89 \\
19 \\
17 \\
43 \\
43 \\
39\end{array}$ \\
\hline 25 & $\begin{array}{l}\text { Marlette Creek near } \\
\text { Carson City, NV }\end{array}$ & $\begin{array}{l}20020604 \\
20020801 \\
20021022 \\
20030619 \\
20030811 \\
20031021 \\
20031021\end{array}$ & $\begin{array}{l}1340 \\
1320 \\
1250 \\
1140 \\
1120 \\
1100 \\
1110\end{array}$ & $\begin{array}{l}578 \\
578 \\
570 \\
570 \\
579 \\
581 \\
581\end{array}$ & $\begin{array}{l}5 \\
7 \\
7 \\
7 \\
8 \\
7 \\
7\end{array}$ & $\begin{array}{l}-- \\
-- \\
7 \\
6 \\
8 \\
8 \\
8\end{array}$ & $\begin{array}{l}37 \\
52 \\
53 \\
48 \\
54 \\
55 \\
55\end{array}$ & $\begin{array}{r}-- \\
23 \\
8 \\
15 \\
23 \\
23 \\
23\end{array}$ & $\begin{array}{r}15 \\
11 \\
8 \\
9 \\
9 \\
9 \\
9\end{array}$ & $\begin{array}{l}-- \\
-- \\
3 \\
7 \\
3 \\
1 \\
1\end{array}$ & $\begin{array}{l}-- \\
74 \\
83 \\
73 \\
-- \\
50 \\
--\end{array}$ & $\begin{array}{r}-- \\
14 \\
1 \\
5 \\
-- \\
2 \\
--\end{array}$ & $\begin{array}{r}593 \\
349 \\
1,580 \\
261 \\
119 \\
117 \\
165\end{array}$ & $\begin{array}{l}10 \\
14 \\
<3.0 \\
5 \\
10 \\
<3.0 \\
<3.0\end{array}$ & $\begin{array}{l}15 \\
65 \\
36 \\
72 \\
64 \\
38 \\
38\end{array}$ & $\begin{array}{l}3 \\
3 \\
4 \\
5 \\
3 \\
2 \\
3\end{array}$ & $\begin{array}{r}14 \\
78 \\
20 \\
39 \\
19 \\
8 \\
9\end{array}$ & $\begin{array}{r}69 \\
2,247 \\
134 \\
1,034 \\
572 \\
284 \\
280\end{array}$ \\
\hline
\end{tabular}

${ }^{\mathrm{a}}$ Nitrate results include all oxidized forms of nitrogen (nitrate plus nitrite) as determined by the Hydrazine method.

${ }^{b}$ Echo Lakes Channel site was not included in statistical summaries of data for this report. 
Appendix D. Nitrate concentrations determined using the Hydrazine method with pyrophosphate for samples collected from study area lake and stream sites after May 2003 [Abbreviation: $\mu \mathrm{g} / \mathrm{L}$, micrograms per liter]

\begin{tabular}{|c|c|c|c|c|c|c|c|c|c|}
\hline $\begin{array}{l}\text { Site no. } \\
\text { (see } \\
\text { fig. 2) }\end{array}$ & Station name & $\begin{array}{c}\text { Date } \\
\text { (yyyymmdd) }\end{array}$ & Time & $\begin{array}{c}\text { Nitrate }^{\mathrm{a}}, \\
\text { filtered } \\
(\mu \mathrm{g} / \mathrm{L})\end{array}$ & $\begin{array}{l}\text { Site no. } \\
\text { (see } \\
\text { fig. 2) }\end{array}$ & Station name & $\begin{array}{c}\text { Date } \\
\text { (yyyymmdd) }\end{array}$ & Time & $\begin{array}{r}\text { Nitrate }^{a} \\
\text { filtered } \\
(\mu \mathrm{g} / \mathrm{L})\end{array}$ \\
\hline \multirow[t]{7}{*}{2} & Lower Echo Lake near center & 20030617 & 1020 & 10.7 & 22 & Taylor Creek & 20030618 & 1200 & 10.7 \\
\hline & & 20030617 & 1050 & 6.5 & & & 20030814 & 1040 & 11.3 \\
\hline & & 20030819 & 1015 & 3.6 & & & 20031015 & 1110 & 4.5 \\
\hline & & 20030819 & 1030 & 2.5 & 24 & Echo Creek & 20030603 & 1430 & 6.5 \\
\hline & & 20031020 & 0930 & 8.1 & & & 20030814 & 0900 & 12.2 \\
\hline & & 20031020 & 0945 & 2.5 & & & 20031015 & 0930 & 11.3 \\
\hline & & 20031022 & 1008 & 3.4 & 25 & Marlette Creek & 20030619 & 1140 & 90.6 \\
\hline \multirow[t]{4}{*}{5} & Upper Echo Lake near center & 20030617 & 1150 & 21.5 & & & 20030811 & 1120 & 82.9 \\
\hline & & 20030617 & 1215 & 18.6 & & & 20031021 & 1100 & 43.2 \\
\hline & & 20030819 & 1110 & 2.3 & & & 20031021 & 1110 & 43.2 \\
\hline & & 20030819 & 1130 & 2.5 & & & & & \\
\hline \multirow[t]{6}{*}{10} & Fallen Leaf Lake near center & 20030529 & 0945 & 2.6 & & & & & \\
\hline & & 20030529 & 1000 & 7.5 & & & & & \\
\hline & & 20030812 & 0905 & 54.8 & & & & & \\
\hline & & 20030812 & 0930 & 7.4 & & & & & \\
\hline & & 20031020 & 1150 & 5.1 & & & & & \\
\hline & & 20031020 & 1210 & 2.5 & & & & & \\
\hline \multirow[t]{7}{*}{14} & Spooner Lake near center & 20030528 & 1020 & 6.9 & & & & & \\
\hline & & 20030528 & 1030 & 6.9 & & & & & \\
\hline & & 20030813 & 0830 & 2.3 & & & & & \\
\hline & & 20030813 & 0840 & 2.5 & & & & & \\
\hline & & 20030813 & 0900 & 6.7 & & & & & \\
\hline & & 20031014 & 1100 & 1.9 & & & & & \\
\hline & & 20031014 & 1120 & 1.9 & & & & & \\
\hline \multirow[t]{7}{*}{19} & Marlette Lake near center & 20030619 & 0940 & 5.1 & & & & & \\
\hline & & 20030619 & 1000 & 4.7 & & & & & \\
\hline & & 20030811 & 1010 & 4.7 & & & & & \\
\hline & & 20030811 & 1030 & 9.6 & & & & & \\
\hline & & 20031021 & 1000 & 8.7 & & & & & \\
\hline & & 20031021 & 1010 & 7.7 & & & & & \\
\hline & & 20031021 & 1030 & 8.1 & & & & & \\
\hline
\end{tabular}

${ }^{\mathrm{a} N i t r a t e}$ results include all oxidized forms of nitrogen (nitrate plus nitrite). 